\title{
Sediment source fingerprinting: benchmarking recent outputs, remaining challenges and emerging themes
}

\author{
Adrian L. Collins ${ }^{1}$ (D) $\cdot$ Martin Blackwell ${ }^{1}$ - Pascal Boeckx ${ }^{2} \cdot$ Charlotte-Anne Chivers $^{1,3} \cdot$ Monica Emelko $^{4}$. \\ Olivier Evrard ${ }^{5}$ • Ian Foster ${ }^{6}$ - Allen Gellis ${ }^{7}$. Hamid Gholami ${ }^{8}$ - Steve Granger ${ }^{1}$ - Paul Harris ${ }^{1}$ - Arthur J. Horowitz ${ }^{9}$. \\ J. Patrick Laceby ${ }^{10} \cdot$ Nuria Martinez-Carreras $^{11} \cdot$ Jean Minella ${ }^{12} \cdot$ Lisa Mol $^{13} \cdot$ Kazem Nosrati $^{14} \cdot$ Simon Pulley ${ }^{1}$. \\ Uldis Silins ${ }^{15} \cdot$ Yuri Jacques da Silva ${ }^{16} \cdot$ Micheal Stone $^{17} \cdot$ Tales Tiecher $^{18} \cdot$ Hari Ram Upadhayay ${ }^{1} \cdot$ Yusheng Zhang $^{1}$
}

Received: 25 February 2020 / Accepted: 13 August 2020 / Published online: 16 September 2020

(C) The Author(s) 2020

\begin{abstract}
Purpose This review of sediment source fingerprinting assesses the current state-of-the-art, remaining challenges and emerging themes. It combines inputs from international scientists either with track records in the approach or with expertise relevant to progressing the science.

Methods Web of Science and Google Scholar were used to review published papers spanning the period 2013-2019, inclusive, to confirm publication trends in quantities of papers by study area country and the types of tracers used. The most recent (20182019, inclusive) papers were also benchmarked using a methodological decision-tree published in 2017.

Scope Areas requiring further research and international consensus on methodological detail are reviewed, and these comprise spatial variability in tracers and corresponding sampling implications for end-members, temporal variability in tracers and sampling implications for end-members and target sediment, tracer conservation and knowledge-based pre-selection, the physico-chemical basis for source discrimination and dissemination of fingerprinting results to stakeholders. Emerging themes are also discussed: novel tracers, concentration-dependence for biomarkers, combining sediment fingerprinting and age-dating, applications to sediment-bound pollutants, incorporation of supportive spatial information to augment discrimination and modelling, aeolian sediment source fingerprinting, integration with process-based models and development of open-access software tools for data processing.

Conclusions The popularity of sediment source fingerprinting continues on an upward trend globally, but with this growth comes issues surrounding lack of standardisation and procedural diversity. Nonetheless, the last 2 years have also evidenced growing uptake of critical requirements for robust applications and this review is intended to signpost investigators, both old and new, towards these benchmarks and remaining research challenges for, and emerging options for different applications of, the fingerprinting approach.
\end{abstract}

Keywords Fingerprinting approach $\cdot$ Tracers $\cdot$ Biomarkers $\cdot$ Sediment-age dating $\cdot$ Weathering indices

\section{Introduction}

Accelerated soil erosion and sediment delivery are widely recognized as globally pervasive threats to ecosystem services essential for sustainable livelihoods and development

Editorial Responsibility: Alexander Koiter

Adrian L. Collins

adrian.collins@rothamsted.ac.uk

Extended author information available on the last page of the article
(Pimentel 2006; Montgomery 2007; Maetens et al. 2012; Borrelli et al. 2017; Garcia-Ruiz et al. 2017). Targeted governance and management of soil and water resources are, as a result, policy priorities worldwide (Montanarella 2015; Wu et al. 2020). Well-designed policies and control strategies for protecting soil and water resources are dependent on reliable and scale-appropriate information on the key sources of the sediment problem which is manifested in the form of both onsite and off-site consequences. With respect to scale, the river catchment continues to be seen as a fundamental landscape unit for framing both the scientific exploration of sediment systems and for devising meaningful management strategies 
within the context of natural hydrological hierarchies. Spatial scales for sediment sourcing studies have ranged from hillslopes to large $\left(>10,000 \mathrm{~km}^{2}\right)$ river basins. Fine-grained sediment $(<2 \mathrm{~mm}$, but frequently $<63 \mu \mathrm{m}$ or finer in most fingerprinting studies) remains the focus of much attention, both scientifically and managerially, since finer particulates are an important vector for the transfer, dispersal and fate of nutrients and contaminants, whilst also causing detrimental impacts on all aquatic trophic levels including diatoms (Chen et al. 2019), macroinvertebrates (Gieswein et al. 2019), macrophytes (Jones et al. 2012) and fish (Kemp et al. 2011)

The most widely used direct approach for investigating catchment sediment sources is sediment fingerprinting (Collins and Walling 2004; Walling 2005; Krishnappan et al. 2009; Walling 2013b; Miller et al. 2015; Owens et al. 2016). Fundamentally, this approach is founded on the collection of target sediment and catchment source material samples and comparison of their properties or composite fingerprints to estimate the relative importance of different upstream sources. Since emerging in the 1970s through the work of Klages and Hsieh (1975), Wall and Wilding (1976) and Walling et al. (1979), both uptake and the scope of sediment source fingerprinting studies have increased dramatically (Walling et al. 2003; Haddadchi et al. 2013; Owens et al. 2016; Collins et al. 2017). Key and well-documented stages in the evolution and continued development of sediment source fingerprinting procedures over the past 40 years include the transgression from single component to composite (i.e. multiple property or tracer) signatures for source discrimination, adoption of frequentist and, more latterly, Bayesian un-mixing models for source apportionment and explicit treatment and estimation of sampling, analytical and predictive uncertainties.

More recently, however, many of the key assumptions underpinning the fingerprinting approach have been revisited, tested and challenged alongside the increased uptake for more general case study investigations. One outcome of these rapidly growing research efforts has been an expansion in both the complexity and the methodological diversity of the procedures reported in source fingerprinting studies. Such divergence in methodological detail has arisen due to the growing number of research groups working on the approach and despite the publication of some generic decision trees (Lees 1999; Foster and Lees 2000; Walling and Collins 2000; Walling et al. 2003; Collins and Walling 2004; Walling et al. 2006) throughout the period of expansion in uptake by the user community. In turn, the divergence in the methodological steps in fingerprinting operational procedures reported in the international literature raises doubts and uncertainties among new or early adopters and continues to challenge more strategic or widespread uptake of the approach as a standard tool for scientific or management goals (Mukundan et al.
2012; Collins et al. 2017). The absence of standardisation clearly reflects various drivers including scientific curiosity or opinion, available access to and budgets for field and laboratory resources and site-specific challenges due to natural and anthropogenic factors such as geology and soils or land use.

In the context of the above, this paper reviews the status quo for sediment source fingerprinting using inputs from both established investigators and independent researchers with skills or expertise considered to be highly pertinent to addressing ongoing challenges in refining and standardising operational procedures. The following sections report the continued growth of published outputs over the past 7 years, benchmark published studies since the release of a detailed methodological decision-tree at the end of 2017 (Collins et al. 2017), review outstanding issues in need of further research and scientific consensus and point to newly emerging themes in sediment fingerprinting research and applications.

\section{The status quo}

\subsection{The continued global growth in published papers using sediment source fingerprinting}

Following on from Walling (2013b), a literature search using Web of Science and Google Scholar and the search terms 'sediment' and 'source apportionment', 'sediment' and 'fingerprinting', 'sediment' and 'provenance' and 'sediment', 'source' and 'contribution', suggests that the publication of papers during the period 2013-2019, inclusive, has continued to show a general upward trend, with an annual average of 31 papers (Fig. 1a). Closer examination of the papers assembled by the literature search (Fig. 1b) suggests that the application of geochemical signatures remains dominant, whereas the use of fallout radionuclides has declined and applications of compound-specific stable isotopes increased. Another noteworthy trend is that the application of composite signatures combining more than one type of tracer has increased during 2018-2019. Figure 2 suggests that of the studies published between 2013 and 2019, most were undertaken in the USA, UK and China, closely followed by Australia, Iran, Brazil, Spain and France.

\subsection{Benchmarking recent papers against critical state- of-the-art methodological steps}

There is significant variability (Fig. 3) among the finer details of the procedures reported by international studies since the publication of a decision-tree outlining key methodological steps by Collins et al. (2017). Clearly, it takes time for recommendations to be operationalized in the international literature, but benchmarking can be used to highlight the lack of 
a)

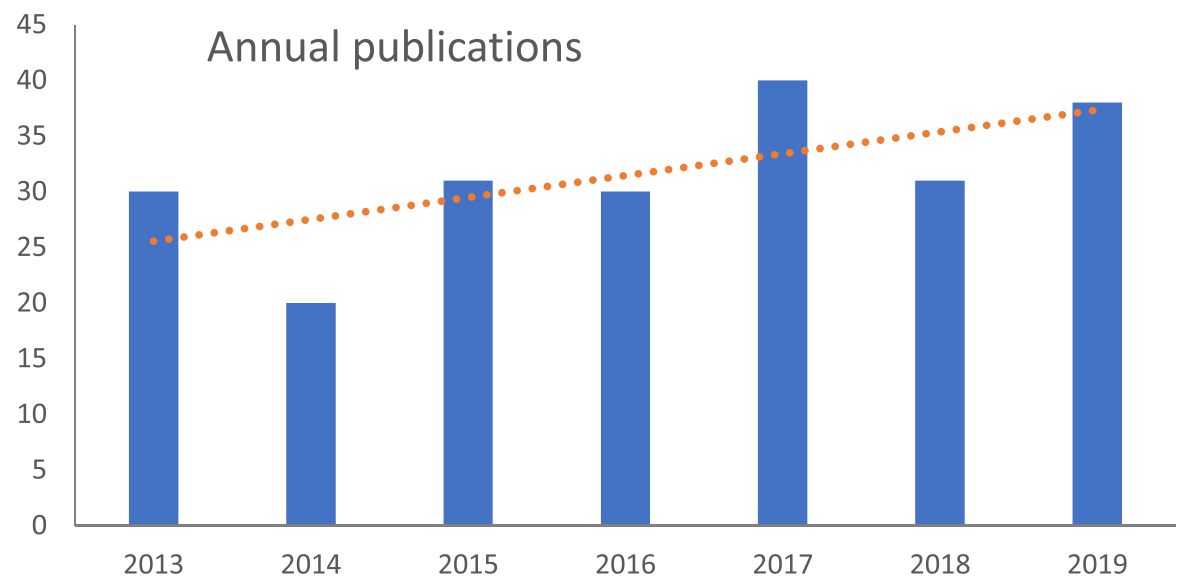

b)

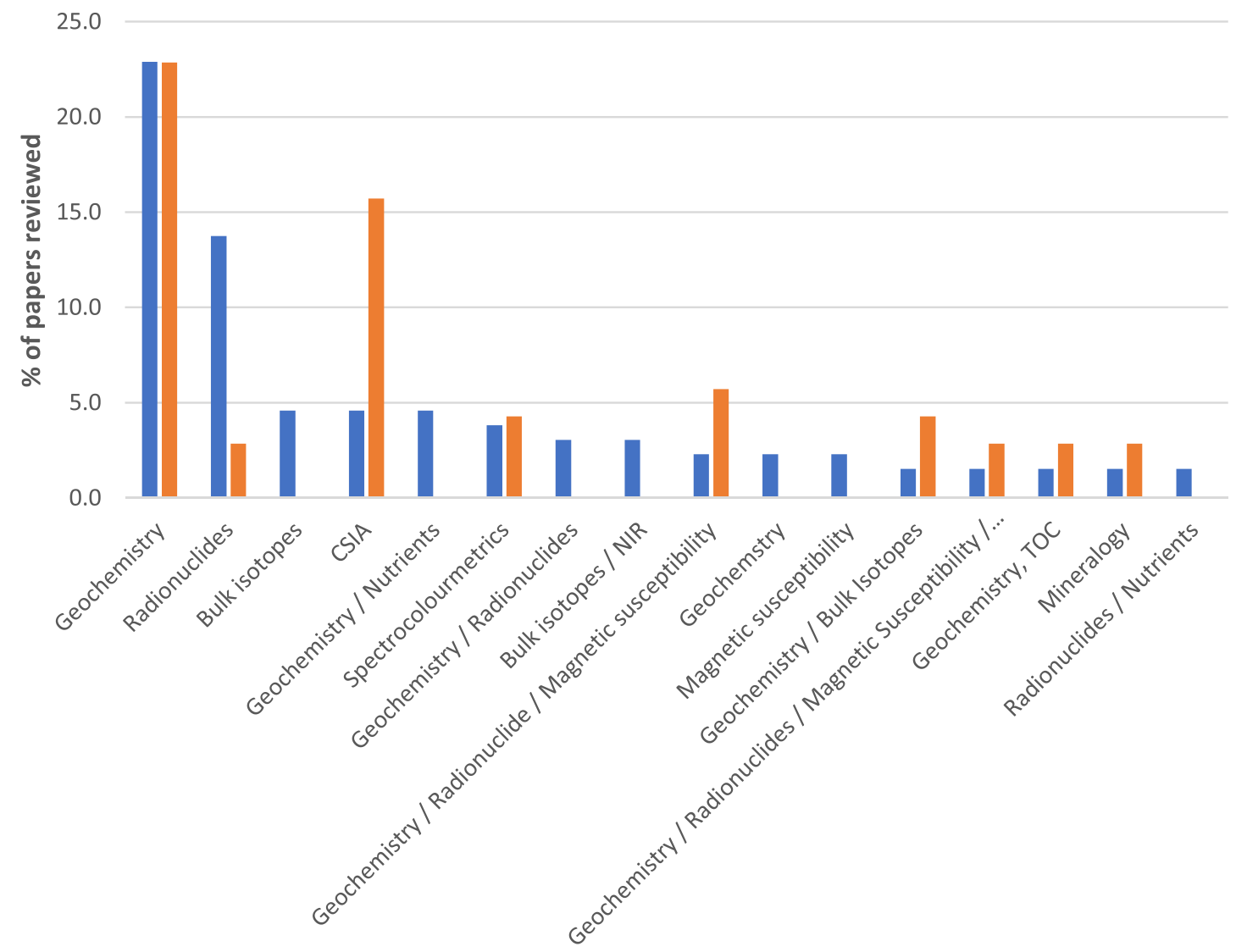

Composite signatures

[ 2013 - 2017 -2018-2019

Fig. 1 a Published papers reporting the use of fingerprinting each year between 2013 and 2019, inclusive (trend not statistically significant). b A breakdown of the composite signatures used by papers published during 2013-2017 ( $n=131$ papers) and 2018-2019 ( $n=71$ papers) 


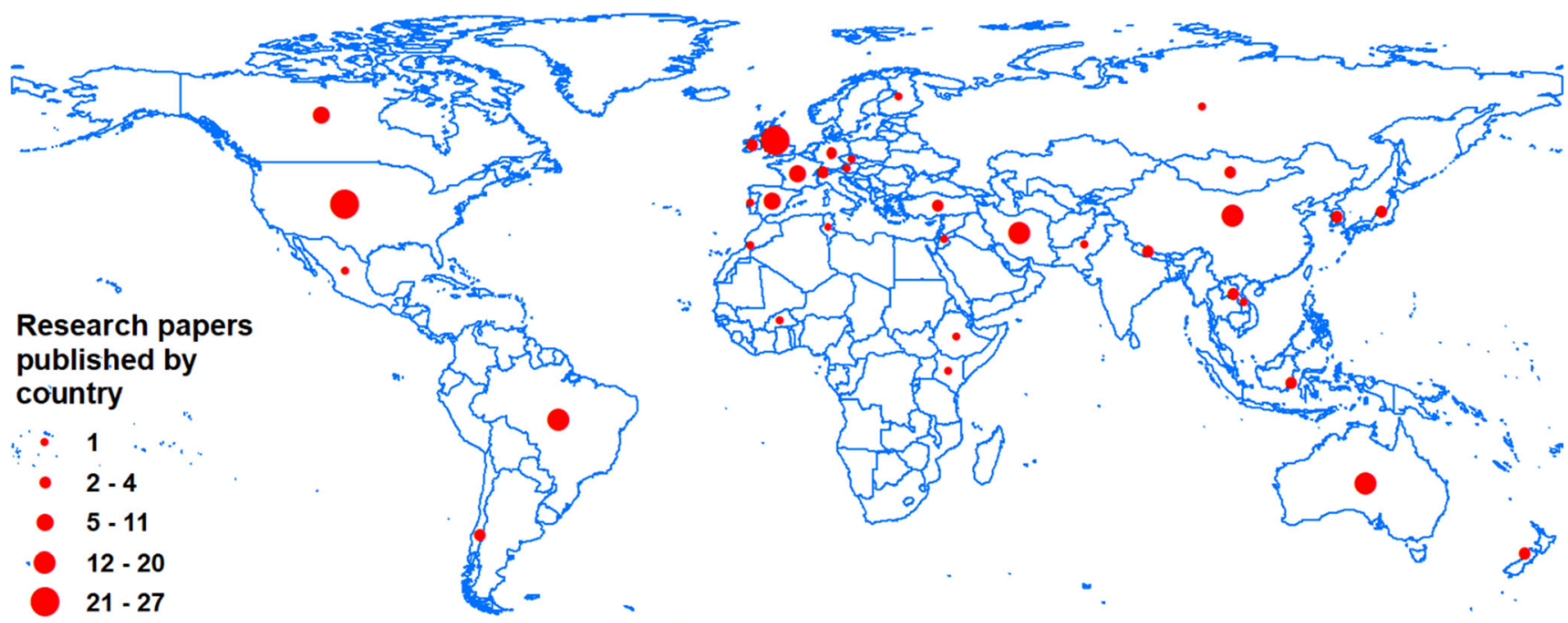

Fig. 2 The number of fingerprinting papers published between 2013 and 2019, inclusive, using the countries for the study sites

standardisation and critical gaps in some published studies. Many papers published during 2018 and 2019 do not implement essential parts of the methodology raising the possibility of major uncertainties associated with study outputs. Given the latter, a lack of standardisation among international studies risks undermining the credibility of the fingerprinting approach in the longer term. This sub-section therefore briefly revisits fundamental steps in the state-of-the-art methodology to guide authors using sediment source fingerprinting or reviewers of such work. Tang et al. (2019) recently benchmarked sediment source fingerprinting papers arising from China, and here, we extend such analysis internationally.

Sediment source classification is a critical step in the application of fingerprinting since it is used to structure the field sampling of potential sources. It is common practice to utilize a priori sources groups based upon land use. However, individual tracers might be more strongly spatially controlled by other factors such as geology. In this situation, within-source group tracer variability will likely be high resulting in more uncertain un-mixing model outputs (Pulley et al. 2015a; Pulley and Rowntree 2016). The use of multiple source group classifications can result in a greater spatial resolution of sediment provenance estimates increasing the utility of results. It should also be considered if the selected tracers can discriminate between the a priori sources or if two or more sources should be combined. In the most recent (2018-2019) publications reviewed, it remains uncommon (only $22 \%$ ) for alternative source group classifications to be considered after tracers have been measured. Source groups selected a priori may be perfectly acceptable, but the exploration of multiple groupings can improve robustness.

Once source samples have been retrieved from the field, tracers for the identification of robust composite signatures need to be selected and analysed. Here, the physical basis for the discrimination of the sampled source groups is an important consideration, but only $39 \%$ of the $2018-2019$ publications report some explicit assessment of this basis. Alongside the selection of the tracers, critical decisions need to be made for particle size. This has been shown to exert a strong control on source and target sediment tracer concentrations and therefore represents a major potential source of uncertainty. The decision as to which particle size range to use is commonly guided by three considerations: firstly, the primary particle size of the material being transported; secondly, the relationships between particle size and tracer concentrations (e.g. Gellis and Sanisaca 2018); and, thirdly, the time and resource requirements for sample preparation. It remains most common (59\% of 2018-2019 publications) to use the $<63 \mu \mathrm{m}$ fraction on the basis that it is generally representative of what is transported by rivers. Sample preparation using this fraction is also faster when compared with finer sizes which may require wet sieving or elutriation. However, multiple studies have shown considerable variability in tracer concentrations within this particle size range. As a result, this practice may no longer be sufficiently robust to give confidence that outputs are not heavily affected by differences in particle size between sources and target sediments. The use of narrower (e.g. < $10 \mu \mathrm{m}$ ) size ranges ( $10 \%$ of $2018-2019$ publications) is likely to further minimize the potential for these uncertainties. It is best practice to measure the particle size distribution of the sources and target sediments and present a comparison so it can be judged if there are likely to be significant differences between the two (29\% of 2018-2019 publications). Studies which fail to fractionate or use broad particle size ranges such as $<2 \mathrm{~mm}$ (24\% of 2018-2019 publications) may not be reliable unless combined with a robust analysis of particle size effects, and therefore, caution should be exercised before their publication. It is highly unlikely that the properties of sands and silts/clays will be comparable, and sediment particle size is likely to change during sediment transport producing 
a)

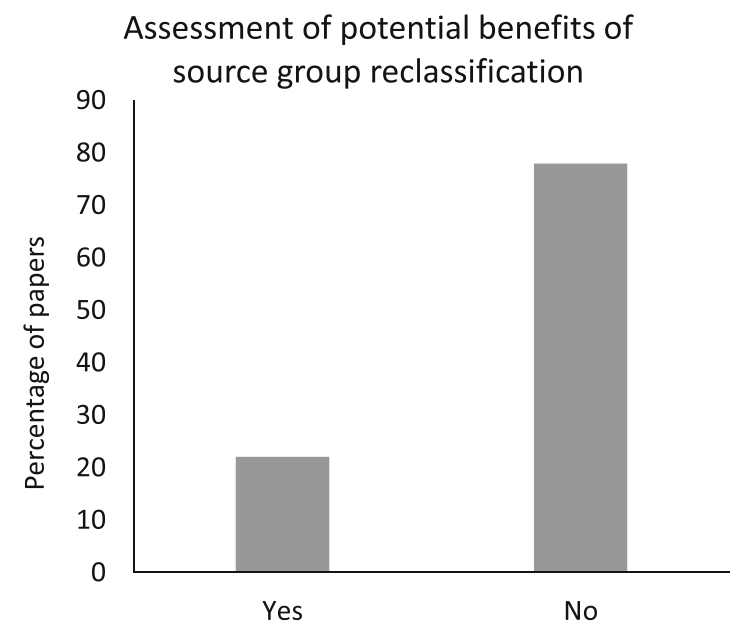

b)

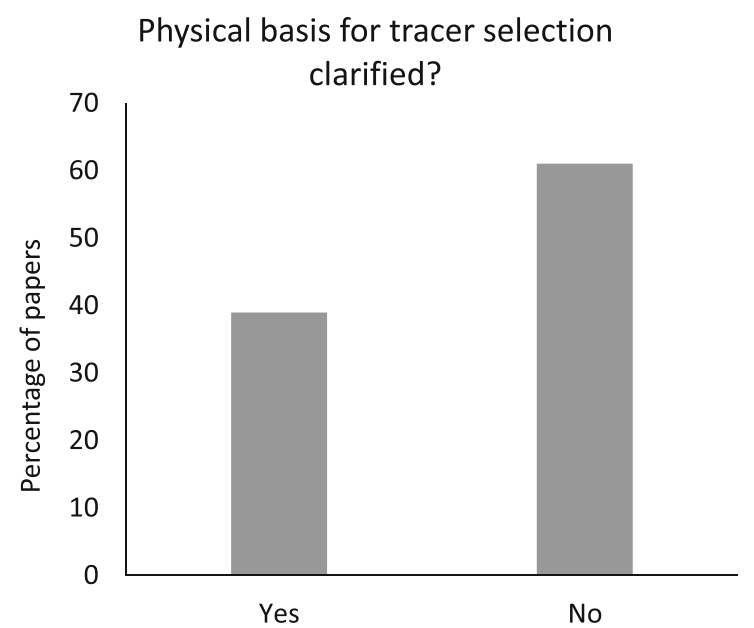

c)

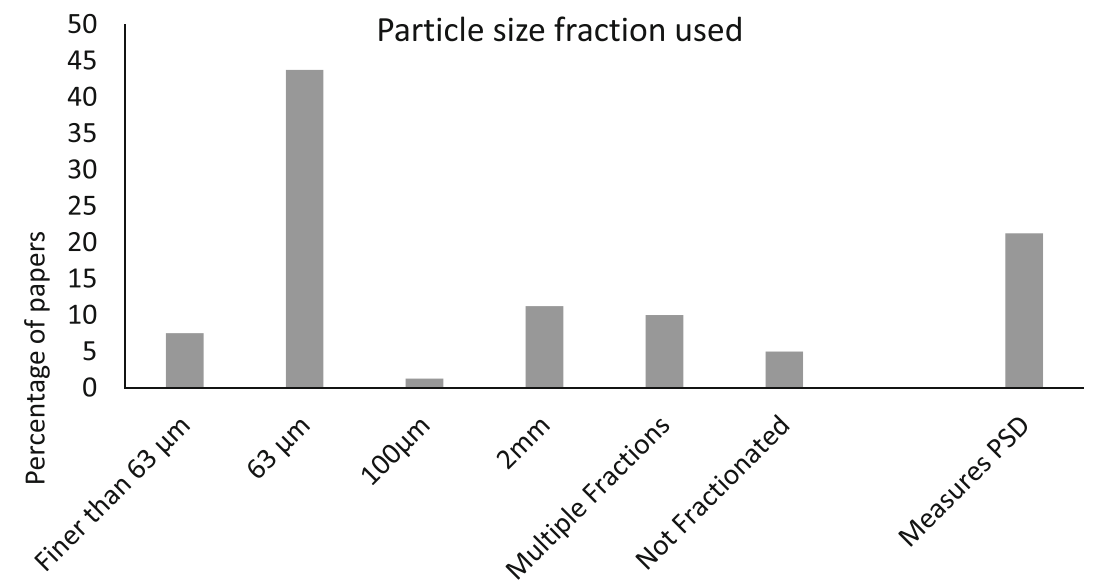

Fig. 3 Benchmarking of recent (2018 and 2019, inclusive) papers for use of critical methodological steps 
d)

\section{Conservative tests used}

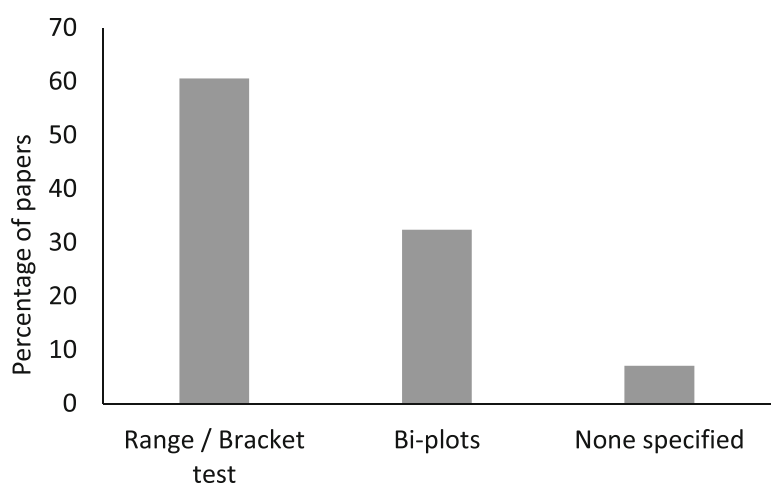

e)

The use of multiple composite fingerprints

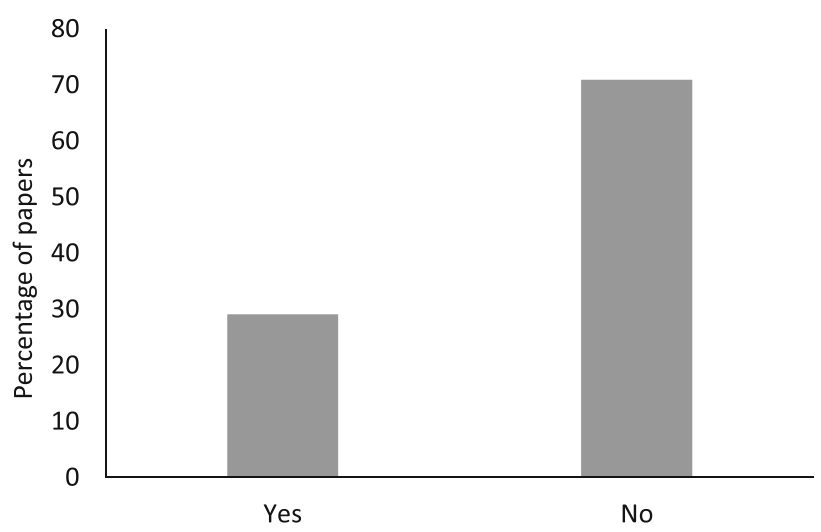

f)

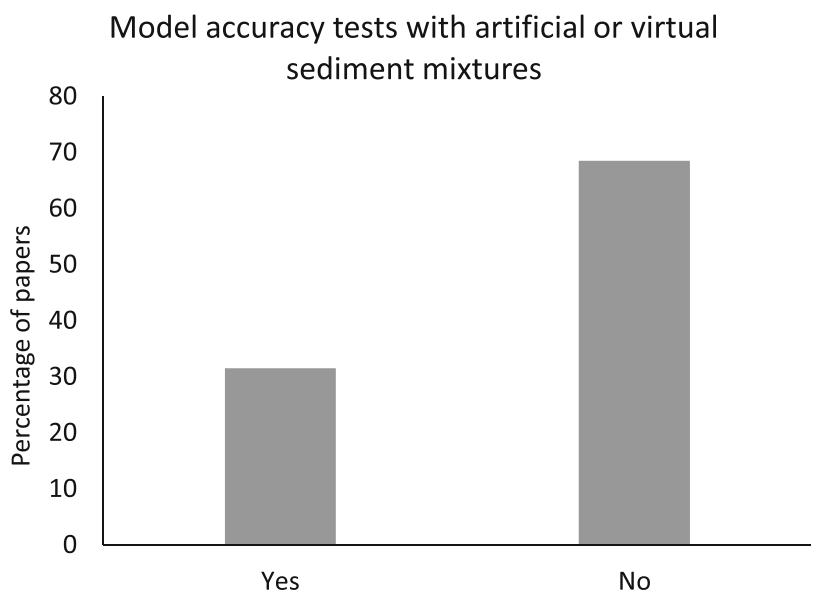

Fig. 3 continued.

outputs which are primarily controlled by changes in sediment particle size rather than sediment source.
In addition to being robust discriminators, the individual properties comprising composite signatures should exhibit conservative behaviour. A conservative tracer is often determined using simple bracketing tests (Foster and Lees 2000; Wilkinson et al. 2013). Various approaches have been used to help end-users visualize this component of fingerprinting procedures (e.g. boxplot-based range test (Blake et al. 2012), point-in-polygon (Brandt et al. 2018; Bravo-Linares et al. 2018), point-in-ellipsoid (Upadhayay et al. 2018b)). Simple boxplots of source and target sediment sample tracer values provide easily understandable qualitative information on the potential transformation of the tracers being used. However, the standard range or bracket test approaches are valid for individual tracers. In contrast, the point-in-polygon approach quantitatively enables end-users to evaluate whether target sediment samples are within or outside the end-member polygon for up to three-tracer systems (Smith et al. 2013b). More recently, Upadhayay et al. (2018b) applied the point-inellipsoid approach that can deal with multiple tracers simultaneously. This involves the transformation of the ellipsoid for the source and target sediment tracers into circles and overlapping these circles to provide qualitative information as to whether each sediment sample is in or out of the mixing ellipsoid (Jackson 2016).

The assessment of tracer non-conservatism (92\% of 2018 2019 publications) is conducted conventionally using a range test. The basic test, as noted above, determines if the tracer concentrations of the sediments fall within the maximum and minimum of the sources (Foster and Lees 2000). A stricter version of this test uses the mean tracer concentrations of the source groups and target sediments (Wilkinson et al. 2013). This test whilst being an essential part of the methodology (73\% of 2018-2019 publications) is, however, unable to detect small changes in tracer concentrations which can have significant effects on source apportionment estimates. Accordingly, bi-plots have been used as a more sensitive conservatism test (Oldfield and $\mathrm{Wu} 2000$ ) and are becoming increasingly used by recent international studies (39\% of 2018 2019 publications). Bi-plots are particularly sensitive to tracer non-conservatism when two tracers are correlated in the source groups, and it can be determined if the relationship between the two is maintained in the target sediments. Here, there is considerable overlap between particle size selection and tracer conservatism as if the particle size distribution of sources and sediments is significantly different; it would be expected that a significant number of tracers would fail a conservatism test. Whilst the fractionation of source samples into a range of particle size fractions can be combined with bi-plots to attempt to separate these effects, such methods are highly time and resource intensive (Pulley et al. 2015b). Although a single composite fingerprint which achieves strong discrimination can be adequate to estimate robust results, the use of multiple different composite fingerprints can give greater 
assurance that tracer non-conservatism or poor discrimination is not causing uncertainties in fingerprinting results and this approach is recommended. In the 2018-2019 studies reviewed here, however, the use of more than one composite fingerprint remains uncommon (27\% of publications).

Following the above critical steps for robust source discrimination, an un-mixing model is used for source apportionment. Here, it is of particular concern that $5 \%$ of the 2018 2019 publications reviewed lacked even a Monte Carlo uncertainty routine which has been increasingly seen as standard since introduced by Franks and Rowan (2000). The use of artificial (Haddadchi et al. 2014; Upadhayay et al. 2018a; Gaspar et al. 2019; Uber et al. 2019) or virtual (Palazón et al. 2015; Pulley and Collins 2018) sample mixtures for evaluating un-mixing model predictions is strongly recommended, regardless of tracer types. However, their use remains limited (29\% of 2018-2019 publications). Physical mixtures of source samples have some potential advantages, compared with virtual mixtures, since the former are designed to mimic the mixing of source-specific sediment. Real artificial mixtures do, nevertheless, require greater resources in terms of staff time and laboratory budgets. The mixing and splitting of source samples for combination into artificial mixtures can introduce errors. Virtual mixtures may be as simple as putting source group medians through the un-mixing model to represent a $100 \%$ contribution from each source or taking the mean of two sources to represent a $50 \%$ contribution from each. Where differences between the texture distributions of the source samples used to generate the source-specific tracer concentrations being mixed into virtual target sediment mixtures are pronounced, the use of such mixtures can encounter problems associated with bias. Equifinality can render an unmixing model mathematically unsound where there are multiple combinations of different source contributions which can produce the tracer concentrations measured in a target sediment sample. Mixtures are a key method for the assessment of this source of uncertainty. It is commonly considered that n-1 tracers for the number of source groups are required in a composite fingerprint. However, in practice, it is often not fully appreciated that each of the sources must be discriminated strongly by at least one tracer. This is especially of concern when multiple source groups ( $>3)$ are used as it is unlikely that sufficiently strong discriminators are available for all sources. Here, it is recommended that mixtures of a $100 \%$ contribution from each source are trialled as an absolute minimum to ensure that each source is recognized by the unmixing model before a study is considered suitably robust. Goodness-of-fit (GOF) has long been used to assess the reliability of modelling outputs. However, recent work (Gaspar et al. 2019) using synthetic sample mixtures has shown that GOF has little relation with model accuracy and therefore a high GOF cannot be accepted alone as robust evidence that model predictions are accurate. Instead, synthetic (actual or virtual) mixtures represent a more state-of-the-art and robust method of evaluating un-mixing model results.

A critical decision for fingerprinting studies concerns the sampling of target sediment, i.e. the sediment that is being apportioned and, which should be representative of the study catchment. Target sediment can include suspended, channel bed, floodplain and reservoir or lake sediment. Critically, the choice of the type of target sediment depends on the specific objectives of the study and, for this reason, this element has not been benchmarked. If understanding how sediment sources change through storm events or between events is of interest, then storm samples of suspended sediment should be collected (Mukundan et al. 2012; Gellis et al. 2015). Suspended sediment can be collected using several approaches: manual samples, automatic pump samplers and passive samplers (Phillips et al. 2000). Bed sediment reflects sediment that is eroded and deposited over several events and has been used to source sediment over time periods of weeks to months or years (Miller and Orbock-Miller 2007). Floodplain sediment, which has been used in sediment fingerprinting, is deposited during larger flow events that may occur at a frequency of years (Miller et al. 2015). If the objective is to obtain a target sample that is representative of long-term conditions in the order of years, lake or reservoir sediment may be more appropriate. Lake cores have been used for understanding sediment sources over historic and geologic time scales (Foster et al. 1998).

\section{Outstanding issues requiring further research and consensus}

The following sections review a number of essential topics related to sediment source fingerprinting that require further work and consensus. These topics emerged during the initial discussions between the authorship team over the detail of this new paper and reflect critical research or standardisation gaps.

\subsection{Spatial variability in tracers and sampling implications for end-members}

The spatial variability of tracers across scales (e.g. at an individual end-member sampling location or at larger scales across each end-member sampled within the catchment in question) and the scope to capture this with different sampling strategies commonly employed in sediment fingerprinting studies merit further investigation. To date, only a few studies have explored tracer spatial variability at an individual sampling location representative of a particular source endmember (e.g. Du and Walling 2017; Pulley and Collins 2018; Collins et al. 2019). The same is true for spatial variability over larger scales (Wilkinson et al. 2015). Accordingly, there remains a need to expand existing work to include more 
tracers and to confirm the sensitivity of source apportionment estimates to different sampling strategies. There is a rich history of use of spatial statistics in soil science (McBratney et al. 2003; Lark 2012; Minasny and McBratney 2016), where models for spatial exploration, prediction, classification, sample design/re-design and improved regression inference have all been constructed, and clearly, the sediment fingerprinting community should interact more with such expertise. In the case of the former, a field will often represent an individual sampling location for a given (e.g. land use category) endmember. Here, in an ideal world, the commonplace practice of bulking replicate samples from the same field into a single composite should be avoided, as it provides no assessment of microscale tracer variability, but resources do not support this idealism. Critically, it is not guaranteed that a bulked value is equivalent to the mean of separately analysed replicate samples, wherein a measure of variance is possible. Spatial configuration of the sampling is also important with a ' $\mathrm{W}$ ' (sampling along a W-shaped zig-zag path), transect or random sampling protocol, all being commonplace. The orientation of the $\mathrm{W}$ or transect should try to traverse all major sources of within-field variation, whilst also recognising any obvious connectivity pathways. If preferential (e.g. clearly visible erosion hotspots) sampling is undertaken, it should be consistent across all fields/locations of the target landscape and across all tracers, so resultant biases are interpretable (e.g. consistent over-prediction or under-prediction, but not mixtures of both), especially when it comes to implementing the un-mixing models for source apportionment. Where resources permit, a pilot sampling strategy can be used to inform subsequent sample re-designs to capture maximum tracer variability at a minimum cost. Re-designs can be further refined to cater optimally for any desired preferential sampling of areas (e.g. highly connected slope-to-channel pathways), times and depths of most interest for a given tracer or group thereof. Over a period of time, and provided far more studies followed similar twostage sampling protocols (pilot-to-optimally re-designed), it is likely that useful 'rules of thumb' would evolve for a range of spatial tracer designs and thus negate the need for many pilot studies. Here, the concept of 'external objectivity' (Matheron 2012) is noteworthy, where the value of a given statistically robust methodology can be assessed by its performance in the 'long run' through an increasing number and variety of applications.

\subsection{Temporal variability in tracers and sampling implications for end-members and target sediment}

Catchment sources can be dynamic environments, and, consequently, the potential for their fingerprints to vary temporally should be explored. Even if exposed to the same climatic conditions, end-member fingerprints are subject to biotic and abiotic factors that result in temporal changes (e.g. Lauber et al. 2013; Collins et al. 2019). Still, we have a limited understanding of the magnitude of those changes and their predictability and of how the temporal variability of end-member fingerprints compares with the spatial variability within and between end-members. Independently of the temporal scale of investigation, from individual storm runoff events to decadal timeframes (see Laceby et al. 2019), end-member sampling is often limited to a single sampling campaign. The main reason for this being that robust evaluation of temporal variability requires repeat sampling and thereby has resource implications which are often prohibitive in the context of research budgets.

Collins et al. (2019) investigated if $\delta^{13} \mathrm{C}, \delta^{15} \mathrm{~N}, \mathrm{TC}$ and TN could be used to discriminate top and sub-soil at field scale. The authors combined assessment of potential spatial and temporal variations in soil properties and found that all tracers exhibited some statistically significant temporal variation. Overall, the results suggested that temporal variation might also be relevant in sediment fingerprinting studies conducted at larger scales. Reiffarth et al. (2019) investigated the potential of compound-specific stable isotopes (CSSIs) to trace soils derived from different cultivated fields. The authors reported that variability in $\delta^{13} \mathrm{C} \mathrm{FA}$ values increased in fall and spring, which could affect the number of sub-samples required per source. They argue that more research is required to investigate intra- and interannual isotope tracer variation (i.e. tillage effects and seasonality). Special attention should also be made in study sites where large events are likely to occur during the period of investigation (e.g. typhoons; see Chartin et al. (2017) and Evrard et al. 2019a) or where anthropogenic disturbance might cause significant impacts over a short time period and result in more pronounced temporal variability in endmember signatures.

Sediment origin can exhibit significant variations both within and between storm runoff events (Carter et al. 2003; Nosrati et al. 2018), and high temporal resolution sediment tracing can provide useful information not only on phasing between flow and sediments during events but also on potential sources that affect different stages of the hydrograph (e.g. Vale and Dymond 2020). However, despite the need to obtain reliable and high-frequency information on target sediment fingerprints, studies are often hampered by difficulties in obtaining samples of sufficient quality and quantity for laboratory analyses and by analytical limitations and costs (Horowitz 2013; Conn et al. 2016). This, in turn, restricts high-frequency sampling campaigns to a limited number of events. During the last decade, progress in environmental monitoring has facilitated the collection of hydrochemical data at high frequency (e.g. minutes), including nutrient concentrations (i.e. $\mathrm{C}, \mathrm{N}, \mathrm{P}$ ), species (e.g. $\mathrm{NO}_{3}, \mathrm{NO}_{2}, \mathrm{NH}_{4}$ ) and 
composition (e.g. DOM); see Blaen et al. (2016) and Ruhala and Zarnetske (2017) for reviews. These newly gained datasets have significantly improved our mechanistic understanding of catchments (Rode et al. 2016), but we are still limited by the significant uncertainties in hydrological observations (Beven et al. 2020). In sediment source tracing, a next leap forward in environmental monitoring is to develop field deployable, robust and affordable sensors for measuring sediment fingerprints at high temporal resolution and over long periods of time (Horowitz et al. 2015). There are many advantages of using field deployable instruments to estimate suspended sediment composition in situ, including (i) shorter periods between monitoring and generation of results, (ii) elimination (or reduction) of sample preservation and transport issues experienced with conventional auto-sampling approaches, (iii) the possibility of acquiring fast and reliable data about pollutant levels in emergency situations, (iv) reduction of energy consumption (when compared with laboratory analyses) and (v) reduction of reagent use and waste (Galuszka et al. 2015 and references therein).

Recently, Martinez-Carreras et al. (2016) demonstrated that absorbance data measured with a spectrophotometer can be used to estimate suspended sediment properties reliably. The authors installed a spectrophotometer at the outlet of the Weierbach catchment (Luxembourg; $0.45 \mathrm{~km}^{2}$ ) and measured stream water light absorbance. They then measured percentage weight loss-on-ignition (LOI) on suspended sediment samples collected fortnightly during the monitoring period and during a storm runoff event to calibrate a regression model able to predict suspended sediment LOI from light absorbance. LopezRoldan et al. (2016) successfully predicted the contribution of the water origin to the Barcelona drinking water network using data from a spectrophotometric probe and a small number of physico-chemical parameters, whereas Noij and Bobeldijk (2003) used data from a spectrophotometric probe to detect the intrusion of chemical and microbiological constituents in a water network. Current investigations are addressing the potential use of high-frequency absorbance data for sediment source tracing (Lake et al. 2019), but many challenges are still to be addressed before absorbance can be routinely used for tracing, including assessment of tracer conservatism and influence of particle size distributions. Such sensors limit available tracers and thereby may not be suitable for fingerprinting sources in some catchments. Accordingly, the use of UV-VIS sensors should be seen as complementing, not replacing, traditional grab sampling campaigns (Sobczak and Raymond 2015). It will always be necessary to collect some samples periodically to calibrate a sensor, to provide cross-checks to detect unreliable instrument readings and to validate the raw spectra before use (Gamerith et al. 2011). Moreover, system stationarity should not be assumed and calibrations should be controlled regularly (Horowitz 2013).

\subsection{Tracer conservatism and knowledge-based pre- selection}

One of the key requirements in a successful sediment fingerprinting exercise concerns the selection of a combination of tracers for source apportionment (e.g.Walling et al. 1993; Gellis and Walling 2011; Walling and Foster 2016; Collins et al. 2017). Within this context, a tracer can be the concentration of an inorganic (e.g. $\mathrm{Al}, \mathrm{Ti}, \mathrm{Li}$, radioactive or stable isotopes, elemental ratios, mineralogy), or an organic (e.g. $n$ alkanes, fatty acids, pharmaceuticals, disinfection by-products) constituent or a physical measurement (e.g. particle size, density, magnetic susceptibility, colour). A useful tracer, regardless of type, has to meet two specific criteria: (1) it must be able to uniquely identify and differentiate between potential sources, and (2) it must be conservative (stable) during the transit time from its source point to where it was collected as part of a target (e.g. suspended, bed, lake core) sediment sample, downstream of all the potential sources in a catchment (e.g. Foster and Lees 2000; Collins et al. 2017).

In the context of sediment source fingerprinting, the term conservative means that the concentration/measurement will remain unchanged, at least within sampling/analytical/measurement error, as the mobilized material traverses and is routed through the system under evaluation. Tracer properties may change at different stages of sediment transfer trajectories from source to sink. Here, there is the potential for two possible scenarios: (1) tracers may transform before the mixing of material mobilized and delivered from the individual sources and/or (2) after mixing of the source-specific mobilized material into the target sediment. Whilst the potential sources of sediment within different catchments tend to be fairly similar, their relative contributions to the target sediment sampled tend to be system-specific. As such, the selection of an appropriate set of tracers for a particular system can represent an extensive and resource intensive watershed-specific trial-and-error exercise.

Although both criteria (differentiation and conservatism) are equally important for tracer selection, they are presented in the order in which they typically would be applied during a fingerprinting exercise. Further, more tracers are likely to meet the first criteria (differentiation) than to meet the second one (conservatism). Hence, conservatism (stability) is likely to be more limiting in tracer selection than discrimination between potential sources (e.g. Foster and Lees 2000; Collins et al. 2017). Conservatism results from the level of chemical/ geochemical/mineralogical stability associated with each potential tracer or group of tracers. In various aquatic environments, that stability is a function of a tracer's chemical reactivity in response to the range of physico-chemical and 
biological conditions extant. On that basis, among the categories of potential tracers, stability is likely to rank, from higher to lower as follows: physical measurements $>$ inorganic constituents $>$ organic constituents. Hence, all things being equal, the utility of potential tracers probably should be evaluated in that order. This general rule-of-thumb should apply in catchments characterized by typical potential sources such as geological units, managed forests, cultivated hillslopes, intensively managed pastures, channel banks, road cuttings/surfaces/ verges and instream (secondary) sources. Alternatively, in catchments containing atypical sources such as specific extraction operations (e.g. coal, gold, base metal mining), urban areas or a particular manufacturing/processing facility (e.g. pharmaceuticals, galvanizing plant, smelter, petrochemicals, sewage treatment), appropriate tracers may be self-evident, regardless if the tracer is a physical measurement or a chemical constituent (e.g. Horowitz and Stephens 2008).

Assessment of tracer conservatism is both a critical element of state-of-the-art procedures and an outstanding issue, since it is accepted and widely reported that current standard tests remain a black-box approach (Koiter et al. 2013a). Limited work (e.g. Motha et al. 2002) to date has investigated tracer conservatism explicitly, and case studies continue to apply conventional tests. Regardless of the test used for tracer conservatism, when the target sediment samples do not pass these tests, there are two possibilities: (1) missing sources and/or (2) enrichment/depletion of tracer values due to various processes including, for example, hydrodynamic sorting or biomarker degradation/addition. In other words, that particular tracer or set of tracers is behaving non-conservatively. The international sediment fingerprinting community is aware of the impact of non-conservative tracers on the uncertainties associated with estimated source contributions (Cooper and Krueger 2017); however, there is no formal agreed test to detect tracer transformation during sediment generation, delivery, postdeposition and collection. On this basis, expert opinion is inevitably crucial and one of the key aspects of selecting the most suitable and reliable tracers for sediment source apportionment.

\subsubsection{Inorganic tracers}

End-users of sediment fingerprinting should be aware that different analytical procedures are likely to produce different concentrations for specific sediment-associated constituents (tracers); this is particularly true for matrix-bound inorganic elements because total ( $\geq 95 \%$ recovery of what is present) quantitation typically depends on completely solubilizing the sediment particles prior to analysis (e.g. Horowitz 1991, 2013). Whilst this analytical approach ensures complete quantitation of matrix bound constituents, that should not be taken to mean that this value actually will be the most useful in differentiating between potential sources within a catchment.
In some cases, specific partial extractions prior to chemical analysis (e.g. Chao 1984; Horowitz 1991; Hall and Pelchat 1999) might produce more useful values for differentiating sources. Final decisions, like tracer selection, regarding methods of quantitation may turn into a trial-and-error exercise for each study area.

Among potential inorganic tracers, conservatism is a function of reactivity (chemical stability) that, in turn, is a function of the chemistry of the tracer itself (e.g. transition metals, rare earth elements, radionuclides, stable isotopes), as well as how it is bound to the sediment. As such, the most conservative inorganic tracers are likely to be matrix-bound elements that include such constituents as $\mathrm{Si}, \mathrm{Al}, \mathrm{Ti}, \mathrm{Zr}$ and the rare earth elements (e.g. Y, Yb, Gd, Sm). In terms of chemical stability, individual minerals (e.g. crystalline oxides such as rutile $\left(\mathrm{TiO}_{2}\right)$ or sulphides such as pyrite $\left.\left(\mathrm{FeS}_{2}\right)\right)$ probably are on a par with matrix-bound elements because they usually are unaffected by the $\mathrm{Eh} / \mathrm{pH}$ ranges found in most catchments. On the other hand, carbonate minerals (e.g. calcite/aragonite $\left(\mathrm{CaCO}_{3}\right)$, dolomite $\left(\mathrm{CaMg}\left(\mathrm{CO}_{3}\right)_{2}\right)$ that can be affected by changes within the normal $\mathrm{pH}$ range of some catchments would not be as stable. Typical trace elements, such as $\mathrm{Pb}$, $\mathrm{Zn}, \mathrm{Cd}, \mathrm{Cu}$ and $\mathrm{Ag}$, that are associated with sediment surfaces via sorption onto Fe oxide coatings, or organic carbon films, are likely to be more chemically reactive, and hence less conservative, than matrix bound constituents or individual minerals. The relative levels of chemical reactivity of a number of inorganic constituents that could serve as tracers (Fig. 4) often is related to their solubility (Meybeck and Helmer 1989). As such, the order of preference should range from lower to higher solubility (from the bottom right to the top left; Fig. 4). Whilst low solubility is a strong indicator of tracer conservatism, how the constituent is bound to a sediment particle also exercises a substantial amount of control. As an example, both $\mathrm{Zn}$ and Al have roughly the same solubility (Fig. 4); however, the former normally is sorbed to the surfaces of sediment grains whereas the latter normally is matrix bound. As a result, $\mathrm{Zn}$ concentrations are more likely to change as the sediment particle traverses a catchment as a result of sorption/ desorption processes, whereas $\mathrm{Al}$ cannot. Hence, despite similar solubilities, $\mathrm{Al}$ is likely to be more conservative than $\mathrm{Zn}$.

\subsubsection{Biomarkers/organic tracers}

Degradation of biomarkers (e.g. fatty acids, alkanes) over multiple scales during sediment generation and transport in a catchment can be responsible for non-conservative behaviour. Specifically, microbial mineralisation and re-synthesis transform the isotopic composition of biomarkers (Matsumoto et al. 2007). However, degradation-induced kinetic isotope fractionation can be independent of sources, carbon-chain length, grain size and sampling season. Given that sediment tracers are mainly associated with fine-grained minerals, 


\section{Ratio Between Natural Dissolved and Total Elemental} River Transport ${ }^{1}$ (from Meybeck and Helmer, 1989)

\section{$\begin{array}{llll}99 \% & 90 \% & 50 \% & 10 \%\end{array}$ \\ Cl|Br S $\mid \mathrm{Na}$ Sr C Ca Li $\mid \mathrm{Sb}$ Mg N B Mo As F Ba K $|\mathrm{Cu} P| \mathrm{Ni}$ Si Rb U Co Cd}

\section{Mn Th V Cs $\mid$ Ga Pb Lu|Ti Gd La Ho Yb Tb Er Sm Cr Fe Eu Ce Zn Al|Sc Hg \\ $1 \% \quad 0.5 \%$ \\ $0.1 \% 0.05 \%$}

Fig. 4 The relative solubility (hydrophobicity) of selected inorganic constituents in natural waters. The lower the solubility, the greater the stability. Stability increases from the lower right to the upper left of the figure (after Meybeck and Helmer 1989)

hydrodynamic sorting processes can exert a significant influence on both the content and isotopic signature of biomarkers (Fig. 5) in river sediment (Laceby et al. 2017). Moreover, the biomarkers associated with larger grain-size fractions often associated with plant debris are typically younger compared with the finer fraction (Yu et al. 2019). Biomarkers in the finer fractions especially short-chain ( $<20 \mathrm{C}$ atom) are likely to be non-conservative due to their mineralisation and re-synthesis.

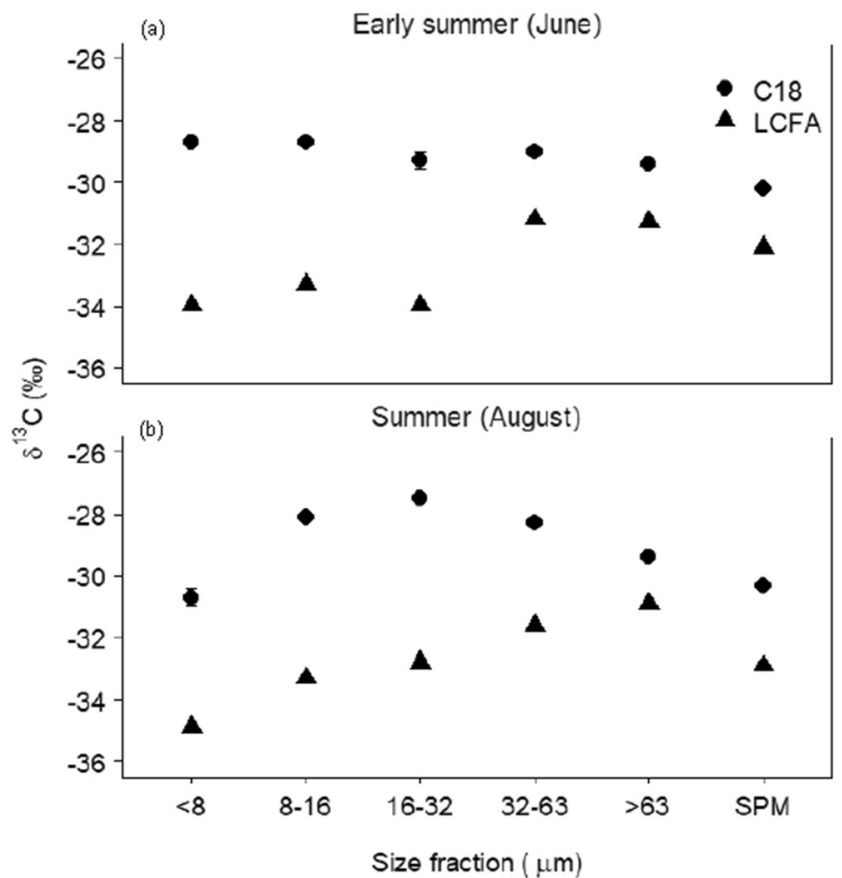

Fig. 5 Carbon isotopic $\left({ }^{13} \mathrm{C}\right)$ values of FAs (fatty acids) among size fractions in a early summer and $\mathbf{b}$ summer suspended particulate matter from the Yellow River, China. LCFA indicates the abundance-weighted average values of the $\delta^{13} \mathrm{C}_{26+28+30}$ FAs (after Yu et al. 2019)
Therefore, the conservative behaviour of the isotopic composition of biomarkers should be assessed carefully.

Plant-based biomarkers are promising for identifying land use-based sediment sources and their relative contributions to target sediment samples. These biomarkers are incorporated into the soil by higher plants from rhizodeposition and decomposition of organic matter and thus inherit the ${ }^{13} \mathrm{C}$ signature of the vegetation from which they emanate (Reiffarth et al. 2016; Upadhayay et al. 2017). Because of their lower aqueous solubility, these biomarkers tend to be more resistant to microbial degradation than short-chain homologues in soil and sediment environments. Preservation is typically higher for alkanes relative to fatty acids (Cranwell 1981) and the latter are less likely to be adsorbed on soil particles due to lack of a functional group. It is important to acknowledge, however, that alkanes provide a means of understanding organic carbon origin rather than the source of soil mineral particles. Nevertheless, long-chain ( $>20 \mathrm{C}$ atom) $n$-alkanes and $n$-fatty acid stable isotope composition do provide insights into the origin of soil organic carbon from different land uses since these biomarkers are almost exclusively produced by higher plants (Dinel et al. 1990; Eglinton and Eglinton 2008; Upadhayay et al. 2020a).

It is still necessary to assess carefully the content of biomarkers to confirm conservative behaviour. This is important, since biomarker degradation and/or addition and associated isotopic transformation within catchment systems are highly complex, and the standard mathematical approaches used in sediment sourcing studies for tracer conservatism fail to detect such transformation. For illustrative purposes, Fig. 6 shows that the $\delta^{13} \mathrm{C}$ values of the $\mathrm{C} 18: 0$ and $\mathrm{C} 32: 0$ fatty acids in target sediment samples are within the corresponding ranges of the potential sediment sources, but the sediment C18:0 


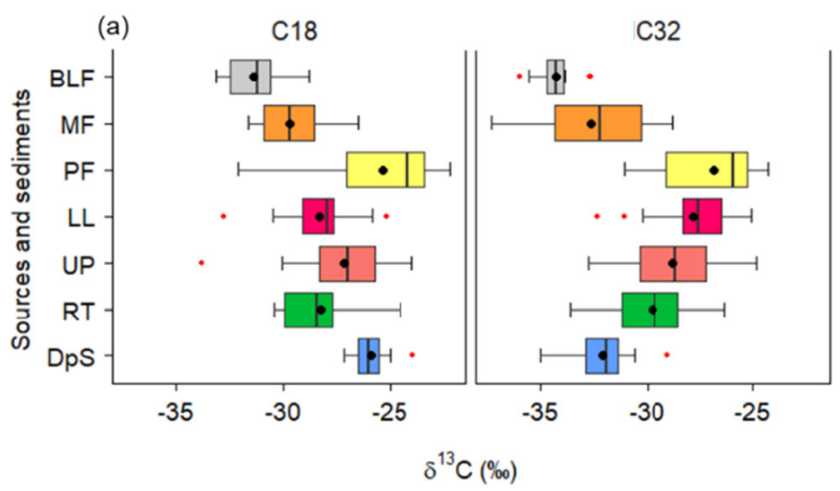

(b)

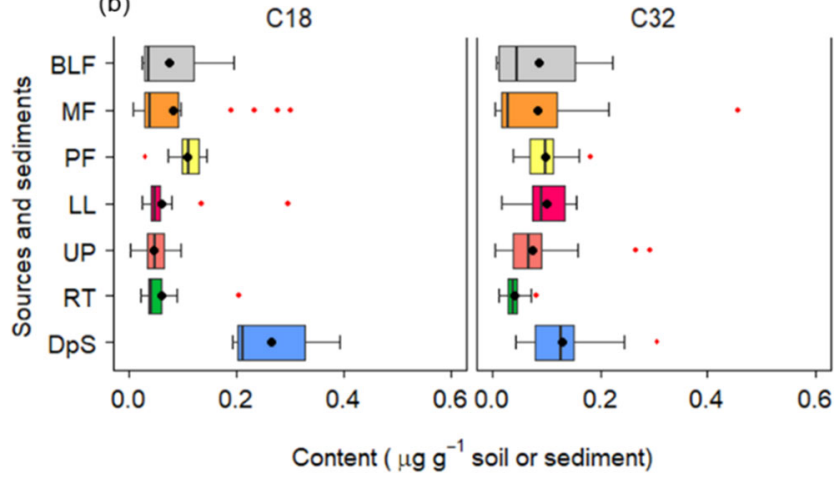

Fig. 6 Distribution of $\delta^{13} \mathrm{C}$ values (a) and content (b) of representative short-chain (C18) and long-chain (C32) saturated FAs (fatty acids) in potential sediment sources (BLF, broadleaf forest; MF, mixed forest; PF, pine forest; LL, lowland agricultural terraces; UP, upland agriculture terraces; RT, road tracks) and target sediment (Dps) in the Chitlang stream, Nepal (after Upadhayay et al. 2018b)

content is highly enriched compared with the sources (Fig. 6). This example clearly illustrates that the $\delta^{13} \mathrm{C}$ values of $\mathrm{C} 18: 00$ in the land uses are obscured by other sources (e.g. algae) since short-chain fatty acids are also produced by microorganisms and aquatic plants. Additionally, the presence of bacteria can cause long-chain fatty acids to undergo degradation and to resynthesize as short-chain fatty acids (Fang et al. 2014). It should also be noted that fatty acid content can also be higher in target sediment samples compared with source materials due to fining of grain size in conjunction with hydrodynamic sorting processes and selective delivery. Nevertheless, investigators are advised to use long-chain saturated fatty acids for sediment source fingerprinting (Alewell et al. 2016; Upadhayay et al. 2017) and to take explicit account of sediment sorting (Yu et al. 2019).

\subsubsection{Sedimentary deposits}

The shortcomings associated with current conservatism tests are also relevant to fingerprinting studies using sedimentary deposits as target sediment. Many factors will affect the preservation of physical, inorganic and organic signatures of material deposited at the bottom of lakes and reservoirs potentially leading to alteration of the signatures and failure of the fingerprinting method. The bottom sediments themselves may be derived from at least four different sources: (1) from the atmosphere and (2) the catchment via rivers (both allogeneic sources), (3) from the lake itself through processes like bank erosion and organic matter production (authigenic) and/or (4) produced internally by organisms living within the upper few centimetres of the lake sediment (allogeneic). In the latter case, physical mixing of sediment and oxidation is likely to occur whereas sediment deposited below the biologically active layer is likely to be strongly reducing (e.g. Svensson et al. 2001; Baranov et al. 2016). In situ production of minerals (e.g. bacterial magnetite and greigite) and dissolution of minerals under strongly reducing conditions can confound the use of magnetic mineralogy for fingerprinting lake sediments (Foster et al. 1998, 2008; Sandgren and Snowball, 2001). Whilst many of the physical properties like particle size may not change through post depositional diagenesis, other chemical and/or organic properties may be significantly affected by dissolution and vertical diffusion. Dissolution and vertical diffusion appear to be Eh dependent, and the strength of reducing conditions determines which elements are likely to be more mobile (Fig. 4). In some cases, evidence for remobilisation has come from the use of ratios of potentially more mobile elements (e.g. $\mathrm{Mn}, \mathrm{Fe}$ ) to more stable elements (e.g. Al, Ti) (Reynolds et al. 2004).

\subsection{The physico-chemical basis for source discrimination}

Despite significant developments in the variety of properties available along with almost exponential advances in unmixing model capabilities, advances in our understanding of the physico-biogeochemical basis for source discrimination have arguably not kept pace. This, in part, reflects failure of the user community to engage with appropriate expertise. As more laboratories are equipped with relatively affordable instrumentation that can now generate a variety of fingerprint properties, it would be beneficial to focus some research attention on whether the hypothesized physico-biogeochemical foundation behind source discrimination is maintained during sediment generation, transportation and deposition processes and whether or not we need to consider moving beyond the current conservation tests and other statistical approaches and include more of the physico-biogeochemical science. Confirmation of the physico-chemical basis for source discrimination therefore remains an important knowledge gap for the selection of some fingerprint properties in composite signatures.

The historical development of the approach has been generally based upon the hypothesized discrimination provided by physical and biogeochemical parameters between one and more potential sediment sources. For example, the application of ${ }^{137} \mathrm{Cs}$ and ${ }^{210} \mathrm{~Pb}_{\mathrm{ex}}$ as effective fingerprinting properties was 
built upon the understanding that these fallout radionuclides have greater concentrations in surface soils relative to subsurface soils, with cultivated soils exhibiting properties typically in between these two distinct end-members (Walling and Woodward 1992; Olley et al. 1993; Wallbrink et al. 1999). The utility of total organic carbon and total nitrogen concentrations is built upon a similar understanding in that these organic parameters typically decrease with soil depth (Walling et al. 1993; Mariotti and Peterschmitt 1994; Walling and Woodward 1995). Elemental geochemistry, colour and mineral magnetic parameters theoretically have tracers in their analysis suites that provide significant discrimination between potential soil types, dominant rock types or land uses (Walling et al. 1979; Hutchinson 1995; Collins et al. 1997; Poulenard et al. 2009). More recently, compoundspecific stable isotopes have been selected based upon discrimination provided by the labelling of soils by degrading organic matter (Gibbs 2008; Reiffarth et al. 2016). For the majority of the properties utilized in the sediment source fingerprinting literature, there is, therefore, a known or hypothesized physical and/or biogeochemical basis for source discrimination that justifies their direct incorporation into unmixing models (Fox and Papanicolaou 2007; Hatfield and Maher 2008; Olley et al. 2013; Cooper et al. 2015; Le Gall et al. 2017b).

Another approach to select fingerprinting properties is the utilisation of statistical procedures. In particular, the standard three-step approach to selecting fingerprinting parameters for use in end-member modelling includes some variant of a bracket test to remove non-conservative parameters followed by statistical tests (e.g. Kruskal Wallis H-test, DFA) to select an optimal group of fingerprints for modelling (Collins et al. 1996). The foundation of the statistical approach is based on incorporating a wide variety of fingerprinting parameters that should theoretically provide discrimination between the potential sources (Walling et al. 1993; Collins et al. 1996, 1998; Collins and Walling 2002). Collectively, the entire suite of fingerprinting parameters analysed is assumed to provide some physico-biogeochemical source discrimination and it is rightly argued that including more fingerprint properties in this three-step statistical procedure, should in theory, provide more accurate and consistent source apportionment results (Collins and Walling 2004; Walling 2005).

However, at times, it may be difficult to justify the physicobiogeochemical basis supporting the final selection of tracer properties obtained in each step of the widely used statistical procedure. This challenge is exemplified by the large number of potential tracing parameters often measured in routine analyses (e.g. ICP-MS, colour, mineral magnetics properties, radionuclides). For example, regarding the conservative behaviour of fingerprint properties, Smith and Blake (2014) excluded phosphorus $(\mathrm{P})$ from the potential set of tracers on the basis of the risk of non-conservative behaviour during downstream transport. Kraushaar et al. (2015) combined additional physiochemical information on the sedimentation environment through water sample analyses, correlation analyses and a literature review to exclude multiple properties that may exhibit non-conservative behaviour from modelling (i.e. $\mathrm{Na}, \mathrm{Ca}$, $\mathrm{K}, \mathrm{Mg}, \mathrm{Sr},{ }^{40} \mathrm{~K}$ and TOC).

Koiter et al. (2013a, b) incorporated geological knowledge of their catchment rather than statistical tests to select properties. Laceby et al. (2015) and Batista et al. (2019) further demonstrated the utility of these knowledge-based approaches to trace, respectively, sediment derived from different geologies and soil types. Smith and Blake (2014) justified the selection of several geochemical properties to discriminate between surface and sub-surface sources on the basis of differences resulting from the weathering gradient varying with soil depth and soil surface contamination. Indeed, there has been a recent emphasis to justify the parameters selected by the three-step statistical procedure (e.g. Mukundan et al. 2010; Vale et al. 2016; Sellier et al. 2020) and investigators are encouraged to adopt this level of scrutiny, rather than relying on statistical solutions alone (Collins et al. 2017).

\subsection{Dissemination of sediment source fingerprinting results to key landscape actors}

Despite the ongoing growth in publications utilising the sediment source fingerprinting approach, research into how landscape actors, implicated as a potential driver of excess sediment loadings, engage with the fingerprinting results is still lacking. As agricultural land is often a dominant source supplying excessive sediment loads to river systems around the world, fingerprinting data needs to be delivered directly to farmers and landowners alongside policymakers. However, farmers, catchment officers and policymakers may all have varied information requirements. Whilst many non-scientists may prefer simplistic summaries of scientific procedures and the findings, others may demand a detailed overview and qualification of the robustness associated with the employed research methodologies. Scientists may, however, struggle to communicate with farmers due to their different epistemologies, approaches, values, attitudes and experiential knowledge (Raedeke and Rikoon 1997; Tsouvalis et al. 2000; Eshuis and Stuiver 2005). Collaboration with trusted farm advisors may offer an effective delivery mechanism for disseminating results, as local one-to-one advice delivery is a highly effective mechanism for engaging with farmers and other landscape actors (Dwyer et al. 2007). When engaging with policymakers, the delivery of findings should occur during policy windows (Rose et al. 2017). Where source fingerprinting data contradict personal experiences or depict a lack of practical understanding, it is unlikely that they will be perceived as trusted or relevant by non-scientists (Eshuis and Stuiver 2005). Collaborative research with social scientists is 
warranted to determine whether a greater uptake of interventions for reducing excess sediment loadings may result from presenting the findings of source fingerprinting studies to local actors and policymakers.

\section{Emerging themes in sediment fingerprinting research and applications}

\subsection{Novel tracers}

Although suites of conventional properties (e.g. elemental geochemistry, radionuclides, mineral magnetics) have been used effectively to differentiate between major land use sources (e.g. cropland, forests, grassland) supplying sediment to receptors (Huon et al. 2013; Laceby et al. 2016; Lizaga et al. 2019), there is a fundamental need to increase the resolution of land use and land cover source discrimination. To achieve this goal, researchers have developed approaches to trace sediment sources based upon source soil and sediment compoundspecific stable isotope (CSSIs) signatures (Gibbs 2008). To date, the CSSI approach has been limited to the use of fatty acids and alkane carbon isotopic composition to identify the contribution of fields under specific crop rotations (Blake et al. 2012; Mabit et al. 2018a, b), as well as sediment sources in forest plantations of Chile (Bravo-Linares et al. 2018) or mixed land use catchments (Upadhayay et al. 2018b). Integration of the $\delta^{2} \mathrm{H}$ values of long-chain alkanes and fatty acids in tracer sets has shown great potential for extracting additional information on sediment origin related to dominant vegetation types (Gao et al. 2011) and elevation gradients (Feakins et al. 2018). In addition, the isotopic composition and content of lignin-derived phenols and resin acids, as well as emergent biomarkers such as branched glycerol dialkyl glycerol tetraethers (brGDGTs) and methoxy-serratenes, have potential to distinguish the contributions of sediment from different land uses at catchment scale. Nonetheless, the development of this type of novel tracer technology faces several challenges including the inherent spatial and temporal variability of biochemical tracers (Reiffarth et al. 2016), the need to collect a large number of source samples and the potential importance of conducting multiple sampling campaigns to generate representative biomarker fingerprint properties of cultivated sources (Reiffarth et al. 2019).

To further increase the resolution of land cover tracing, another novel approach has been the potential use of $n$-alkanes, which are found in epicuticular waxes of leaves and are characterized by a slow degradation. These were first proposed for palaeoclimatic reconstructions (Eglinton and Eglinton 2008). More recently, this method was tested in a catchment in Southern Brazil to discriminate the sediment contributions supplied by Pinus taeda commercial plantations and those from native forests (Galoski et al. 2019). Biomarker analyses are expensive relative to many more conventional tracers and there remains a need to explore and confirm the incremental cost-benefits of their application in conjunction with traditional tracer types across a range of environmental settings with differing levels of source complexity.

With the rapid development of DNA sequencing technologies and the decrease in associated costs (Seymour 2019), environmental DNA offers another technique that may provide very detailed information on the vegetation types supplying sediment to river systems, with identifications that may go up to the species level (Evrard et al. 2019b). However, there remain several methodological challenges that require further research. In particular, upper organic and mineral topsoil layers were shown to be enriched in plant DNA compared with deeper soil horizons, which may complicate the use of this technique in catchments dominated by sub-soil erosion (Giguet-Covex et al. 2019).

Novel methods have also recently been proposed to refine the use of elemental geochemistry. For instance, the use of specific fractions of elements, generally obtained by sequential chemical fractionation using different extractors, has been promising for discriminating sediment sources, providing an excellent low-cost alternative to biomarkers or sediment DNA. For example, several P-fractions more sensitive to land use change have the potential to discriminate between sediment sources, especially in rural catchments where $\mathrm{P}$ is added via fertilizers (Tiecher et al. 2019). These authors demonstrated in a Brazilian rural catchment that whilst some operationally defined fractions of $\mathrm{P}$ in sediment sources are not conservative, some fractions (e.g. resin $\mathrm{P}, 0.5 \mathrm{M} \mathrm{NaHCO}_{3}-\mathrm{P}, 0.1 \mathrm{M}$ $\mathrm{NaOH}-\mathrm{P}$ and, total organic $\mathrm{P}$ ) can be used in combination with geochemical tracers to improve source discrimination compared with using geochemical tracers alone. Whether this improved discrimination can be extended to more complex catchments with greater numbers of $\mathrm{P}$ sources remains to be tested. One approach that may help is to study the different forms of organic $\mathrm{P}$ in sediments, especially the inositol phosphates which are typically the most abundant forms of organic $P$ in soils (Gerke 2015), via the use of $\mathrm{NaOH}$-EDTA extraction and P-31 NMR (Turner et al. 2003; Cade-Menun and Liu 2014). Recent advances in identifying previously unconsidered high-molecular weight complex organic $\mathrm{P}$ compounds in NaOH-EDTA extracts (Mclaren et al. 2019) offer further potential to develop organic $\mathrm{P}$ approaches for improving sediment source tracing.

The use of the stable oxygen isotope ratio $\left({ }^{18} \mathrm{O}\right)$ of phosphate $\left(\delta^{18} \mathrm{O}_{\mathrm{p}}\right)$ for tracing sources of phosphate has recently received increased attention. It works on the principle that the $\mathrm{P}-\mathrm{O}$ bond in phosphate is stable under typical environmental temperature and $\mathrm{pH}$ and is broken only by enzyme mediated reactions, thus meaning that the isotopic source values remain the same unless biological activity results in exchange between oxygen in water and oxygen in phosphate. 
This enzyme mediated exchange between water ${ }^{18} \mathrm{O}$ and phosphate ${ }^{18} \mathrm{O}$ is generally assumed to primarily be driven by pyrophosphatase which leads to an 'equilibrium' $\delta^{18} \mathrm{O}_{\mathrm{p}}$ value which can be predicted by water temperature and water ${ }^{18} \mathrm{O}$ (Chang and Blake 2015) but which leads to the original source $\delta^{18} \mathrm{O}_{\mathrm{p}}$ value being lost.

This methodology has been used successfully to trace the sources of wind-borne sediment (Gross et al. 2013, 2015, 2016). The application of this technique to trace sediment within the aquatic environment is, however, more complex (Pistocchi et al. 2017). The potential for multiple contributing sources, the overlap between different source $\delta^{18} \mathrm{O}_{\mathrm{p}}$ ranges and the equilibrium range, within the water column, the risk of dissolved phosphate from non-sediment sources becoming adsorbed and the cycling of sediment $\mathrm{P}$ and exchange with water ${ }^{18} \mathrm{O}$, can all challenge the approach. Granger et al. (2017) found that within a moderately complex catchment, sediment source $\delta^{18} \mathrm{O}_{\mathrm{p}}$ were similar to equilibrium values, meaning the source apportionment would have been impossible. Therefore, this method has limitations, but it may be effective in simple catchments with low sediment residence times and limited sources (Pistocchi et al. 2017).

Novel tracers have also recently been incorporated into sediment source fingerprinting through adopting approaches from other disciplines. For example, Nosrati et al. (2019) recently combined weathering indices (e.g. the chemical index of alteration, the weathering index of Parker, and the indicator of recycling) with geochemical tracers to investigate the spatial sources of suspended sediment in northern Tehran, Iran. Indeed, there is significant potential to develop novel tracers from other approaches utilized in Earth System sciences, including clay mineralogy, strontium $\left({ }^{87} \mathrm{Sr} /{ }^{86} \mathrm{Sr}\right)$ and neodymium $\left({ }^{144} \mathrm{Nd} /{ }^{143} \mathrm{Nd}\right)$ isotopes and rare earth element ratios (e.g. $\mathrm{Nd} / \mathrm{Yb}, \mathrm{Gd} / \mathrm{Yb}, \mathrm{La} / \mathrm{Sm}$ ) amongst others (Gingele and De Deckker 2005; Gholami et al. 2017a; Le Gall et al. 2017b). Some previous work has also illustrated the combined use of conventional sediment source fingerprints with artificial dualsignature (i.e. fluorescent and magnetic) tracer technologies to increase the spatial resolution of sediment (Collins et al. 2013) source information in both grassland (Collins et al. 2010) and arable (Collins et al. 2013) settings in the UK, and such approaches seem worthy of further testing, albeit in the context of the high costs of the dual-signature tracers which must be matched to the typical absolute grain size characteristics of the target sources and the high costs of the high strength magnets required for tracer sampling in the sediment receptor.

Although the development of novel tracers may increase our source discrimination capabilities, the importance of using multitracer (and multi-model) approaches was recently demonstrated as a means of averaging out the potential biases (e.g. source variability, particle size selectivity) associated with the different types of tracers (Uber et al. 2019). Accordingly, the integrated use of low-cost and high-resolution techniques should facilitate the analysis of a large number of samples to obtain reliable information on the variations in sediment source contributions (Evrard et al. 2019a). Spectroscopy, based on visible-nearinfrared and shortwave-infrared, provides more than 70 physically based spectral features that have potential to trace sediment and sediment-associated organic matter sources (Collins et al. 2013; Brosinsky et al. 2014).

The potential of portable equipment including XRF devices to directly measure potential tracing properties in the field also opens novel avenues for research (Turner and Taylor 2018). Here, the work proposed the use of $\mathrm{Rb}$ measurements to correct the metal concentrations estimated in the field on fresh sediment in which the presence of interstitial water diluted the sediment mass and attenuated the incident X-rays. The full potential of other low-cost and high-resolution techniques including hyperspectral spectroscopy imaging remains to be explored (Butz et al. 2015; Aymerich et al. 2016; Jacq et al. 2019).

\subsection{Inclusion of concentration dependence for biomarkers in sediment un-mixing models}

In the case of using isotopic abundance as a tracer (e.g. carbon, nitrogen), a significant source of uncertainty for source contributions is linked to not using biomarker content (i.e. biomarkers through which isotopic composition is derived) in un-mixing model formulation. Recently, land cover-dependent differences in the $\delta^{13} \mathrm{C}$ isotopic values of specific organic compounds (i.e. soil fatty acids, $n$-alkenes) have been used to estimate source contributions from different land use types without accounting for the effect of isotopic content on un-mixing model results (Gibbs 2008; Blake et al. 2012; Hancock and Revill 2013; Alewell et al. 2016; Brandt et al. 2016, 2018; Bravo-Linares et al. 2018; Mabit et al. 2018a, b). Here, the concentrationindependent approach assumes an identical isotopic tracer content for all sources. This, however, has recently been shown to be the exception rather than the rule (Upadhayay et al. 2018a). In contrast, the alternative concentration-dependent approach accounts for the non-linearity of isotopic mixing in sediment by correcting for the content dependency within the un-mixing modelling. Different relative tracer contents in potential sources have a significant impact on the shape of the un-mixing modelling polygon (Hopkins and Ferguson 2012). Therefore, Upadhayay et al. (2018a) strongly recommended the use of concentration-dependency in isotope mixing regardless of the model framework, i.e. Bayesian or frequentist.

\subsection{The age and residence time of fine-grained sediment}

Because sediment fingerprinting apportions the sources of delivered sediment, it cannot determine the residence time of the source sediment. Accordingly, we do not know if a portion of the target sediment travelled quickly from sources to the 
sampling point or whether it resided in storage zones for various time periods. As sediment travels from its origin to any sampling point, it can be deposited in storage on upland surfaces (i.e. colluvial slopes) (Smith et al. 2014) or in channel storage (i.e. the active channel bed, bars, and on floodplains) (Fryirs and Brierley 2001) for periods ranging from days or weeks to millennia (Lancaster and Casebeer 2007; Pizzuto et al. 2014; Hoffmann 2015). The time sediment remains in various storage units represent the residence time, whereas the sediment transit time is determined by the start and end points of where sediment enters and leaves the channel system.

It is difficult to know precisely the sites of sediment storage and transit times as sediment travels from source to sink. Therefore, investigations have examined the 'age' of sediment to infer its transit time from source to sink. To estimate sediment transit and residence times for sediment 'age', fallout radionuclides provide a marker for surface sediment (top soil) and provide useful chronometers, ${ }^{210} \mathrm{~Pb}_{\mathrm{ex}}$, which can date sediment to $\sim 85$ years and ${ }^{7} \mathrm{Be}$ to $\sim 1$ year (Mabit et al. 2008). Different methods have been developed to calculate sediment age, transit and residence times (Bonniwell et al. 1999). Matisoff et al. (2005) proposed a ${ }^{7} \mathrm{Be}^{210} \mathrm{~Pb}_{\mathrm{xs}}$ 'chronometer' to determine the age of sediment ( $t$; Eq. 1$)$ and the percentage of 'new' suspended sediment in the river (Eq. 2):

$$
t=\frac{-1}{\left(\lambda_{7 \mathrm{Be}-\lambda_{210 \mathrm{~Pb}}}\right)} \ln \left(\frac{A}{B}\right)+\frac{1}{\left(\lambda_{7 \mathrm{Be}-\lambda_{210 \mathrm{~Pb}}}\right)} \ln \left(\frac{A_{0}}{B_{0}}\right)
$$

where $\lambda_{7 \mathrm{Be}}$ and $\lambda_{210 \mathrm{~Pb}}$ are the decay constants of ${ }^{7} \mathrm{Be}$ and ${ }^{210} \mathrm{~Pb}\left(\mathrm{~d}^{-1}\right), A$ and $B$ are the ${ }^{7} \mathrm{Be}$ and ${ }^{210} \mathrm{~Pb}_{\mathrm{ex}}$ activities in suspended sediment samples $\left(\mathrm{Bq} \mathrm{kg}^{-1}\right)$ and $A_{0}$ and $B_{0}$ are the ${ }^{7} \mathrm{Be}$ and ${ }^{210} \mathrm{~Pb}_{\mathrm{xs}}$ activities in rainfall $\left(\mathrm{Bq} \mathrm{L}{ }^{-1}\right)$.

\%of'new'sediment $=100 \times \frac{(A / B)}{\left(A_{0} / B_{0}\right)}$

A decrease in the ${ }^{7} \mathrm{Be} /{ }^{210} \mathrm{~Pb}_{\mathrm{ex}}$ ratio can alternatively be explained by (i) an increase in the sediment residence time (given ${ }^{7} \mathrm{Be}$ decay is faster than that of ${ }^{210} \mathrm{~Pb}_{\mathrm{ex}}$ ) or by (ii) the dilution of sediment enriched in ${ }^{7} \mathrm{Be}$ by sediment depleted in ${ }^{7} \mathrm{Be}$. Using the ratios of ${ }^{7} \mathrm{Be}:{ }^{210} \mathrm{~Pb}_{\mathrm{ex}}$, Matisoff et al. (2005) determined ages of suspended sediment ranging between 0 and $\sim 300$ days.

Dominik et al. (1987) using ${ }^{7} \mathrm{Be},{ }^{210} \mathrm{~Pb}$ ex and ${ }^{137} \mathrm{Cs}$ suggested a 2-box age model for the alpine Rhône River, where topsoil particles travel slowly (800 to 1400 years) and a rapid box where high erosion moves particles between 1 and 220 days. Evrard et al. (2010) examined sediment residence time in a tropical watershed in central Mexico using ${ }^{7} \mathrm{Be}$, ${ }^{210} \mathrm{~Pb}_{\text {ex }}$ and ${ }^{137} \mathrm{Cs}$. Residence times were analysed with respect to a 2-box model similar to that of Dominik et al. (1987): a geologic box where soil is transported to the watershed outlet at time scales of 5000 to 23,000 years and a rapid box, where once in the channel, sediment travels over 50 to
200 days. Flood type, seasonality and land use all influence the timing and export of sediment (Evrard et al. 2010). The two-box model calculation (Dominik et al. 1987; Clarke 2008) requires the measurement of the fallout radionuclide input in a catchment and the corresponding radionuclide river output. The catchment surface is then subdivided into two boxes: (i) a 'soil-box' comprising the uppermost soil surface exposed to radionuclide fallout and (ii) a 'river-box' comprising the river and the nearby areas characterized by quicker transfers and shorter radionuclide residence times. The mean residence times of particles exposed to radionuclide fallout are calculated for each box. In the original work, Dominik et al. (1987) were confronted by the impossibility of totally solving the equations when using ${ }^{7} \mathrm{Be}$ and ${ }^{210} \mathrm{~Pb}_{\mathrm{xs}}$ and this challenge was resolved through the inclusion of ${ }^{137} \mathrm{Cs}$ (Le Cloarec et al. 2007). Under certain environmental conditions (e.g. under acidic and ammonium-rich conditions or in saline environments), ${ }^{137} \mathrm{Cs}$ is known to be chemically mobile and can be removed from soils in solution (Parsons and Foster 2011; Appleby et al. 2019).

However, the basic two-box approach has been challenged (Walling 2013a). To avoid potential differences in the ${ }^{7} \mathrm{Be} /{ }^{210} \mathrm{~Pb}_{\text {ex }}$ ratios measured in rainfall and in recently eroded sediment, Evrard et al. (2016) recently proposed the assay of sediment collected in overland flow or using 'edgeof-field' samplers to characterize the source signature, instead of analysing rainfall. Another critique was that sub-surface material is theoretically sheltered from ${ }^{7} \mathrm{Be}$ fallout (Walling 2013a). However, Hancock et al. (2014) demonstrated that, although this may be true for vertical sub-surface sources (e.g. gully sides and vertical channel banks), horizontal sub-surface sediment sources (e.g. gully floor material) may be exposed to rainfall and labelled with ${ }^{7} \mathrm{Be}$ and ${ }^{210} \mathrm{~Pb}$ ex , whilst being depleted in ${ }^{137} \mathrm{Cs}$ as shown earlier by Wallbrink and Murray (1993). To reflect this diversity in field settings, a distribution modelling approach using the concentrations of ${ }^{7} \mathrm{Be},{ }^{137} \mathrm{Cs}$ and ${ }^{210} \mathrm{~Pb}_{\mathrm{ex}}$ measured in both source and sediment material was proposed to quantify the contributions of four source endmembers (i.e. recently eroded surface, re-suspended surface, recently eroded sub-surface and re-suspended sub-surface) to sediment transiting the river (Evrard et al. 2016; Le Gall et al. 2018). However, one of the limitations of this approach is that it does not calculate an age or a residence/transit time.

Gellis et al. (2016) apportioned sediment sources (channel versus land surface) using ${ }^{210} \mathrm{~Pb}_{\mathrm{ex}}$ and the age $(<1$ year) of fine-grained $(<63 \mu \mathrm{m})$ suspended and bed sediment using ${ }^{7} \mathrm{Be}$ for 99 wadeable streams of the American Midwest. The findings suggested that channel sources dominate and that the age of the bed and suspended sediment ranged from 0 to 174 days. Both Matisoff et al. (2005) and Gellis et al. (2016) acknowledged that a shortcoming of their approach was that they could not determine whether the channel-derived sediment originated from streambanks or from older surface- 
derived sediment that had been in channel storage for several decades. In a follow-up study, Gellis et al. (2019) apportioned the sources of sediment in the agricultural Walnut Creek watershed, IA, USA, into channel banks and surface-derived sediment (pasture, prairie, cropland and unpaved roads) using sediment fingerprinting (elemental analysis) and fallout radionuclides $\left({ }^{210} \mathrm{~Pb}_{\mathrm{ex}}\right.$ and $\left.{ }^{7} \mathrm{Be}\right)$ to determine the age of the surfacederived portion of sediment (Fig. 7). A basic understanding of the hydrologic system is important in addressing possible problems with sediment residence times. For example, if a catchment is transport dominant, few sites of sediment deposition may occur, and sediment residence times may be low. In catchments that are transport limited, sites of deposition may be frequent and residence times higher. Geomorphic reconnaissance of the catchment (e.g. approaches such as Fitzpatrick et al. 2006) may be useful in qualifying the transport features of a catchment. Based on the different methods outlined above, fine-grained sediment transit and residence times are gradually being estimated around the world (Table 1).

Alongside dating fine-grained sediment in transit, current research continues to date fluvial sediment over the last two centuries using time specific tracers and the half-life of fallout radionuclides (Table 1). Time-specific tracers represent a given time or time period which can be natural or human caused. For example, ${ }^{137} \mathrm{Cs}$ was delivered to the Earth's surface following above ground thermonuclear bomb tests from the 1950 s to 1970 s with peak activity around $1963-1964$. Generally, when delivered to the Earth's surface, ${ }^{137} \mathrm{Cs}$ binds strongly with fine-grained sediment and becomes a time marker of surface sediment, although some recent work identifies settings when this assumption is open to challenge (Appleby et al. 2019). Fluvial sediment that contains ${ }^{137} \mathrm{Cs}$ activity indicates that a portion of the sediment was on the Earth's surface during the period 1950s-1970s. Other time markers may dose sediment during a particular time period marked by an event such as an industrial waste disposal or discharge (Skalak and Pizzuto 2010), toxic spills (Lauer and Vengosh 2016) or radioactive spills (Graf 1996).

Techniques that can provide a chronology for timescales over the last 2-3 centuries are listed in Table 2 . This is not an exhaustive list, and it is assumed that, because conventional ${ }^{14} \mathrm{C}$ dating cannot be used for the last ca. 250 years due to fossil fuel combustion, only its fallout history after nuclear weapons testing could provide a practical chronology over more recent decades. However, alternatives (e.g. ${ }^{137} \mathrm{Cs}$, ${ }^{241} \mathrm{Am}$ ) are far more frequently used for dating sedimentary sequences, often in combination with ${ }^{210} \mathrm{~Pb}$. Dating of recent sediments often benefits from changes in source properties over time; so, a factor that makes these changes a limitation for fingerprinting can become an advantage for dating. Spherical carbonaceous particles (SCPs) and heavy metals (HMs), for example, are both linked to industrialisation and atmospheric pollution. They have a fallout history in many industrialized countries that is well documented and can be used to identify known time periods, with SCPs first appearing in independently dated UK lake sediments around 1850 and the first notable rise in HMs around 1865. However, neither can be used for source tracing as concentrations of SCPs and HMs in potential sources (e.g. topsoil) will have changed throughout the history of fallout. Similar problems are encountered in using ${ }^{137} \mathrm{Cs},{ }^{241} \mathrm{Am}$ and ${ }^{14} \mathrm{C}$. All have a known temporal fallout history associated with atmospheric thermonuclear weapons testing and/or nuclear accidents.
Table 1 Sediment ages calculated with fallout radionuclides reported in the literature

\begin{tabular}{|c|c|c|c|}
\hline Study area & Tracers & Sediment age(s) & Reference \\
\hline Murrumbidgee R. (Australia) & ${ }^{210} \mathrm{~Pb}_{\mathrm{ex}}$ & $10 \pm 5$ years & $\begin{array}{l}\text { Wallbrink et al. } \\
\text { (1998) }\end{array}$ \\
\hline $\begin{array}{l}\text { Old Woman Creek (OH, } \\
\text { USA) }\end{array}$ & ${ }^{7} \mathrm{Be},{ }^{210} \mathrm{~Pb}_{\mathrm{ex}}$ & 46-79 days & Matisoff et al. (2005) \\
\hline \multicolumn{4}{|l|}{ Weeks Bay (AL, USA) } \\
\hline \multicolumn{4}{|l|}{ South Slough (OR, USA) } \\
\hline Seine R. (France) & $\begin{array}{c}{ }^{7} \mathrm{Be},{ }^{210} \mathrm{~Pb}_{\mathrm{ex}}, \\
{ }^{137} \mathrm{Cs}\end{array}$ & $\begin{array}{l}<365 \text { days; } \\
\quad 4800-30,000 \text { years }\end{array}$ & $\begin{array}{l}\text { Le Cloarec et al. } \\
\quad(2007)\end{array}$ \\
\hline Cointzio R. (Mexico) & $\begin{array}{l}{ }^{7} \mathrm{Be},{ }^{210} \mathrm{~Pb}_{\mathrm{ex}}, \\
{ }^{137} \mathrm{Cs}\end{array}$ & $\begin{array}{l}\text { 50-200 days; } \\
5000-23,300 \text { years }\end{array}$ & Evrard et al. (2010) \\
\hline Pleasant Valley (WI, USA) & ${ }^{7} \mathrm{Be},{ }^{210} \mathrm{~Pb}_{\mathrm{ex}}$ & $123 \pm 12$ to $322 \pm 144$ days & Lamba et al. (2015) \\
\hline Houay Pano (Laos) & ${ }^{7} \mathrm{Be},{ }^{210} \mathrm{~Pb}_{\mathrm{ex}}$ & $8-158$ days & Ribolzi et al. (2016) \\
\hline Midwest (USA) & ${ }^{7} \mathrm{Be}$ & $68 \%$ of streams $<100$ days & Gellis et al. (2017) \\
\hline Louroux R. (France) & ${ }^{7} \mathrm{Be},{ }^{210} \mathrm{~Pb}_{\mathrm{ex}}$ & $0-215$ days & Le Gall et al. (2017a) \\
\hline Walnut Creek (IA, USA) & ${ }^{7} \mathrm{Be},{ }^{210} \mathrm{~Pb}_{\mathrm{ex}}$ & 44-208 days; $1-58$ years & Gellis et al. (2019) \\
\hline $\begin{array}{l}\text { White Clay Creek (PA, } \\
\text { USA) }\end{array}$ & ${ }^{7} \mathrm{Be},{ }^{210} \mathrm{~Pb}_{\mathrm{ex}}$ & $1-110$ days & Karwan et al. (2018) \\
\hline
\end{tabular}


Fig. 7 General model of sediment transit and residence times (after Gellis et al. 2019)

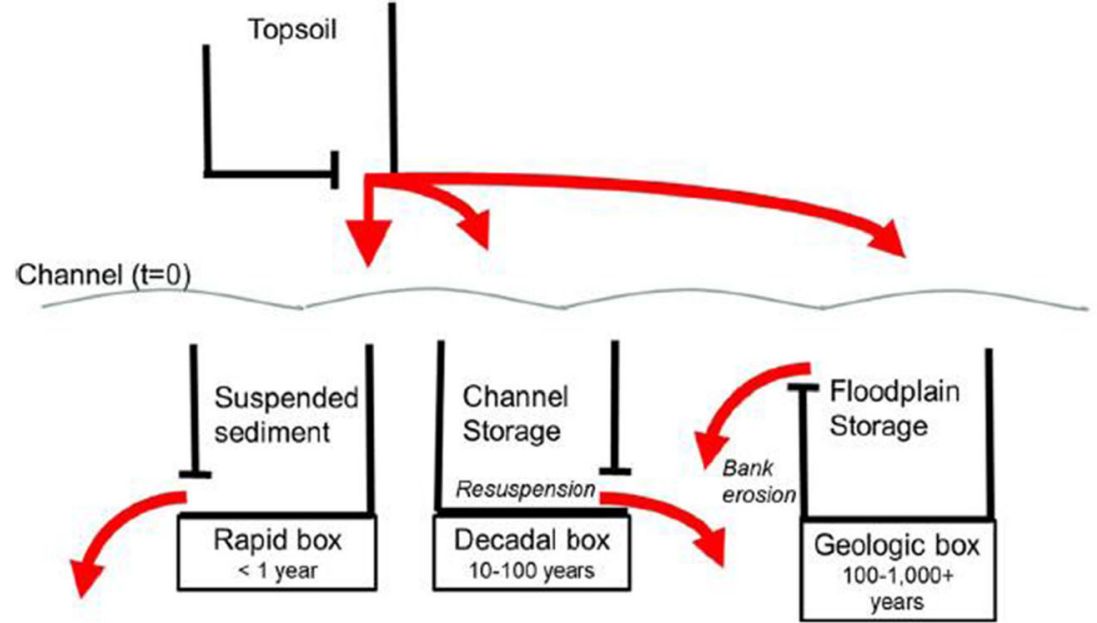

Several long-lived radionuclides such as ${ }^{238} \mathrm{U}$ and ${ }^{235} \mathrm{U}$ may have become enriched in agricultural topsoil where phosphate fertilizers are used as the North African rock phosphate from which a significant amount of fertilizer is derived often contains significant amounts of radioactive uranium (Sahu et al. 2014; Hassan et al. 2017). Neither of these isotopes or their daughters would be useful for fingerprinting over recent timescales in the same way that phosphorus could not be used directly for fingerprinting.

Failure of ${ }^{210} \mathrm{~Pb}_{\mathrm{ex}}$ and ${ }^{137} \mathrm{Cs}$ to provide a reliable chronology for lake, reservoir and floodplain sediments over the last $100-150$ years has also been reported. ${ }^{137} \mathrm{Cs}$ is generally

Table 2 Potential dating techniques for sediment over the time ranges from decades to centuries

\begin{tabular}{|c|c|c|c|c|c|}
\hline Dating method & $\begin{array}{l}\text { Half-life (years } \\
\text { except where stated) }\end{array}$ & $\begin{array}{l}\text { Recent timescale } \\
\text { (years to decades) }\end{array}$ & $\begin{array}{l}\text { Historic timescale } \\
\text { (100s years) }\end{array}$ & Source & Reference \\
\hline${ }^{7} \mathrm{Be}$ & 53.3 days & $\sim 1$ year & & $\begin{array}{l}\text { Naturally produced } \\
\text { radionuclide }\end{array}$ & $\begin{array}{l}\text { Gellis et al. }(2017,2018) \\
\text { Matisoff et al. (2005) }\end{array}$ \\
\hline${ }^{14} \mathrm{C}$ & 5730 & From 1954 & & & $\begin{array}{l}\text { McGeehin et al. (2004); Hua } \\
\text { (2009) }\end{array}$ \\
\hline${ }^{241} \mathrm{Am}$ & 432.2 & From 1954 & & Nuclear bomb fallout & $\begin{array}{l}\text { Appleby et al. (1991); Arnaud } \\
\text { et al. (2006) }\end{array}$ \\
\hline${ }^{137} \mathrm{Cs}$ & 30.2 & From 1954 & & $\begin{array}{l}\text { Nuclear bomb fallout } \\
\text { and nuclear accidents }\end{array}$ & $\begin{array}{l}\text { Walling and Foster (2016); } \\
\text { Foster et al. (2006) }\end{array}$ \\
\hline${ }^{32} \mathrm{Si}$ & $\sim 153$ & & Last 500 years & Cosmogenic nuclide & $\begin{array}{l}\text { Fifield and Morgenstern } \\
\text { (2009); Finch et al. (2016) }\end{array}$ \\
\hline${ }^{210} \mathrm{Pbex}$ & 22.3 & & Last $100-150$ years & U-238 decay series & $\begin{array}{l}\text { Appleby (2001); Walling and } \\
\text { Foster (2016) }\end{array}$ \\
\hline Luminescence & & & $\begin{array}{l}<\text { 100-late } \\
\text { Quaternary }\end{array}$ & $\begin{array}{l}\text { Electron capture in quartz } \\
\text { and feldspar sands }\end{array}$ & $\begin{array}{l}\text { Thomas et al. (2007); } \\
\text { Sawakuchi et al. (2016) }\end{array}$ \\
\hline $\begin{array}{l}\text { Varve } \\
\text { chronologies }\end{array}$ & & & Holocene & $\begin{array}{l}\text { Limited to environments } \\
\text { with alternate seasonal } \\
\text { freezing and thawing }\end{array}$ & \\
\hline \multirow[t]{2}{*}{ Heavy metals } & & & Various & $\begin{array}{l}\text { Atmospheric pollution, } \\
\text { mining, smelting }\end{array}$ & $\begin{array}{l}\text { Jones et al. (1991); Foster and } \\
\text { Charlesworth (1996) }\end{array}$ \\
\hline & & & since ca. 1800 & $\begin{array}{l}\text { urban transport related, } \\
\text { toxic spillages }\end{array}$ & $\begin{array}{l}\text { Maina et al. (2019); Lauer and } \\
\text { Vengosh (2016) }\end{array}$ \\
\hline SCPs & & & First rise ca. 1850 & $\begin{array}{l}\text { Industrial atmospheric } \\
\text { pollution }\end{array}$ & $\begin{array}{l}\text { Rose (2002); Rose and } \\
\text { Appleby (2005) }\end{array}$ \\
\hline Tephra & & & Late Holocene & Volcanic eruptions & $\begin{array}{l}\text { Horowitz et al. (1995); Lowe } \\
2011\end{array}$ \\
\hline Pollen & & & Last ca. 300 years & $\begin{array}{l}\text { Local landscaping/vegetation } \\
\text { disturbance records }\end{array}$ & $\begin{array}{l}\text { Schottler and Engstrom } \\
\text { (2006); Pittam et al. (2009) }\end{array}$ \\
\hline
\end{tabular}


considered to be more chemically mobile in sediments than ${ }^{210} \mathrm{~Pb}$ (Appleby 2001; Fig. 4) and has been reported to be transported in the dissolved phase in significant quantities to lakes (Appleby et al. 2019). However, some lakes appear to have lower ${ }^{210} \mathrm{~Pb}_{\mathrm{ex}}$ activities and inventories than predicted (Pittam et al. 2009), for which no plausible explanation has yet been found. Several factors, including acidic and ammonium-rich conditions, appear to favour ${ }^{137} \mathrm{Cs}$ remobilisation as do highly saline environments in coastal environments (Foster et al. 2006). However, more mundane factors such as dredging can lead to the failure of a chronology unless the management history of individual sites is well documented. ${ }^{210} \mathrm{~Pb}$ dating has been reported to fail in lakes where surface runoff is negligible and thus sediment inputs are minimal, such as groundwater-dominated lakes in Florida as the parent isotope is present in groundwater and leads to ${ }^{210} \mathrm{~Pb}_{\mathrm{ex}}$ activities lower than that predicted from the presence of its parent (Brenner et al. 2004). ${ }^{32} \mathrm{Si}$ dating works in the same way as conventional ${ }^{14} \mathrm{C}$ dating as it is a cosmogenic nuclide which falls out continuously and assimilates in the exoskeletons of organisms that use $\mathrm{Si}$ rather than $\mathrm{Ca}$ as the basic building block (diatoms). It is likely therefore to require the same calibration between ${ }^{32} \mathrm{Si}$ age and calendar age as ${ }^{14} \mathrm{C}$. This is likely to prove much more problematic as other forms of silica are much rarer than the tree rings frequently used to calibrate ${ }^{14} \mathrm{C}$, but calibration may be possible against varved lake sediment sequences (Fifield and Morgenstern 2009). Tephra and exotic pollen rain can be regional and/or local in geographical extent, but there are searchable online databases for tephra such as Tephrabase (https://www.tephrabase.org/) that can find dates and locations of eruptions and their chemical signatures. Potential exotic pollen will normally require access to local estate records in order to establish planting history (e.g. Pittam et al. 2009) or make use of known periods of dramatic vegetation change (Schottler and Engstrom 2006). Varve chronologies are limited to cold climate environments where sedimentation couplets are produced alternately by spring snowmelt bringing minerogenic sediment into the lake basin and autumn dieback when organic matter is deposited. If it can be assumed that the varves are annual, the method can be used to help calibrate other dating methods (Fifield and Morgenstern 2009). The presence of coarse sedimentary layers relating to extreme precipitation events can also be used to help fine tune radiometric chronologies (Foster et al. 2007, 2019) whilst particle size analysis can help provide information on long-term palaeoflood records (Schillereff et al. 2014) as particle size distributions are rarely modified by post-depositional diagenesis. More recently, Foucher et al. (2020) have used high-resolution CT scanning to identify flood layers in sediment cores rather than stratigraphic or particle size data.

\subsection{Extending applications to other sediment- associated priority pollutants}

Trace elements and organic pollutants have drawn attention as sediment-associated priority pollutants, and the identification of their source is therefore essential. The fine particle size fractions (typically $<63 \mu \mathrm{m}$ ) of sediment are known to be enriched in numerous contaminants (Owens et al. 2005), and an increasing number of studies are applying sediment fingerprinting techniques to quantify the source contributions or the dynamics of sediment-associated pollutants (Froger et al. 2018). For instance, Le Gall et al. (2018) analysed the fallout radionuclide contents in contaminated sediment mobilized during the exceptional flood on the Seine River in Paris (France) in 2016 and showed that this event mobilized, in particular, older contaminated sediment from an upstream tributary. Past contaminant concentrations are often reconstructed based on the analysis of sediment cores collected from lakes or in floodplains (Macklin et al. 1997; Desmet et al. 2012; Van Metre and Horowitz 2013). Importantly, the comparison of contamination levels in sediment samples collected at several locations in the river channel should systematically take into account the potential differences in particle size between samples and the local background levels when sediment-associated metals are investigated (Matys Grygar and Popelka 2016). Normalising the concentrations with geochemically insoluble elements may provide an alternative to sieving the samples to a specific particle size. A recent study conducted in a river of the Czech Republic suggested that $\mathrm{Fe}$ is preferable to $\mathrm{Al}$ and $\mathrm{Ti}$ for conducting such a normalisation (Tůmová et al. 2019). The analysis of metal contents in sediment is associated with several methodological debates associated with the use of total or partial digestion protocols (Dabrin et al. 2014). To avoid these problems and this timeconsuming sample preparation, the increasing use of nondestructive X-ray fluorescence techniques may increase our capacity to provide high-resolution elemental profiles in sediment core profiles. However, these alternative techniques require demanding calibration protocols to provide absolute concentrations of sediment-associated contaminants (Lee et al. 2018).

Far fewer studies (Zou et al. 2015) have addressed the sources of organic pollutants such as polycyclic aromatic hydrocarbons (PAH) - a large group of persistent organic pollutants, which are among the most important priority pollutants based on a combination of their frequency, toxicity and potential for human exposure (ATSDR 2015) or polychlorinated biphenyls (PCBs) (Mourier et al. 2014). Combining multiple tools, including innovative methods (i.e. PAH correlations and sediment fingerprinting using fallout radionuclides), is essential to discriminate between legacy and contemporary PAH sources at the catchment scale (Froger et al. 2019). The main concerns regarding source 
identification using PAH are the similarities between multiple PAH sources ( $\mathrm{Li}$ et al. 2003), the high photolytic degradation rates of PAH compounds, especially for those lighter compounds which may hamper their discrimination (Kim et al. 2009) and the uncertainties related to their potential nonconservative behaviour.

The ongoing development of novel techniques to conduct rapid, low-cost and non-destructive measurements with a high resolution on sediment core profiles will also significantly increase our capacities to quantify and understand the transfer of particle-bound contaminants. Recently, the use of hyperspectral sensors provided a way to analyse chlorophyll $a$ to quantify changes in burnt organic matter levels in a lake draining a catchment exposed to forest fires (Van Exem et al. 2018). Collaborations between palaeoclimatologists, geomorphologists and hydrologists will stimulate novel methods and corresponding findings (Jacq et al. 2019).

\subsection{Incorporation of supportive spatial information to aid un-mixing model parameterisation}

Whilst applications of sediment source fingerprinting procedures increase worldwide, there remains a need to explore the scope for enhancing conventional fingerprints and especially using additional tracers linking to the fundamental physical controls for sediment mobilisation and delivery and their potential spatial variation at landscape scale. In river drainage basins, chemical weathering plays an important role in geochemical cycles (Ohta and Arai 2007; Li and Yang 2010; Shao et al. 2012; Guo et al. 2018). As a result, the eroded materials transferred by rivers preserve valuable information on land surface weathering, erosional status and processes and climatic variation. In particular, it is possible to explore the intensity of chemical weathering based on the information recorded in river sediment (Ohta and Arai 2007; Goldberg and Humayun 2010; Carter et al. 2015; Guo et al. 2018). Here, weathering indices can be used to indicate the intensity of chemical weathering processes using the degree of elemental mobility caused by the depletion of mobile relative to immobile elements during recycling (Price and Velbel 2003; Nadlonek and Bojakowska 2018). Because weathering indices reflect complex interactions between the climate regime, lithology, soil development, tectonism, topography, vegetation cover and anthropogenic activity including land use (Gibbs 1970; Meybeck 1987; Oliva et al. 2003; Li and Yang 2010; Shao et al. 2012; Négrel et al. 2015), their consideration as potential sediment source tracers provides a means for physically grounded source discrimination (Motha et al. 2003; Mohammadi Raigani et al. 2019; Nosrati et al. 2019). To date, however, limited research effort has been invested in the scope for using weathering indices alongside more conventional fingerprint properties. Instead, much research has continued to focus on testing different combinations of conventional tracers in composite fingerprints and the corresponding potential contrasts in predicted source apportionment (Owens et al. 2016; Collins et al. 2017; Smith et al. 2018; Tang et al. 2019). Nevertheless, weathering indices might provide useful tracers for source discrimination and apportionment since they reflect the propensity for soil erosion, meaning that a sub-basin with more exposed highly erodible formations might be expected to have more sediment mobilisation (Garzanti et al. 2016).

There are numerous weathering indices (Table 3 ) such as enrichment factors and indices of geochemical maturity (e.g. the resistant index, the oxidative index) based on soil and sediment geochemistry, and these can be used to interpret weathering history. CIA (chemical index of alteration) is potentially useful as a tracer since it provides a basis for identifying chemical changes caused by weathering of aluminosilicate minerals (Motha et al. 2003; Haddadchi et al. 2013; Owens et al. 2016). In general, higher CIA values suggest more weathering of silicates (Shao et al. 2012). A mean CIA value for the suspended sediment in select global rivers has been estimated at 72.1 ( $\mathrm{Li}$ and Yang 2010), compared with a corresponding value of 79.7 for the upper continental crust (Taylor and McLennan 1985).

Previous literature demonstrates that some early work by Motha et al. (2003) determining the sources of suspended sediment in a forested catchment, in south-eastern Australia, concluded that the CIA was useful for separating gravelsurfaced roads from three other sources categorized as undisturbed forest, harvested areas and ungravelled roads. More recently, Nosrati et al. (2019) showed that spatial variation in some weathering indices was consistent with corresponding spatial variation in suspended sediment concentrations measured for different catchment spatial sources during runoff events in a mountainous setting in Iran. On this basis, geochemical tracers were combined with the weathering indices to fingerprint sub-basin spatial suspended sediment sources. Similarly, Mohammadi Raigani et al. (2019) used a spatial sediment source fingerprinting approach to provide sediment provenance information in a mountainous agricultural catchment in western Iran. This study suggested that weathering indices potentially offer useful information for helping inform the pre-selection of fingerprint properties.

Composite signatures should comprise different types of tracers to maximize discriminatory efficiency. In the context of using weathering indices to provide supportive spatial information for source discrimination and apportionment, it is advisable that any geochemical tracers included are not also used in the estimation of any weathering index selected for a final signature, since the requirement for using independent tracers in composite fingerprints should not be overlooked. As an example, Fig. 8 compares the discriminatory efficiency of two composite signatures for discriminating sub-basin spatial suspended sediment sources from the recent study of Nosrati 
Table 3 Information on chemical weathering indices

\begin{tabular}{|c|c|c|}
\hline Chemical weathering index & Formulation* & References \\
\hline $\begin{array}{l}\text { Chemical index of alteration } \\
\text { (CIA) }\end{array}$ & $\mathrm{Al}_{2} \mathrm{O}_{3} /\left(\mathrm{Al}_{2} \mathrm{O}_{3}+\mathrm{CaO}+\mathrm{Na}_{2} \mathrm{O}+\mathrm{K}_{2} \mathrm{O}\right) \times 100$ & $\begin{array}{l}\text { Nesbitt and Young (1982); Ohta } \\
\text { and Arai (2007); Li and Yang (2010); } \\
\text { Buggle et al. (2011); Shao et al. (2012); } \\
\text { Guo et al. (2018). }\end{array}$ \\
\hline $\begin{array}{l}\text { Modified weathering potential } \\
\text { index (MWPI) }\end{array}$ & $\begin{array}{l}\left(\left(\mathrm{K} 2 \mathrm{O}+\mathrm{Na}_{2} \mathrm{O}+\mathrm{CaO}+\mathrm{MgO}\right) /\left(\mathrm{SiO}_{2}+\mathrm{Al}_{2} \mathrm{O}_{3}+\mathrm{Fe}_{2} \mathrm{O}_{3}\right.\right. \\
\left.\left.\quad+\mathrm{K}_{2} \mathrm{O}+\mathrm{Na}_{2} \mathrm{O}+\mathrm{CaO}+\mathrm{MgO}\right)\right) \times 100\end{array}$ & Vogel (1975) \\
\hline $\begin{array}{l}\text { Weathering index of Parker } \\
\text { (WIP) }\end{array}$ & $\left(2 \mathrm{Na}_{2} \mathrm{O} / 0.35+\mathrm{MgO} / 0.9+2 \mathrm{~K}_{2} \mathrm{O} / 0.25+\mathrm{CaO} / 0.7\right) \times 100$ & $\begin{array}{l}\text { Parker (1970); Price and Velbel (2003); } \\
\text { Guo et al. }(2017,2018) \text {. }\end{array}$ \\
\hline Product index $(\mathrm{PI})$ & $\left.\left.100 * \mathrm{SiO}_{2} / \mathrm{SiO}_{2}+\mathrm{TiO}_{2}+\mathrm{Fe}_{2} \mathrm{O}_{3}+\mathrm{Al}_{2} \mathrm{O}_{3}\right)\right] \times 100$ & Ruxton (1968) \\
\hline $\begin{array}{l}\text { Chemical index of weathering } \\
\text { (CIW) }\end{array}$ & $\mathrm{Al}_{2} \mathrm{O}_{3} /\left(\mathrm{Al}_{2} \mathrm{O}_{3}+\mathrm{CaO}+\mathrm{Na}_{2} \mathrm{O}\right) \times 100$ & Harnois (1988) \\
\hline $\begin{array}{l}\text { Plagioclase index of alteration } \\
\text { (PIA) }\end{array}$ & $\left(\mathrm{Al}_{2} \mathrm{O}_{3}-\mathrm{K}_{2} \mathrm{O}\right) /\left(\mathrm{Al}_{2} \mathrm{O}_{3}+\mathrm{CaO}+\mathrm{Na}_{2} \mathrm{O}-\mathrm{K}_{2} \mathrm{O}\right) \times 100$ & $\begin{array}{l}\text { Fedo et al. (1995); Price and Velbel (2003); } \\
\text { Buggle et al. (2011) }\end{array}$ \\
\hline Recycling ratio (RI) & CIA/WIP & Garzanti et al. (2016); Guo et al. $(2017,2018)$ \\
\hline $\begin{array}{l}\text { Silica-alumina ratio index } \\
\text { (SA) or Ruxton ratio (RR) }\end{array}$ & $\mathrm{SiO}_{2} / \mathrm{Al}_{2} \mathrm{O}_{3}$ & Ruxton (1968) \\
\hline Vogt ratio (VR) & $\left(\mathrm{Al}_{2} \mathrm{O}_{3}+\mathrm{K}_{2} \mathrm{O}\right) /\left(\mathrm{MgO}+\mathrm{CaO}+\mathrm{Na}_{2} \mathrm{O}\right)$ & Guan et al. (2001) \\
\hline Si-Ti Index & $\begin{array}{l}\left(\mathrm{SiO}_{2} / \mathrm{Al}_{2} \mathrm{O}_{3}\right) /\left(\left(\mathrm{SiO}_{2} / \mathrm{TiO}_{2}\right)+\left(\mathrm{SiO}_{2} / \mathrm{Al}_{2} \mathrm{O}_{3}\right)+\right. \\
\left.\quad\left(\mathrm{Al}_{2} \mathrm{O}_{3}+\mathrm{TiO}_{2}\right)\right)\end{array}$ & Jayawardena and Izawa (1994) \\
\hline Silica-sesquioxide ratio $(\mathrm{Kr})$ & $\mathrm{SiO}_{2} /\left(\mathrm{Al}_{2} \mathrm{O}_{3}+\mathrm{Fe}_{2} \mathrm{O}_{3}\right)$ & Moignien (1966) \\
\hline $\begin{array}{l}\text { Alumina-sodium to calcium } \\
\text { oxide ratio (ACN) }\end{array}$ & $\mathrm{Al}_{2} \mathrm{O}_{3} /\left(\mathrm{Al}_{2} \mathrm{O}_{3}+\mathrm{K}_{2} \mathrm{O}+\mathrm{Na}_{2} \mathrm{O}\right)$ & Harnois and Moore (1988) \\
\hline $\begin{array}{l}\text { Alumina to potassium-sodium } \\
\text { oxide ratio }(\mathrm{AKN})\end{array}$ & $\mathrm{Al}_{2} \mathrm{O}_{3} /\left(\mathrm{K}_{2} \mathrm{O}+\mathrm{Na}_{2} \mathrm{O}\right)$ & Harnois and Moore (1988) \\
\hline Alkaline ratio (ALK) & $\left(\mathrm{K}_{2} \mathrm{O} /\left(\mathrm{K}_{2} \mathrm{O}+\mathrm{Na}_{2} \mathrm{O}\right)\right) \times 100$ & Harnois and Moore (1988) \\
\hline Hydration coefficient $(\mathrm{Hc})$ & $\mathrm{H}_{2} \mathrm{O} /\left(\mathrm{K}_{2} \mathrm{O}+\mathrm{Na}_{2} \mathrm{O}+\mathrm{CaO}+\mathrm{MgO}\right)$ & Ng et al. (2001) \\
\hline Leaching coefficient (Lc) & $\mathrm{SiO}_{2} /\left(\mathrm{K}_{2} \mathrm{O}+\mathrm{Na}_{2} \mathrm{O}+\mathrm{CaO}+\mathrm{MgO}\right)$ & Ng et al. (2001) \\
\hline Residual coefficient $(\mathrm{Rc})$ & $\left(\mathrm{Al} 2 \mathrm{O}_{3}+\mathrm{Fe}_{2} \mathrm{O}_{3}\right) /\left(\mathrm{K}_{2} \mathrm{O}+\mathrm{Na}_{2} \mathrm{O}+\mathrm{CaO}+\mathrm{MgO}\right)$ & $\mathrm{Ng}$ et al. (2001) \\
\hline Sesquioxide content (SOC) & $\mathrm{Al}_{2} \mathrm{O}_{3}+\mathrm{Fe}_{2} \mathrm{O}_{3}$ & Irfan (1996) \\
\hline $\mathrm{R}_{2} \mathrm{O}_{3}$ ratio & $\begin{array}{l}\mathrm{Al}_{2} \mathrm{O}_{3}+\mathrm{Fe}_{2} \mathrm{O}_{3}+\mathrm{MgO}+\mathrm{K}_{2} \mathrm{O}+\mathrm{Na}_{2} \mathrm{O}+ \\
\left.\quad \mathrm{CaO}+\mathrm{TiO}_{2}+\mathrm{P}_{2} \mathrm{O}_{5}+\mathrm{ZnO}+\mathrm{MnO}+\mathrm{Rb}_{2} \mathrm{O}\right) / \mathrm{MgO}\end{array}$ & Duzgoren-Aydin et al. (2002) \\
\hline Index of desilication (ID) & $\mathrm{SiO}_{2} / \mathrm{R}_{2} \mathrm{O}_{3}$ & Singh et al. (1998) \\
\hline Loss of ignition (LOI) & LOI content in weight of sample heated in a range $900-1000{ }^{\circ} \mathrm{C}$ & Sueoka et al. (1985) \\
\hline
\end{tabular}

*All the weathering indices are calculated based on molecular weights of elemental oxides (Garzanti 2016), corrected for Ca by considering the ratio of $\mathrm{CaO}$ to $\mathrm{Na}_{2} \mathrm{O}$ (McLennan 1993)

et al. (2019). The two signatures comprised the combined use of weathering indices and geochemical tracers (CIA, WIP, IR, $\mathrm{Cu}, \mathrm{Fe}, \mathrm{Mn}, \mathrm{Sr}, \mathrm{Z})$ and geochemical tracers only $(\mathrm{Cu}, \mathrm{Fe}, \mathrm{Mn}$, $\mathrm{Sr}, \mathrm{Zn})$. In this case, the results clearly demonstrated the increasing discriminatory power by adding the weathering indices. Future research should expand assessment of the application of weathering indices in combination with more conventional fingerprint properties for additional hydroclimatic settings. With regards fingerprint property conservation, longitudinal sediment sampling in large drainage basins would also permit weathering indices to be used to explore any potential evolution of tracer transformation risks across scales and, again, this should be explored in future work.

However, it is important to acknowledge that care is needed in interpreting geochemical indices. Differences in rock chemical composition, especially those that have been affected by localized changes such as igneous intrusions or other metamorphic processes, can lead to differential deterioration rates not only across different lithologies but also within similar lithologies (Sayyed 2014). Furthermore, exposure to environmental stresses, such as temperature changes and precipitation, can lead to both localized strengthening of the rock surface (e.g. the formation of crusts and case hardening; McAlister et al. (2003); Viles and Goudie (2004)) and deterioration through the preferential draw-through of internal moisture (Mol 2014) and exposure to increased temperatures (Smith et al. 2011b). These localized alterations in the mineral composition, as well as the differential deterioration of the rock, surfaces as a function of mineral composition and exposure to environmental stresses (Weiss et al. 2004). Therefore, 


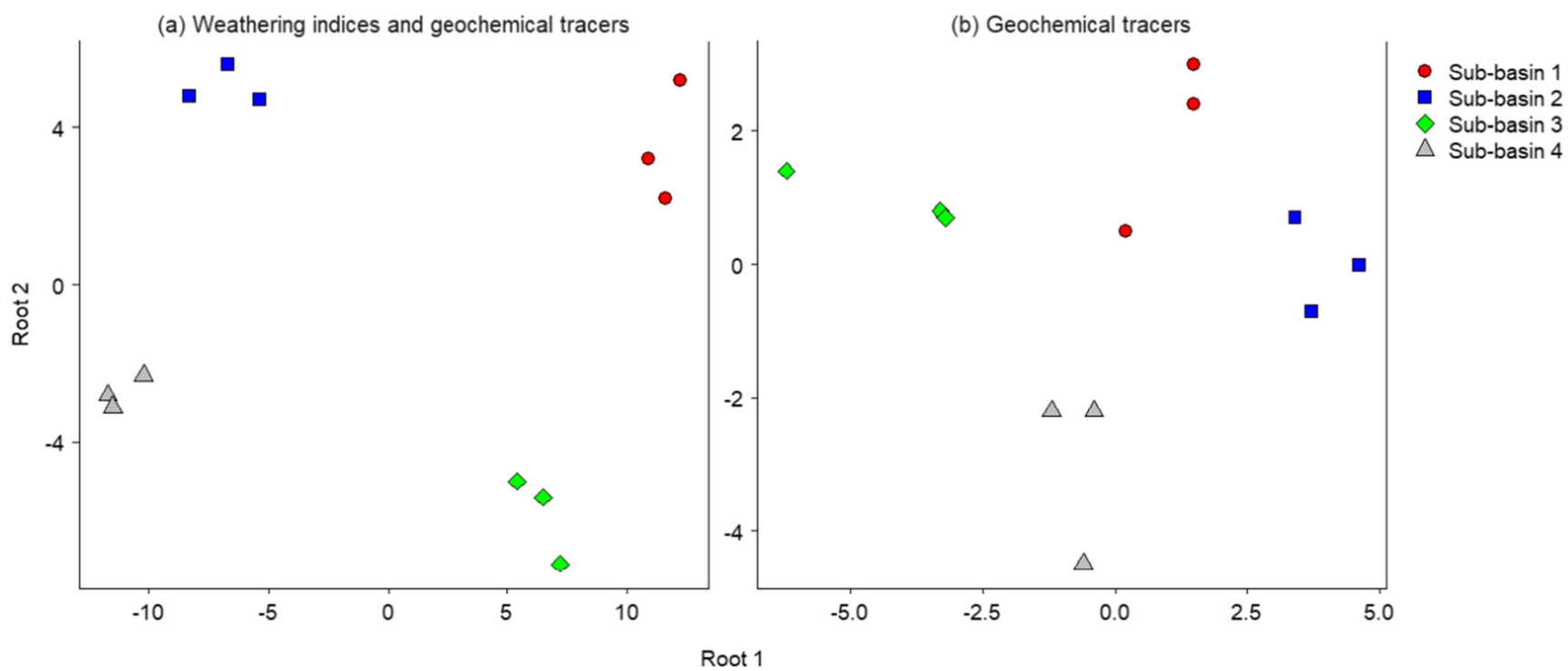

Fig. 8 Visual comparison of the discrimination of tributary subcatchment spatial sediment sources using two different composite signatures: left hand plot—weathering indices and geochemical tracers

a combined approach of geological mapping (Laceby et al. 2015; Pulley et al. 2017a, 2017b) geomorphological assessments of rock deterioration (Mol and Viles 2012; Pola et al. 2014) and landscape connectivity (Navratil et al. 2012) is required to investigate potential sediment provenance, further diagenesis and material weathering post-removal from the parent rock. Significant geomorphological events (e.g. landslides; Pickup and Marks 2000) also need to be mapped. This does, however, open up new avenues of investigation, where sedimentologists work closely with geologists and geomorphologists.

\subsection{Application in aeolian sediment provenance studies}

Aeolian sediments, including wind storm dust, sand and loess, are emitted from land surfaces in a range of different climatic settings. These sediments can smother crops, reduce visibility thereby impacting on traffic safety and result in long-term health problems due to a decline in air quality, especially in urban areas (Goossens 2003). A range of techniques has been used to investigate key dust sources for targeting remedial action including, amongst others, data mining with ensemble or individual models (Gholami et al. 2020a, b), remote sensing (Filonchyk et al. 2018), comparison of strontium $\left({ }^{87} \mathrm{Sr} /{ }^{86} \mathrm{Sr}\right.$ ) or neodymium $\left({ }^{143} \mathrm{Nd} /{ }^{144} \mathrm{Nd}\right.$ ) ratios (Yang et al. 2008; Saitoh et al. 2011), rare earth elements (Dukes et al. 2018) and detrital zircon ages or heavy mineral composition (Garzanti et al. 2013; Fyhn et al. 2019). Since 2016, however, there has been a growing interest in applying sediment source tracing procedures using linear mixing models (Liu et al. 2016; Gholami et al. 2017a; Wang et al. 2017; Zhao et al. 2020; Niu et al.
(CIA, WIP, IR, $\mathrm{Cu}, \mathrm{Fe}, \mathrm{Mn}, \mathrm{Sr}, \mathrm{Zn}$ ) and right hand plot—geochemical tracers only (Cu, Fe, Mn, Sr, Zn) (after Nosrati et al. 2019)

2020), Monte Carlo simulation (Gholami et al. 2019b), Bayesian approaches (Gholami et al. 2017b, 2019a) and generalized likelihood uncertainty estimation (GLUE) model (Behrooz et al. 2019; Telfer et al. 2020; Gholami et al. 2020c). A key step that differs from applications tracing fluvial sediment sources concerns the need to take explicit account of the dominant wind direction to inform source material and target sediment sampling. Another key step in aeolian sediment source fingerprinting is enclosing the study area since a fluvial catchment boundary cannot be used. Here, the study area boundary is based on the wind direction and dominant size fraction in the target sediment sample (e.g. dust, loess or wind-blown sand). The dominant size fraction in dune sand samples is typically $100-300 \mu \mathrm{m}$, and this size fraction typically originates from proximal sources. In the case of finer aeolian sediment (i.e. dust), potential sources include both proximal and regional (distal) sources. Here, investigators can use remote sensing and a HYbrid Single-Particle Lagrangian Integrated Trajectory (HYSPLIT) model to identify distal potential sources for sampling (Gholami et al. 2020c).

\subsection{Informing landscape management through focused integration of sediment fingerprinting}

In the vast majority of cases, sediment fingerprinting is applied as a 'stand-alone' tool, but it is important to acknowledge the benefits of integration with other approaches as a means of advancing either the scientific understanding of landscape scale sediment systems or to provide resource managers with the specific information for targeting interventions for sediment management. Sediment budgets are amongst the 
most common landscape management frameworks for describing the inputs, transport, storage and export of sediment in catchments either qualitatively or quantitatively and integration of sediment fingerprinting data can provide valuable input terms (Walling and Collins 2000; Walling et al. 2001, 2006).

Fingerprinting approaches have been similarly integrated with deterministic models (e.g. SWAT) to describe watershed-level hydrological processes that affect sediment erosion and transport within catchments to inform management strategies and prioritize sub-watershed implementation of best management practices (BMPs) for erosion control by respectively identifying sources of suspended sediment and evaluating the amount of surface runoff generated (Palazón et al. 2014, 2016; Malhotra et al. 2018). These examples highlight that sediment fingerprinting approaches may inform the need to consider additional processes in both qualitative and quantitative models/frameworks as a result of insights gained; they also may assist with deterministic model evaluation, calibration or parameterisation (e.g. Collins and Anthony 2008; Stromqvist et al. 2008). Since many deterministic models are sector or source-specific (e.g. agriculture only), the integration of process-based modelling and source fingerprinting can permit examination of the spatial mismatch often hampering the efficacy of targeting BMPs to a particular source but with an overarching aim of improving water quality at a downstream monitoring station. Here, the source apportionment data can be used to correct the modelled efficacy of the source-specific BMPs (Collins et al. 2014). Recently published spatial strategies for sediment source fingerprinting (Pulley et al. 2017a, b; Blake et al. 2018; Haddadchi et al. 2019) can assist in the integration of such work and process-based modelling since the latter discretizes landscapes into sub-units. Given the controls on the sediment cascade imparted by hillslope-to-channel connectivity, the more spatially refined source tracing procedures better support integration with process models since all source tracing results are scale-dependent (Koiter et al. 2013a, b).

\subsection{Application of sediment fingerprinting to wildfire impacted landscapes}

Sediment fingerprinting approaches are emerging in the characterisation of a broad range of potential impacts and associated risks resulting from climate changeexacerbated landscape disturbances such as wildfires, which can significantly impact ecological and societal goods and services from regional water resources. Wildfires generally reduce infiltration and increase surface runoff (DeBano et al. 1998), thereby promoting erosion and downstream propagation of sediment and associated contaminants. Elevated suspended sediment concentrations are common after wildfire (relative to those observed in unburned watersheds), especially at high flow conditions (Debano et al. 1998; Silins et al. 2009; Smith et al. 2011a); associated nutrients such as phosphorus are thus also frequently elevated (Lane et al. 2008; Emelko et al. 2016). The availability of limiting nutrients such as phosphorus can promote downstream productivity that leads to biofilm development and bed stabilisation in rivers; it ultimately also can result in substantially more erosion of bed sediments in wildfire-impacted watersheds (Stone et al. 2011). Increased nutrient availability can also initiate cascading ecohydrological effects on the abundance and diversity of aquatic organisms at several trophic levels (Silins et al. 2014; Martens et al. 2019) and threaten the uninterrupted provision of safe drinking water (Emelko et al. 2011; Writer et al. 2014).

Investigations integrating sediment fingerprinting and complementary process studies have highlighted both initial and more sustained impacts of wildfire on erosion and sediment delivery processes. To date, such efforts have largely focussed on assessing changes in post-fire sediment sources (e.g. surface versus bank erosion); most of these studies have reported a moderate to strong initial shift from gully and bank sediment sources to surface sources, followed by gradually declining erosion from surface sources, as vegetation begins to recover after wildfire (Blake et al. 2006, 2009; Wilkinson et al. 2009; Smith et al. 2011b, 2012, 2013a). These effects can vary across hydroclimatic regions where post-fire fluvial processes and potential impacts on post-fire bank stability and sources may be important when sufficient precipitation and snowmelt are available to drive erosion and sediment transport (Owens et al. 2006, 2012). Whilst fewer studies have assessed the longevity of fire effects on fine sediments, Stone et al. (2014) used composite geochemical fingerprinting to show that downstream transport of fine sediments from a large fire were still evident 6 to 7 years post-fire. In this case, more than $80 \%$ of the downstream sediment geochemical contribution in a large river basin was generated from $14 \%$ of the upstream landscape affected by a wildfire that occurred 6 to 7 years earlier.

The application of sediment fingerprinting to explore fire effects on both sediment sources and downstream fate of post-fire sediments is promising, but several challenges remain regarding source identification. For example, whilst a range of physical and geochemical properties of sediment have been previously used as tracers in wildfire studies, the results have often been inconclusive because of the differential effects of fire on sediment properties. There remains a critical need to identify and rigorously quantify sediment properties unique to the effects of wildfire on landscapes with different vegetation and source materials to apply these tracers to improve the 
discriminatory power of currently available fingerprinting procedures.

\subsection{Development of open access fingerprinting software to engender robust data processing by the growing user community}

Due to the increasing complexity of sediment source fingerprinting procedures associated with data analysis for confirming source discrimination and un-mixing modelling for source ascription, a few software packages have been produced to facilitate wider uptake of the fingerprinting approach. SIFT (SedIment Fingeprinting Tool; Pulley and Collins 2018) contains the fundamental parts of the decision-tree published by Collins et al. (2017), with key features including the reclassification of a priori source groups using cluster analysis and maps of differences in tracer concentrations and sediment provenance results to provide a visual examination of sediment provenance. Similar to SIFT, The Sediment Source Assessment Tool (Sed_SAT; Gorman-Sanisaca et al. 2017) also contains all of the fundamental parts of a fingerprinting methodology and includes corrections for sediment organic matter content and particle size, tests for outliers and data transformations. Fingerpro (Gaspar et al. 2019) includes a Kruskal-Wallis rank sum test, range test, the option to merge source groups, box plots and bi-plots of source and of sediment tracer concentrations, a linear discriminant analysis and an un-mixing model. Whilst parts of the methodology such as the use of virtual mixtures or multiple composite fingerprints are not included by default, a user can run the model multiple times or input mixture values into the software to achieve these needs.

Despite the dominance of the frequentist approach for unmixing modelling, Bayesian statistical inference is increasingly popular among the international sediment source fingerprinting community (Upadhayay et al. 2017; Davies et al. 2018). Here, for instance, MixSIAR is an inclusive, rich and flexible state-of-the-art Bayesian tracer un-mixing model capable of including fixed and random effects as covariates that explain variability in mixture proportions (Stock et al. 2018). Recently, Upadhayay et al. (2018b) and Blake et al. (2018) used a deconvolutional approach in MixSIAR to deal with tracer variability in sources and the complexities of catchment systems. It should be noted that the Bayesian approach provides a robust basis for combining prior information with data to produce the posterior distributions of source contributions (Upadhayay et al. 2020a, b). These authors used a nonsubjective empirical data-derived informative prior, i.e. a sediment connectivity index, with compound-specific stable isotopic tracers to improve sediment source apportionment at catchment scale. Importantly, however, these models are not always fit-for-purpose; therefore, it is the user responsibility to decide on prior data treatment and the un-mixing modelling framework.

\section{Conclusion}

Global uptake of sediment source fingerprinting continues to accelerate, but there is now a stark concomitant need to standardize key procedural details to ensure greater harmonisation, comparability and high standards. Both the desire to investigate sediment sources in more study catchments and the need to improve our understanding on a number of outstanding challenges, again with a vision of assisting procedural harmonisation, mean that applications are likely to continue to expand. Here, it remains important for the international community to devise and enact a collaborative process to drive harmonisation and standardisation of procedural details. This should include sharing datasets, model code and research facilities and replicating critical experimental work across scales to address the outstanding issues reviewed herein. This paper provides an up-to-date overview of the remaining scientific challenges and emerging trends for sediment fingerprinting and will hopefully assist the convergence of methodological detail to ensure that the approach is still seen as a valuable means of understanding and managing fine-grained sediment problems observed across the world. Our specific recommendations for future critical research topics are:

- To examine for all tracers and across environments and scales therein, the spatial and temporal variability of tracers and the corresponding implications for robust sampling strategies

- To examine for all tracers and across environments and scales therein, conservatism with a view to refining knowledge-based pre-selection

- To examine for all tracers, the physico-chemical basis for source discrimination

- To explore in more depth, stakeholder preferences for the presentation of source fingerprinting results.

Funding Rothamsted Research receives strategic funding from the UK Research and Innovation Biotechnology and Biological Sciences Research Council (UKRI-BBSRC), and the contribution of ALC, MB, TD, PH, SB, HRU and YZ was funded by the Soil to Nutrition institute strategic programme (grant award BBS/E/C/000I0330). The contribution of NMC was supported by the Luxembourg National Research Fund through the CORE programme (PAINLESS project C17/SR/11699372).

\section{Compliance with ethical standards}

Conflict of interest The authors declare that they have no conflicts of interest.

Open Access This article is licensed under a Creative Commons Attribution 4.0 International License, which permits use, sharing, adaptation, distribution and reproduction in any medium or format, as long as 
you give appropriate credit to the original author(s) and the source, provide a link to the Creative Commons licence, and indicate if changes were made. The images or other third party material in this article are included in the article's Creative Commons licence, unless indicated otherwise in a credit line to the material. If material is not included in the article's Creative Commons licence and your intended use is not permitted by statutory regulation or exceeds the permitted use, you will need to obtain permission directly from the copyright holder. To view a copy of this licence, visit http://creativecommons.org/licenses/by/4.0/.

\section{References}

Alewell C, Birkholz A, Meusburger K, Wildhaber YS, Mabit L (2016) Quantitative sediment source attribution with compound-specific isotope analysis in a C3 plant-dominated catchment (central Switzerland). Biogeosciences 13:1587-1596

Appleby PG (2001) Chronostratigraphic techniques in recent sediments. In: Last WM, Smol JP (eds) Tracking environmental change using lake sediments volume 1: basin analysis, coring, and chronological techniques. Kluwer Academic Publishers, Dordrecht, pp 171-203

Appleby PG, Richardson N, Nolan PJ (1991) 241AM dating of lakesediments. Hydrobiologia 214:35-42

Appleby PG, Semertzidou P, Piliposian GT, Chiverrell RC, Schillereff DN, Warburton J (2019) The transport and mass balance of fallout radionuclides in Brotherswater, Cumbria (UK). J Paleolimnol 62: 389-407

Arnaud F, Magand O, Chapron E, Bertrand S, Boes X, Charlet F, Melieres MA (2006) Radionuclide dating (Pb-210, Cs-137, Am241) of recent lake sediments in a highly active geodynamic setting (Lakes Puyehue and Icalma-Chilean Lake District). Sci Total Environ 366:837-850

ATSDR (2015) Agency for toxic substances and disease registry, ATSDR. Web https://www.atsdr.cdc.gov/SPL/. Accessed 05 Nov 2019

Aymerich IF, Oliva M, Giralt S, Martin-Herrero J (2016) Detection of tephra layers in Antarctic sediment cores with hyperspectral imaging. PLoS One 11:e0146578

Baranov V, Lewandowski J, Krause S (2016) Bioturbation enhances the aerobic respiration of lake sediments in warming lakes. Biol Lett 12: 20160448

Batista P, Laceby JP, Silva M, Tassinari D, Bispo D, Curi N, Davies J, Quinton JN (2019) Using pedological knowledge to improve sediment source apportionment in tropical environments. J Soils Sediments 19:3274-3289

Behrooz RD, Gholami H, Telfer MW, Jansen JD, Fathabadi A (2019) Using GLUE to pull apart the provenance of atmospheric dust. Aeolian Res 37:1-13

Beven K, Asadullah A, Bates P, Blyth E, Chappell N, Child S, Cloke H, Dadson S, Everard N, Fowler HJ, Freer J, Hannah DM, Heppell K, Holden J, Lamb R, Lewis H, Morgan G, Parry L, Wagener T (2020) Developing observational methods to drive future hydrological science: can we make a start as a community? Hydrol Process 34:868873

Blaen PJ, Khamis K, Lloyd CEM, Bradley C, Hannah D, Krause S (2016) Real-time monitoring of nutrients and dissolved organic matter in rivers: capturing event dynamics, technological opportunities and future directions. Sci Total Environ 569:647-660

Blake WH, Boeckx P, Stock BC, Smith HG, Bodé S, Upadhayay HR, Gaspar L, Goddard R, Lennard AT, Lizaga I, Lobb DA, Owens PN, Petticrew EL, Kuzyk ZZA, Gari BD, Munishi L, Mtei K, Nebiyu A, Mabit L, Navas A, Semmens BX (2018) A deconvolutional
Bayesian mixing model approach for river basin sediment source apportionment. Sci Rep 8:13073

Blake WH, Ficken KJ, Taylor P, Russell MA, Walling DE (2012) Tracing crop-specific sediment sources in agricultural catchments. Geomorphology 139-140:322-329

Blake WH, Wallbrink PJ, Doerr SH, Shakesby RA, Humphreys GS, English P, Wilkinson S (2006) Using geochemical stratigraphy to indicate post-fire sediment and nutrient fluxes into a water supply reservoir, Sydney, Australia. IAHS Publ 306, IAHS Press, Wallingford, p 363

Blake WH, Wallbrink PJ, Droppo IG (2009) Sediment aggregation and water quality in wildfire-affected river basins. Mar Freshw Res 60: 653-659

Bonniwell EC, Matisoff G, Whiting PJ (1999) Determining the times and distances of particle transit in a mountain stream using fallout radionuclides. Geomorphology 27:75-92

Borrelli P, Robinson DA, Fleischer LR, Lugato E, Ballabio C, Alewell C, Meusburger K, Modugno S, Schutt B, Ferro V, Bagarello V, Van Oost K, Montanarella L, Panagos P (2017) An assessment of the global impact of 21 st century land use change on soil erosion. Nat Commun 8:2013

Brandt C, Benmansour M, Walz L, Nguyen LT, Cadisch G, Rasche F (2018) Integrating compound-specific delta C-13 isotopes and fallout radionuclides to retrace land use type-specific net erosion rates in a small tropical catchment exposed to intense land use change. Geoderma 310:53-64

Brandt C, Cadisch G, Nguyen LT, Vien TD, Rasche F (2016) Compound-specific delta C-13 isotopes and Bayesian inference for erosion estimates under different land use in Vietnam. Geoderma Reg 7:311-322

Bravo-Linares C, Schuller P, Castillo A, Ovando-Fuentealba L, MunozArcos E, Alarcon O, de los Santos-Villalobos S, Cardoso R, Muniz M, dos Anjos RM, Bustamante-Ortega R, Dercon G (2018) First use of a compound-specific stable isotope (CSSI) technique to trace sediment transport in upland forest catchments of Chile. Sci Total Environ 618:1114-1124

Brenner M, Schelske CL, Kenney WF (2004) Inputs of dissolved and particulate $\mathrm{Ra}-226$ to lakes and implications for $\mathrm{Pb}-210$ dating recent sediments. J Paleolimnol 32:53-66

Brosinsky A, Foerster S, Segl K, Kaufmann H (2014) Spectral fingerprinting: sediment source discrimination and contribution modelling of artificial mixtures based on VNIR-SWIR spectral properties. J Soils Sediments 14:1949-1964

Buggle B, Glaser B, Hambach U, Gerasimenko N, Marković S (2011) An evaluation of geochemical weathering indices in loess-paleosol studies. Quat Int 240:12-21

Butz C, Grosjean M, Fischer D, Wunderle S, Tylmann W, Rein B (2015) Hyperspectral imaging spectroscopy: a promising method for the biogeochemical analysis of lake sediments. J Appl Remote Sens 9: 096031

Cade-Menun B, Liu CW (2014) Solution phosphorus-31 nuclear magnetic resonance spectroscopy of soils from 2005 to 2013: a review of sample preparation and experimental parameters. Soil Sci Soc Am J 78:19-37

Carter J, Owens PN, Walling DE, Leeks GJL (2003) Fingerprinting suspended sediment sources in a large urban river system. Sci Total Environ 314-316:513-534

Carter JF, Yates HSA, Tinggi U (2015) Isotopic and elemental composition of roasted coffee as a guide to authenticity and origin. J Agric Food Chem 63:5771-5779

Chang SJ, Blake RE (2015) Precise calibration of equilibrium oxygen isotope fractionations between dissolved phosphate and water from 3 to $37^{\circ} \mathrm{C}$. Geochim Cosmochim Acta 150:314-329

Chao TT (1984) Use of partial dissolution techniques in geochemicalexploration. J Geochem Explor 20:101-135 
Chartin C, Evrard O, Laceby JP, Onda Y, Ottle C, Lefevre I, Cerdan O (2017) The impact of typhoons on sediment connectivity: lessons learnt from contaminated coastal catchments of the Fukushima Prefecture (Japan). Earth Surf Process Landf 42:306-317

Chen S, Zhang W, Zhang JH, Jeppesen E, Liu ZY, Kociolek JP, Xu XY, Wang LQ (2019) Local habitat heterogeneity determines the differences in benthic diatom metacommunities between different urban river types. Sci Total Environ 669:711-720

Clarke RT (2008) A critique of present procedures used to compare performance of rainfall-runoff models. J Hydrol 352:379-387

Collins AL, Anthony SG (2008) Assessing the likelihood of catchments across England and Wales meeting 'good ecological status' due to sediment contributions from agricultural sources. Environ Sci Pol 11:163-170

Collins A, Walling D, Leeks G (1996) Composite fingerprinting of the spatial source of fluvial suspended sediment: a case study of the Exe and Severn River basins, United Kingdom. Géomorphologie 2:4153

Collins AL, Burak E, Harris P, Pulley S, Cardenas L, Tang Q (2019) Field scale temporal and spatial variability of $\delta 13 \mathrm{C}, \delta 15 \mathrm{~N}, \mathrm{TC}$ and $\mathrm{TN}$ soil properties: implications for sediment source tracing. Geoderma 333:108-122

Collins AL, Pulley S, Foster IDL, Gellis A, Porto P, Horowitz AJ (2017) Sediment source fingerprinting as an aid to catchment management: a review of the current state of knowledge and a methodological decision-tree for end-users. J Environ Manag 194:86-108

Collins AL, Stutter M, Kronvang B (2014) Mitigating diffuse pollution from agriculture: international approaches and experience. Sci Total Environ 468-469:1173-1177

Collins AL, Walling DE (2002) Selecting fingerprint properties for discriminating potential suspended sediment sources in river basins. J Hydrol 261:218-244

Collins AL, Walling DE (2004) Documenting catchment suspended sediment sources: problems, approaches and prospects. Prog Phys Geogr 28:159-196

Collins AL, Walling DE, Leeks GJL (1997) Use of the geochemical record preserved in floodplain deposits to reconstruct recent changes in river basin sediment sources. Geomorphology 19:151-167

Collins AL, Walling DE, Leeks GJL (1998) Use of composite fingerprints to determine the provenance of the contemporary suspended sediment load transported by rivers. Earth Surf Process Landf 23: $31-52$

Collins AL, Williams LJ, Zhang YS, Marius M, Dungait JAJ, Smallman DJ, Dixon ER, Stringfellow A, Sear DA, Jones JI, Naden PS (2013) Catchment source contributions to the sediment-bound organic matter degrading salmonid spawning gravels in a lowland river, southern England. Sci Total Environ 456-457:181-195

Collins AL, Zhang YS, Walling DE, Black K (2010) Apportioning sediment sources in a grassland dominated agricultural catchment in the UK using a new tracing framework. In: Banasik K, Horowitz AJ, Owens PN, Stone M, Walling DE (eds) Sediment dynamics for a changing future. IAHS Publication 337, IAHS Press, Wallingford, $p$ 68

Conn KE, Dinicola RS, Black RW, Cox SE, Sheibley RW, Foreman JR, Senter CA, Peterson NT (2016) Continuous-flow centrifugation to collect suspended sediment for chemical analysis. Report No: 23287055, US Geological Survey, Washington, USA

Cooper RJ, Krueger T (2017) An extended Bayesian sediment fingerprinting mixing model for the full Bayes treatment of geochemical uncertainties. Hydrol Process 31:1900-1912

Cooper RJ, Pedentchouk N, Hiscock KM, Disdle P, Krueger T, Rawlins BG (2015) Apportioning sources of organic matter in streambed sediments: an integrated molecular and compound-specific stable isotope approach. Sci Total Environ 520:187-197

Cranwell P (1981) Diagenesis of free and bound lipids in terrestrial detritus deposited in a lacustrine sediment. Org Geochem 3:79-89
Dabrin A, Schäfer J, Bertrand O, Masson M, Blanc G (2014) Origin of suspended matter and sediment inferred from the residual metal fraction: application to the Marennes Oleron Bay, France. Cont Shelf Res 72:119-130

Davies J, Olley J, Hawker D, McBroom J (2018) Application of the Bayesian approach to sediment fingerprinting and source attribution. Hydrol Process 32:3978-3995

DeBano LF, Neary DG, Ffolliott PF (1998) Fire effects on ecosystems. Wiley, Chichester

Desmet M, Mourier B, Mahler BJ, Van Metre PC, Roux G, Persat H, Lefevre I, Peretti A, Chapron E, Simonneau A, Miege C, Babut M (2012) Spatial and temporal trends in PCBs in sediment along the lower Rhone River, France. Sci Total Environ 433:189-197

Dinel H, Schnitzer M, Mehuys G (1990) Soil lipids: origin, nature, content, decomposition, and effect on soil physical properties. In: Bollag JM, Stotzky G (eds) Soil biochemistry. Marcel Dekker Inc, New York, pp 397-429

Dominik J, Burrus D, Vernet JP (1987) Transport of the environmental radionuclides in an alpine watershed. Earth Planet Sci Lett 84:165180

Du PF, Walling DE (2017) Fingerprinting surficial sediment sources: exploring some potential problems associated with the spatial variability of source material properties. J Environ Manag 194:4-15

Dukes D, Gonzales HB, Ravi S, Grandstaff DE, Van Pelt RS, Li J, Wang G, Sankey JB (2018) Quantifying postfire aeolian sediment transport using rare earth element tracers. J Geophys Res Biogeosci 123: 288-299

Duzgoren-Aydin N, Aydin A, Malpas J (2002) Re-assessment of chemical weathering indices: case study on pyroclastic rocks of Hong Kong. Eng Geol 63:99-119

Dwyer J, Mills J, Ingram J, Taylor J, Burton R, Blackstock K, Slee B, Brown K, Schwarz G, Mathews K, Dilley R (2007) Understanding and influencing positive behavioural change in farmers and land managers - a project for Defra. Final Report, Defra, London, UK

Eglinton TI, Eglinton G (2008) Molecular proxies for paleoclimatology. Earth Planet Sci Lett 275:1-16

Emelko MB, Silins U, Bladon KD, Stone M (2011) Implications of land disturbance on drinking water treatability in a changing climate: demonstrating the need for "source water supply and protection" strategies. Water Res 45:461-472

Emelko MB, Stone M, Silins U, Allin D, Collins AL, Williams CHS, Martens AM, Bladon KD (2016) Sediment-phosphorus dynamics can shift aquatic ecology and cause downstream legacy effects after wildfire in large river systems. Glob Chang Biol 22:1168-1184

Eshuis J, Stuiver M (2005) Learning in context through conflict and alignment: farmers and scientists in search of sustainable agriculture. Agric Hum Values 22:137-148

Evrard O, Durand R, Foucher A, Tiecher T, Sellier V, Onda Y, Lefevre I, Cerdan O, Laceby JP (2019a) Using spectrocolourimetry to trace sediment source dynamics in coastal catchments draining the main Fukushima radioactive pollution plume (2011-2017). J Soils Sediments 19:3290-3301

Evrard O, Laceby JP, Ficetola GF, Gielly L, Huon S, Lefevre I, Onda Y, Poulenard J (2019b) Environmental DNA provides information on sediment sources: a study in catchments affected by Fukushima radioactive fallout. Sci Total Environ 665:873-881

Evrard O, Laceby JP, Huon S, Lefèvre I, Sengtaheuanghoung O, Ribolzi $\mathrm{O}$ (2016) Combining multiple fallout radionuclides $(137 \mathrm{Cs}, 7 \mathrm{Be}$, $210 \mathrm{Pbxs}$ ) to investigate temporal sediment source dynamics in tropical, ephemeral riverine systems. J Soils Sediments 16:1130-1144

Evrard O, Nemery J, Gratiot N, Duvert C, Ayrault S, Lefevre I, Poulenard J, Prat C, Bonte P, Esteves M (2010) Sediment dynamics during the rainy season in tropical highland catchments of central Mexico using fallout radionuclides. Geomorphology 124:42-54

Fang J, Wu F, Xiong Y, Li F, Du X, An D, Wang L (2014) Source characterization of sedimentary organic matter using molecular 
and stable carbon isotopic composition of n-alkanes and fatty acids in sediment core from Lake Dianchi, China. Sci Total Environ 473 474:410-421

Feakins SJ, Wu MS, Ponton C, Galy V, West AJ (2018) Dual isotope evidence for sedimentary integration of plant wax biomarkers across an Andes-Amazon elevation transect. Geochimi Cosmochim Acta 242:64-81

Fedo C, Wayne Nesbitt H, Young G (1995) Unraveling the effects of potassium metasomatism in sedimentary rocks and paleosols, with implications for paleoweathering conditions and provenance. Geology 23:921-924

Fifield LK, Morgenstern U (2009) Silicon-32 as a tool for dating the recent past. Quat Geochronol 4:400-405

Filonchyk M, Yan HW, Yang SW, Lu XM (2018) Detection of aerosol pollution sources during sandstorms in northwestern China using remote sensed and model simulated data. Adv Space Res 61: 1035-1046

Finch ZS, Seiner BN, Arrigo LM, Strivens JE, Keillor ME, Hossbach TW, Myers AW, Gill GA (2016) Toward sufficient reduction of radio-impurities for Si-32 sediment age dating. J Radioanal Nucl Chem 307:2451-2458

Fitzpatrick FA, Peppler MC, DePhilip MM, Lee KE (2006) Geomorphic characteristics and classification of Duluth-area streams, Minnesota. Report No, U.S. Geological Survey, USA

Foster ID, Boardman J, Keay-Bright J (2007) Sediment tracing and environmental history for two small catchments, Karoo Uplands, South Africa. Geomorphology 90:126-143

Foster IDL, Biddulph M, Boardman J, Copeland-Phillips R, Evans J, Pulley SJ, Zhang YS, Collins AL (2019) A palaeoenvironmental study of particle size-specific connectivity - new insights and implications from the West Sussex Rother Catchment, United Kingdom. River Res Appl 35:1192-1202

Foster IDL, Charlesworth SM (1996) Heavy metals in the hydrological cycle: trends and explanation. Hydrol Process 10:227-261

Foster IDL, Lees JA (2000) Tracers in geomorphology: theory and applications in tracing fine particulate sediments. In: Foster IDL (ed) Tracers in geomorphology. Wiley, Chichester, pp 3-20

Foster IDL, Lees JA, Owens PN, Walling DE (1998) Mineral magnetic characterization of sediment sources from an analysis of lake and floodplain sediments in the catchments of the Old Mill Reservoir and Slapton Ley, South Devon, UK. Earth Surf Process Landf 23: 685-703

Foster IDL, Mighall TM, Proffitt H, Walling DE, Owens PN (2006) Postdepositional Cs-137 mobility in the sediments of three shallow coastal lagoons, SW England. J Paleolimnol 35:881-895

Foster IDL, Oldfield F, Flower RJ, Keatings K (2008) Mineral magnetic signatures in a long core from Lake Qarun, Middle Egypt. J Paleolimnol 40:835-849

Foucher A, Evrard O, Cerdan O, Chabert C, Lecompte F, Lefevre I, Vandromme R, Salvador-Blanes S (2020) A quick and low-cost technique to identify layers associated with heavy rainfall in sediment archives during the Anthropocene. Sedimentology 67:486501

Fox JF, Papanicolaou AN (2007) The use of carbon and nitrogen isotopes to study watershed erosion processes. J Am Water Resour Assoc 43: 1047-1064

Franks SW, Rowan JS (2000) Multi-parameter fingerprinting of sediment sources: uncertainty estimation and tracer selection: computational methods in water resources. Proceedings of the XIII International Conferenceon Computational Methods in Water Resources, Calgary, June 2000. Balkema, Rotterdam, pp 1067-1074

Froger C, Ayrault S, Evrard O, Monvoisin G, Bordier L, Lefevre I, Quantin C (2018) Tracing the sources of suspended sediment and particle-bound trace metal elements in an urban catchment coupling elemental and isotopic geochemistry, and fallout radionuclides. Environ Sci Pollut Res 25:28667-28681
Froger C, Ayrault S, Gasperi J, Caupos E, Monvoisin G, Evrard O, Quantin C (2019) Innovative combination of tracing methods to differentiate between legacy and contemporary PAH sources in the atmosphere-soil-river continuum in an urban catchment (Orge River, France). Sci Total Environ 669:448-458

Fryirs K, Brierley G (2001) Bega River: Impacts of European settlement on sediment transfer relationships. In: Marutani T, Brierley G, Trustrum N, Page M (eds) Source-to-sink sedimentary cascades in pacific rim geo-systems. Matsumoto Sabo Work Office, Ministry of Land, Infrastructure and Transport, Nagano, Japan, pp 120-131

Fyhn MBW, Thomsen TB, Keulen N, Knudsen C, Rizzi M, BojesenKoefoed J, Olivarius M, Tri TV, Phach PV, Minh NQ, Abatzis I, Nielsen LH (2019) Detrital zircon ages and heavy mineral composition along the Gulf of Tonkin - implication for sand provenance in the Yinggehai-Song Hong and Qiongdongnan basins. Mar Pet Geol 101:162-179

Galoski CE, Martínez AEJ, Schultz GB, dos Santos I, Froehner S (2019) Use of n-alkanes to trace erosion and main sources of sediments in a watershed in southern Brazil. Sci Total Environ 682:447-456

Galuszka A, Migaszewski ZM, Namiesnik J (2015) Moving your laboratories to the field - advantages and limitations of the use of field portable instruments in environmental sample analysis. Environ Res 140:593-603

Gamerith V, Steger B, Hochedlinger M, Gruber G (2011) Assessment of UV/VIS-spectrometry performance in combined sewer monitoring under wet weather conditions, 12th International Conference on Urban Drainage, Porto Alegre/ Brazil, 10-15 September

Gao L, Hou JZ, Toney J, MacDonald D, Huang Y (2011) Mathematical modeling of the aquatic macrophyte inputs of mid-chain n-alkyl lipids to lake sediments: Implications for interpreting compound specific hydrogen isotopic records. Geochim Cosmochim Acta 75: 3781-3791

Garcia-Ruiz JM, Begueria S, Lana-Renault N, Nadal-Romero E, Cerda A (2017) Ongoing and emerging questions in water erosion studies. Land Degrad Dev 28:5-21

Garzanti E (2016) From static to dynamic provenance analysissedimentary petrology upgraded. Sediment Geol 336:3-13

Garzanti E, Limonta M, Resentini A, Bandopadhyay PC, Najman Y, Andò S, Vezzoli G (2013) Sediment recycling at convergent plate margins (Indo-Burman Ranges and Andaman-Nicobar Ridge). Earth-Sci Rev 123:113-132

Garzanti E, Wang J-G, Vezzoli G, Limonta M (2016) Tracing provenance and sediment fluxes in the Irrawaddy River basin (Myanmar). Chem Geol 440:73-90

Gaspar L, Blake WH, Smith HG, Lizaga I, Navas A (2019) Testing the sensitivity of a multivariate mixing model using geochemical fingerprints with artificial mixtures. Geoderma 337:498-510

Gellis A, Walling D (2011) Sediment source fingerprinting (tracing) and sediment budgets as tools in targeting river and watershed restoration programs. In: Simon A, Bennett S, Castro J (eds) Stream restoration in dynamic fluvial systems: scientific approaches, analyses, and tools, vol 194. American Geophysical Union Monograph Series, pp 263-291

Gellis AC, Fitzpatrick FA, Schubauer-Berigan J (2016) A manual to identify sources of fluvial sediment. Report no: EPA/600/R-16/ 210. US Environmental Protection Agency, Washington, DC, p 106

Gellis AC, Fuller CC, Van Metre PC (2017) Sources and ages of finegrained sediment to streams using fallout radionuclides in the Midwestern United States. J Environ Manag 194:73-85

Gellis AC, Fuller CC, Van Metre P, Filstrup CT, Tomer MD, Cole KJ, Sabitov TY (2019) Combining sediment fingerprinting with agedating sediment using fallout radionuclides for an agricultural stream, Walnut Creek, Iowa, USA. J Soils Sed 19:3374-3396

Gellis AC, Sanisaca LG (2018) Sediment fingerprinting to delineate sources of sediment in the agricultural and forested Smith Creek 
Watershed, Virginia, USA. J Am Water Resour Assoc 54:11971221

Gellis AC, Noe GB, Clune JW, Myers MK, Hupp CR, Schenk ER, Schwarz GE (2015) Sources of fine-grained sediment in the Linganore Creek watershed, Frederick and Carroll Counties, Maryland, 2008-10: U.S. Geological Survey Scientific Investigations Report 56:2014-5147

Gerke J (2015) The acquisition of phosphate by higher plants: effect of carboxylate release by the roots. A critical review. J Plant Nutr Soil Sci 178:351-364

Gholami H, Kordestani MD, Li JR, Telfer MW, Fathabadi A (2019a) Diverse sources of aeolian sediment revealed in an arid landscape in southeastern Iran using a modified Bayesian un-mixing model. Aeolian Res 41:100547

Gholami H, Middleton N, NazariSamani AA, Wasson R (2017a) Determining contribution of sand dune potential sources using radionuclides, trace and major elements in central Iran. Arab J Geosci $10: 163$

Gholami H, Mohamadifar A, Collins AL (2020a) Spatial mapping of the provenance of storm dust: application of data mining and ensemble modelling. Atmos Res 233:104716

Gholami H, Mohamadifar A, Sorooshian A, Jansen JD (2020b) Machinelearning algorithms for predicting land susceptibility to dust emissions: the case of the Jazmurian Basin, Iran. Atmos Pollut Res 11: 1303-1315

Gholami H, Rahimi S, Fathabadi A, Habibi S, Collins AL (2020c) Mapping the spatial sources of atmospheric dust using GLUE and Monte Carlo simulation. Sci Total Environ 723:138090

Gholami H, TakhtiNajad EJ, Collins AL, Fathabadi A (2019b) Monte Carlo fingerprinting of the terrestrial sources of different particle size fractions of coastal sediment deposits using geochemical tracers: some lessons for the user community. Environ Sci Pollut Res 26: 13560-13579

Gholami H, Telfer MW, Blake WH, Fathabadi A (2017b) Aeolian sediment fingerprinting using a Bayesian mixing model. Earth Surf Process Landf 42:2365-2376

Gibbs MM (2008) Identifying source soils in contemporary estuarine sediments: a new compound-specific isotope method. Estuar Coasts 31:344-359

Gibbs RJ (1970) Mechanisms controlling world water chemistry. Science 170:1088-1090

Gieswein A, Hering D, Lorenz AW (2019) Development and validation of a macroinvertebrate-based biomonitoring tool to assess fine sediment impact in small mountain streams. Sci Total Environ 652: 1290-1301

Giguet-Covex C, Ficetola GF, Walsh K, Poulenard J, Bajard M, Fouinat L, Sabatier P, Gielly L, Messager E, Develle AL, David F, Taberlet P, Brisset E, Guiter F, Sinet R, Arnaud F (2019) New insights on lake sediment DNA from the catchment: importance of taphonomic and analytical issues on the record quality. Sci Rep 9:14676

Gingele F, De Deckker P (2005) Clay mineral, geochemical and Sr-Nd isotopic fingerprinting of sediments in the Murray-Darling fluvial system, southeast Australia. Aust J Earth Sci 52:965-974

Goldberg K, Humayun M (2010) The applicability of the Chemical Index of Alteration as a paleoclimatic indicator: an example from the Permian of the Paraná Basin, Brazil. Palaeogeogr Palaeoclimatol Palaeoecol 293:175-183

Goossens D (ed) (2003) The on-site and off-site effects of wind erosion. Wind erosion on agricultural land in Europe. European Commission, Luxembourg, pp 29-38

Gorman-Sanisaca LE, Gellis A, Lorenz DL (2017) The sediment source assessment tool (Sed_SAT). United States Geological Survey, Catonsville. https://doi.org/10.5066/f76q1vbx

Graf WL (1996) Transport and deposition of plutonium-contaminated sediments by fluvial processes, Los Alamos Canyon, New Mexico. Geol Soc Am Bull 108:1342-1355
Granger SJ, Heaton THE, Pfahler V, Blackwell MSA, Yuan HM, Collins AL (2017) The oxygen isotopic composition of phosphate in river water and its potential sources in the Upper River Taw catchment, UK. Sci Total Environ 574:680-690

Gross A, Goren T, Pio C, Cardoso J, Tirosh O, Todd MC, Rosenfeld D, Weiner T, Custodio D, Angert A (2015) Variability in sources and concentrations of Saharan dust phosphorus over the Atlantic Ocean. Environ Sci Technol Lett 2:31-37

Gross A, Nishri A, Angert A (2013) Use of phosphate oxygen isotopes for identifying atmospheric P sources: a case study at Lake Kinneret. Environ Sci Technol 47:2721-2727

Gross A, Turner BL, Goren T, Berry A, Angert A (2016) Tracing the sources of atmospheric phosphorus deposition to a tropical rain forest in Panama using stable oxygen isotopes. Environ Sci Technol 50:1147-1156

Guan P, Ng C, Sun M, Tang W (2001) Weathering indices for rhyolitic tuff and granite in Hong Kong. Eng Geol 59:147-159

Guo Y, Yang S, Li C, Bi L, Zhao Y (2017) Sediment recycling and indication of weathering proxies. Acta Geochim 36:498-501

Guo Y, Yang S, Su N, Li C, Yin P, Wang Z (2018) Revisiting the effects of hydrodynamic sorting and sedimentary recycling on chemical weathering indices. Geochim Cosmochim Acta 227:48-63

Haddadchi A, Hicks M, Olley JM, Singh S, Srinivasan MS (2019) Gridbased sediment tracing approach to determine sediment sources. Land Degrad Dev. https://doi.org/10.1002/ldr.3407

Haddadchi A, Ryder DS, Evrard O, Olley J (2013) Sediment fingerprinting in fluvial systems: review of tracers, sediment sources and mixing models. Int J Sediment Res 28:560-578

Haddadchi A, Olley J, Laceby P (2014) Accuracy of mixing models in predicting sediment source contributions. Sci Total Environ 497: $139-152$

Hall G, Pelchat P (1999) Comparability of results obtained by the use of different selective extraction schemer for the determination of element forms in soils. Water Air Soil Pollut 112:41-53

Hancock GJ, Revill AT (2013) Erosion source discrimination in a rural Australian catchment using compound-specific isotope analysis (CSIA). Hydrol Process 27:923-932

Hancock GJ, Wilkinson SN, Hawdon AA, Keen RJ (2014) Use of fallout tracers ${ }^{7} \mathrm{Be},{ }^{210} \mathrm{~Pb}$ and ${ }^{137} \mathrm{Cs}$ to distinguish the form of sub-surface soil erosion delivering sediment to rivers in large catchments. Hydrol Process 28:3855-3874

Harnois L (1988) The CIW index: a new chemical index of weathering. Sediment Geol 55:319-322

Harnois L, Moore JM (1988) Geochemistry and origin of the Ore Chimney Formation, a transported paleoregolith in the Grenville Province of southeastern Ontario, Canada. Chem Geol 69:267-289

Hassan NM, Chang BU, Tokonami S (2017) Comparison of natural radioactivity of commonly used fertilizer materials in Egypt and Japan. J Chemother 9182768

Hatfield RG, Maher BA (2008) Suspended sediment characterization and tracing using a magnetic fingerprinting technique: Bassenthwaite Lake, Cumbria, UK. Holocene 18:105-115

Hoffmann T (2015) Sediment residence time and connectivity in nonequilibrium and transient geomorphic systems. Earth-Sci Rev 150: 609-627

Hopkins JB, Ferguson JM (2012) Estimating the diets of animals using stable isotopes and a comprehensive Bayesian mixing model. PLoS One 7:e28478

Horowitz AJ (1991) Primer on sediment-trace element chemistry. Lewis Publishers, Boca Raton

Horowitz AJ (2013) A review of selected inorganic surface water qualitymonitoring practices: are we really measuring what we think, and if so, are we doing it right? Environ Sci Technol 47:2471-2486

Horowitz AJ, Clarke RT, Merten GH (2015) The effects of sample scheduling and sample numbers on estimates of the annual fluxes of suspended sediment in fluvial systems. Hydrol Process 29:531-543 
Horowitz AJ, Elrick KA, Robbins JA, Cook RB (1995) Effect of mining and related activities on the sediment trace element geochemistry of Lake Coeur d'Alene, Idaho, USA part II: subsurface sediments. Hydrol Process 9:35-54

Horowitz AJ, Stephens VC (2008) The effects of land use on fluvial sediment chemistry for the conterminous US - results from the first cycle of the NAWQA Program: trace and major elements, phosphorus, carbon, and sulfur. Sci Total Environ 400:290-314

Hua Q (2009) Radiocarbon: a chronological tool for the recent past. Quat Geochronol 4:378-390

Huon S, de Rouw A, Bonté P, Robain H, Valentin C, Lefèvre I, Girardin C, Le Troquer Y, Podwojewski P, Sengtaheuanghoung O (2013) Long-term soil carbon loss and accumulation in a catchment following the conversion of forest to arable land in northern Laos. Agric Ecosyst Environ 169:43-57

Hutchinson SM (1995) Use of magnetic and radiometric measurements to investigate erosion and sedimentation in a British upland catchment. Earth Surf Process Landf 20:293-314

Irfan T (1996) Mineralogy, fabric properties and classification of weathered granites in Hong Kong. Quart J Eng Geol Hydrogeol 29:5-35

Jackson A. (2016) SIBER. Web https://github.com/AndrewLJackson/ SIBER. Accessed 19 Nov 2019

Jacq K, Perrette Y, Fanget B, Sabatier P, Coquin D, Martinez-Lamas R, Debret M, Arnaud F (2019) High-resolution prediction of organic matter concentration with hyperspectral imaging on a sediment core. Sci Total Environ 663:236-244

Jayawardena US, Izawa E (1994) Application of present indices of chemical weathering for Precambrian metamorphic rocks in Sri Lanka. Bull Int Assoc Eng Geol 49:55-61

Jones J, Collins A, Naden P, Sear D (2012) The relationship between fine sediment and macrophytes in rivers. River Res Appl 28:1006-1018

Jones R, Chambers FM, Bensonevans K (1991) Heavy-metals (Cu and $\mathrm{Zn}$ ) in recent sediments of Llangorse Lake, Wales - nonferrous smelting, napoleon and the price of wheat - a paleoecological study. Hydrobiologia 214:149-154

Karwan DL, Pizzuto JE, Aalto R, Marquard J, Harpold A, Skalak K, Benthem A, Levia DF, Siegert CM, Aufdenkampe AK (2018) Direct channel precipitation and storm characteristics influence short-term fallout radionuclide assessment of sediment source. Water Resour Res 54:4579-4594

Kemp P, Sear D, Collins A, Naden P, Jones I (2011) The impacts of fine sediment on riverine fish. Hydrol Process 25:1800-1821

Kim D, Kumfer BM, Anastasio C, Kennedy IM, Young TM (2009) Environmental aging of polycyclic aromatic hydrocarbons on soot and its effect on source identification. Chemosphere 76:1075-1081

Klages M, Hsieh Y (1975) Suspended solids carried by the Gallatin River of Southwestern Montana: II. Using mineralogy for inferring sources. J Environ Qual 4:68-73

Koiter AJ, Owens PN, Petticrew EL, Lobb DA (2013a) The behavioural characteristics of sediment properties and their implications for sediment fingerprinting as an approach for identifying sediment sources in river basins. Earth Sci Rev 125:24-42

Koiter AJ, Lobb DA, Owens PN, Petticrew EL, Tiessen KD, Li S (2013b) Investigating the role of connectivity and scale in assessing the sources of sediment in an agricultural watershed in the Canadian prairies using sediment source fingerprinting. J Soils Sediments 13:1676-1691

Kraushaar S, Schumann T, Ollesch G, Schubert M, Vogel H-J, Siebert C (2015) Sediment fingerprinting in northern Jordan: element-specific correction factors in a carbonatic setting. J Soils Sediments 15: 2155-2173

Krishnappan BG, Chambers PA, Benoy G, Culp J (2009) Sediment source identification: a review and a case study in some Canadian streams. Can J Civ Eng 36:1622-1633

Laceby JP, Evrard O, Smith HG, Blake WH, Olley JM, Minella JPG, Owens PN (2017) The challenges and opportunities of addressing particle size effects in sediment source fingerprinting: a review. Earth-Sci Rev 169:85-103

Laceby JP, Gellis AC, Koiter AJ, Blake WH, Evrard O (2019) Prefaceevaluating the response of critical zone processes to human impacts with sediment source fingerprinting. J Soils Sediments 19:32453254

Laceby JP, Huon S, Onda Y, Vaury V, Evrard O (2016) Do forests represent a long-term source of contaminated particulate matter in the Fukushima Prefecture? J Environ Manag 183:742-753

Laceby JP, McMahon J, Evrard O, Olley J (2015) A comparison of geological and statistical approaches to element selection for sediment fingerprinting. J Soils Sediments 15:2117-2131

Lake N, Martínez-Carreras N, Shaw P, Collins AL (2019) Testing the ability of submersible spectrophotometers to trace suspended sediment sources at high-temporal frequency. In: Global change, landscape ageing and the pulse of catchments. EGU Leonardo Conference Series on Earth's Hydrological Cycle, Esch sur Alzette, Luxembourg

Lamba J, Karthikeyan KG, Thompson AM (2015) Using radiometric fingerprinting and phosphorus to elucidate sediment transport dynamics in an agricultural watershed. Hydrol Process 29:2681-2693

Lancaster ST, Casebeer NE (2007) Sediment storage and evacuation in headwater valleys at the transition between debris-flow and fluvial processes. Geology 35:1027-1030

Lane PNJ, Sheridan GJ, Noske PJ, Sherwin CB (2008) Phosphorus and nitrogen exports from SE Australian forests following wildfire. J Hydrol 361:186-198

Lark RM (2012) Towards soil geostatistics. Spat Stat 1:92-99

Lauber CL, Ramirez KS, Aanderud Z, Lennon J, Fierer N (2013) Temporal variability in soil microbial communities across land-use types. ISME J 7:1641-1650

Lauer N, Vengosh A (2016) Age dating oil and gas wastewater spills using radium isotopes and their decay products in impacted soil and sediment. Environ Sci Technol Lett 3:205-209

Le Cloarec MF, Bonte P, Lefevre I, Mouchel JM, Colbert S (2007) Distribution of ${ }^{7} \mathrm{Be},{ }^{210} \mathrm{~Pb}$ and ${ }^{137} \mathrm{Cs}$ in watersheds of different scales in the Seine River basin: inventories and residence times. Sci Total Environ 375:125-139

Le Gall M, Ayrault S, Evrard O, Laceby JP, Gateuille D, Lefèvre I, Mouchel J-M, Meybeck M (2018) Investigating the metal contamination of sediment transported by the 2016 Seine River flood (Paris, France). Environ Pollut 240:125-139

Le Gall M, Evrard O, Foucher A, Laceby JP, Salvador-Blanes S, Maniere L, Lefevre I, Cerdan O, Ayrault S (2017a) Investigating the temporal dynamics of suspended sediment during flood events with 7Be and $210 \mathrm{Pbxs}$ measurements in a drained lowland catchment. Sci Rep 7: 42099

Le Gall M, Evrard O, Thil F, Foucher A, Laceby JP, Manière L, SalvadorBlanes S, Ayrault S (2017b) Examining suspended sediment sources and dynamics during flood events in a drained catchment using radiogenic strontium isotope ratios $(87 \mathrm{Sr} / 86 \mathrm{Sr})$. Chem Geol 449:147-157

Lee A-S, Huang J-JS, Burr G, Kao LC, Wei K-Y, Liou SYH (2018) High resolution record of heavy metals from estuary sediments of Nankan River (Taiwan) assessed by rigorous multivariate statistical analysis. Quat Int 527:44-51

Lees J (1999) Evaluating magnetic parameters for use in source identification, classification and modelling of natural and environmental materials. In: Walden J, Oldfield F, Smith J (eds) Environmental magnetism: a practical guide. QRA Technical Guide 6, Quaternary Research Association, London, pp 113-138

Li A, Jang JK, Scheff PA (2003) Application of EPA CMB8.2 model for source apportionment of sediment PAHs in Lake Calumet, Chicago. Environ Sci Technol 37:2958-2965 
Li C, Yang S (2010) Is chemical index of alteration (CIA) a reliable proxy for chemical weathering in global drainage basins? Am J Sci 310: $111-127$

Liu B, Niu Q, Qu J, Zu R (2016) Quantifying the provenance of aeolian sediments using multiple composite fingerprints. Aeolian Res 22: $117-122$

Lizaga I, Gaspar L, Blake WH, Latorre B, Navas A (2019) Fingerprinting changes of source apportionments from mixed land uses in stream sediments before and after an exceptional rainstorm event. Geomorphology 341:216-229

Lopez-Roldan R, Platikanov S, Martin-Alonso J, Tauler R, Gonzalez S, Cortina JL (2016) Integration of ultraviolet-visible spectral and physicochemical data in chemometrics analysis for improved discrimination of water sources and blends for application to the complex drinking water distribution network of Barcelona. J Clean Prod 112:4789-4798

Lowe DJ (2011) Tephrochronology and its application: a review. Quat Geochronol 6:107-153

Mabit L, Benmansour M, Walling DE (2008) Comparative advantages and limitations of the fallout radionuclides ${ }^{137} \mathrm{Cs},{ }^{210} \mathrm{Pbex}$ and ${ }^{7} \mathrm{Be}$ for assessing soil erosion and sedimentation. J Environ Radioact 99: 1799-1807

Mabit L, Bernard C, Lee Zhi Yi A, Fulajtar E, Dercon G, Zaman M, Toloza A, Heng L (2018a) Promoting the use of isotopic techniques to combat soil erosion: an overview of the key role played by the SWMCN Subprogramme of the Joint FAO/IAEA Division over the last 20 years. Land Degrad Dev 29:3077-3091

Mabit L, Gibbs M, Mbaye M, Meusburger K, Toloza A, Resch C, Klik A, Swales A, Alewell C (2018b) Novel application of Compound Specific Stable Isotope (CSSI) techniques to investigate on-site sediment origins across arable fields. Geoderma 316:19-26

Macklin MG, Hudson-Edwards KA, Dawson EJ (1997) The significance of pollution from historic metal mining in the Pennine orefields on river sediment contaminant fluxes to the North Sea. Sci Total Environ 194-195:391-397

Maetens W, Vanmaercke M, Poesen J, Jankauskas B, Jankauskiene G, Ionita I (2012) Effects of land use on annual runoff and soil loss in Europe and the Mediterranean: a meta-analysis of plot data. Progr Phys Geog 36:599-653

Maina CW, Sang JK, Raude JM, Mutua BM (2019) Geochronological and spatial distribution of heavy metal contamination in sediment from Lake Naivasha, Kenya. J Radiat Res Appl Sci 12:37-54

Malhotra K, Lamba J, Srivastava P, Shepherd S (2018) Fingerprinting suspended sediment sources in an urbanized watershed. Water 10: 1573

Mariotti A, Peterschmitt E (1994) Forest savanna ecotone dynamics in India as revealed by carbon-isotope ratios of soil organic-matter. Oecologia 97:475-480

Martens AM, Silins U, Proctor HC, Williams CHS, Wagner MJ, Emelko MB, Stone M (2019) Long-term impact of severe wildfire and postwildfire salvage logging on macroinvertebrate assemblage structure in Alberta's Rocky Mountains. Int J Wildland Fire 28:738-749

Martinez-Carreras N, Schwab MP, Klaus J, Hissler C (2016) In situ and high frequency monitoring of suspended sediment properties using a spectrophotometric sensor. Hydrol Process 30:3533-3540

Matheron G (2012) Estimating and choosing: an essay on probability in practice. Springer Science \& Business Media, Springer, Berlin

Matisoff G, Wilson CG, Whiting PJ (2005) The ${ }^{7} \mathrm{Be} /{ }^{210} \mathrm{Pbxs}$ ratio as an indicator of suspended sediment age or fraction new sediment in suspension. Earth Surf Process Landf 30:1191-1201

Matsumoto K, Kawamura K, Uchida M, Shibata Y (2007) Radiocarbon content and stable carbon isotopic ratios of individual fatty acids in subsurface soil: implication for selective microbial degradation and modification of soil organic matter. Geochem J 41:483-492
Matys Grygar T, Popelka J (2016) Revisiting geochemical methods of distinguishing natural concentrations and pollution by risk elements in fluvial sediments. J Geochem Explor 170:39-57

McAlister JJ, Smith BJ, Curran JA (2003) The use of sequential extraction to examine iron and trace metal mobilisation and the casehardening of building sandstone: a preliminary investigation. Microchem J 74:5-18

McBratney AB, Santos MLM, Minasny B (2003) On digital soil mapping. Geoderma 117:3-52

McGeehin J, Burr GS, Hodgins G, Bennett SJ, Robbins JA, Morehead N, Markewich H (2004) Stepped-combustion C-14 dating of bomb carbon in lake sediment. Radiocarbon 46:893-900

Mclaren TI, Verel R, Frossard E (2019) The structural composition of soil phosphomonoesters as determined by solution P-31 NMR spectroscopy and transverse relaxation (T-2) experiments. Geoderma 345: 31-37

McLennan SM (1993) Weathering and global denudation. J Geol 101: 295-303

Meybeck M (1987) Global chemical weathering of surficial rocks estimated from river dissolved loads. Am J Sci 287:401-428

Meybeck M, Helmer R (1989) The quality of rivers: from pristine stage to global pollution. Glob Planet Chang 75:283-309

Miller JR, Mackin G, Miller SMO (2015) Application of geochemical tracers to fluvial sediment. Springer, Berlin

Miller JR, Orbock-Miller SM (2007) Contaminated rivers: a geomorphological-geochemical approach to site assessment and remediation. Springer International Publishing, Dordrecht $418 \mathrm{p}$

Minasny B, McBratney AB (2016) Digital soil mapping: a brief history and some lessons. Geoderma 264:301-311

Mohammadi Raigani Z, Nosrati K, Collins AL (2019) Fingerprinting sub-basin spatial sediment sources in a large Iranian catchment under dry-land cultivation and rangeland farming: combining geochemical tracers and weathering indices. J Hydrol: Reg Stud 24: 100613

Moignien R (1966) Review of research on laterites. Natural Resources Research IV. United Nations Educational Scientific and Cultural Organization (UNESCO), Vaillant-Carmanne, Liège 148 pp

Mol L (2014) Investigations into the relationship between changes in internal moisture regimes and rock surface deterioration in cavernous sandstone features. Earth Surf Process Landf 39:914-927

Mol L, Viles HA (2012) The role of rock surface hardness and internal moisture in tafoni development in sandstone. Earth Surf Process Landf 37:301-314

Montanarella L (2015) Agricultural policy: govern our soils. Nature 528: $32-33$

Montgomery DR (2007) Soil erosion and agricultural sustainability. Proc Natl Acad Sci USA 104:13268-13272

Motha JA, Wallbrink PJ, Hairsine PB, Grayson RB (2002) Tracer properties of eroded sediment and source material. Hydrol Process 16: 1983-2000

Motha J, Wallbrink P, Hairsine P, Grayson R (2003) Determining the sources of suspended sediment in a forested catchment in southeastern Australia. Water Resour Res 39:1056

Mourier B, Desmet M, Van Metre PC, Mahler BJ, Perrodin Y, Roux G, Bedell JP, Lefevre I, Babut M (2014) Historical records, sources, and spatial trends of PCBs along the Rhone River (France). Sci Total Environ 476:568-576

Mukundan R, Radcliffe DE, Ritchie JC, Risse LM, Mckinley RA (2010) Sediment fingerprinting to determine the source of suspended sediment in a southern piedmont stream. J Environ Qual 39:1328-1337

Mukundan R, Walling DE, Gellis AC, Slattery MC, Radcliffe DE (2012) Sediment source fingerprinting: transforming from a research tool to a management tool. J Am Water Resour Assoc 48:1241-1257

Nadlonek W, Bojakowska I (2018) Variability of chemical weathering indices in modern sediments of the Vistula and Odra Rivers, (Poland). Appl Ecol Environ Res 16:2453-2473 
Navratil O, Evrard O, Esteves M, Legout C, Ayrault S, Nemery J, MateMarin A, Ahmadi M, Lefevre I, Poirel A, Bonte P (2012) Temporal variability of suspended sediment sources in an alpine catchment combining river/rainfall monitoring and sediment fingerprinting. Earth Surf Process Landf 37:828-846

Négrel P, Sadeghi M, Ladenberger A, Reimann C, Birke M (2015) Geochemical fingerprinting and source discrimination of agricultural soils at continental scale. Chem Geol 396:1-15

Nesbitt HW, Young GM (1982) Early Proterozoic climates and plate motions inferred from major element chemistry of lutites. Nature 299:715-717

Ng C, Guan P, Shang Y (2001) Weathering mechanisms and indices of the igneous rocks of Hong Kong. Q J Eng Geol Hydrogeol 34:133151

Niu B, Tan L, Zhang XJ, Qu J, An Z, Wang J, Liu B, Wang T, Li K (2020) Targeted control of sand hazards for a railway in extremely arid regions using fingerprinting approaches. Geomorphology 361 : 107189

Noij THM, Bobeldijk I (2003) Novel monitoring concepts to acquire new water quality knowledge. Water Sci Technol 47:181-188

Nosrati K, Fathi Z, Collins AL (2019) Fingerprinting sub-basin spatial suspended sediment sources by combining geochemical tracers and weathering indices. Environ Sci Pollut Res 26:28401-28414

Nosrati K, Haddadchi A, Collins AL, Jalali S, Zare MR (2018) Tracing sediment sources in a mountainous forest catchment under road construction in northern Iran: comparison of Bayesian and frequentist approaches. Environ Sci Pollut Res 25:30979-30997

Ohta T, Arai H (2007) Statistical empirical index of chemical weathering in igneous rocks: a new tool for evaluating the degree of weathering. Chem Geol 240:280-297

Oldfield F, Wu RJ (2000) The magnetic properties of the recent sediments of Brothers Water, NW England. J Paleolimnol 23:165-174

Oliva P, Viers J, Dupré B (2003) Chemical weathering in granitic environments. Chem Geol 202:225-256

Olley J, Burton J, Smolders K, Pantus F, Pietsch T (2013) The application of fallout radionuclides to determine the dominant erosion process in water supply catchments of subtropical South-east Queensland, Australia. Hydrol Process 27:885-895

Olley JM, Murray AS, Mackenzie DH, Edwards K (1993) Identifying sediment sources in a gullied catchment using natural and anthropogenic radioactivity. Water Resour Res 29:1037-1043

Owens PN, Batalla RJ, Collins AJ, Gomez B, Hicks DM, Horowitz AJ, Kondolf GM, Marden M, Page MJ, Peacock DH, Petticrew EL, Salomons W, Trustrum NA (2005) Fine-grained sediment in river systems: environmental significance and management issues. River Res Appl 21:693-717

Owens PN, Blake WH, Giles TR, Williams ND (2012) Determining the effects of wildfire on sediment sources using ${ }^{137} \mathrm{Cs}$ and unsupported ${ }^{210} \mathrm{~Pb}$ : the role of landscape disturbances and driving forces. J Soils Sediments 12:982-994

Owens PN, Blake WH, Gaspar L, Gateuille D, Koiter AJ, Lobb DA, Petticrew EL, Reiffarth DG, Smith HG, Woodward JC (2016) Fingerprinting and tracing the sources of soils and sediments: Earth and ocean science, geoarchaeological, forensic, and human health applications. Earth-Sci Rev 162:1-23

Owens PN, Blake WH, Petticrew EL (2006) Changes in sediment sources following wildfire in mountainous terrain: a paired-catchment approach, British Columbia, Canada. In: Kronvang B, Faganeli J, Ogrinc N (eds) The interactions between sediments and water. Springer, Dordrecht, pp 273-281

Parker A (1970) An index of weathering for silicate rocks. Geol Mag 107: 501-504

Palazón L, Gaspar L, Latorre B, Blake WH, Navas A (2014) Evaluating the importance of surface soil contributions to reservoir sediment in alpine environments: a combined modelling and fingerprinting approach in the Posets-Maladeta Natural Park. Solid Earth 5:963-978
Palazón L, Latorre B, Gaspar L, Blake WH, Smith HG, Navas A (2015) Comparing catchment sediment fingerprinting procedures using an autoevaluation approach with virtual sample mixtures. Sci Total Environ 532:456-466

Palazón L, Latorre B, Gaspar L, Blake WH, Smith HG, Navas A (2016) Combining catchment modelling and sediment fingerprinting to assess sediment dynamics in a Spanish Pyrenean river system. Sci Total Environ 569:1136-1148

Parsons AJ, Foster IDL (2011) What can we learn about soil erosion from the use of Cs-137? Earth-Sci Rev 108:101-113

Phillips JM, Russell MA, Walling DE (2000) Time-integrated sampling of fluvial suspended sediment: a simple methodology for small catchments. Hydrol Process 14:2589-2602

Pickup G, Marks A (2000) Identifying large-scale erosion and deposition processes from airborne gamma radiometrics and digital elevation models in a weathered landscape. Earth Surf Process Landf 25:535557

Pimentel D (2006) Soil erosion: a food and environmental threat. Environ Dev Sustain 8:119-137

Pistocchi C, Tamburini F, Gruau G, Ferhi A, Trevisan D, Doriaz JM (2017) Tracing the sources and cycling of phosphorus in river sediments using oxygen isotopes: methodological adaptations and first results from a case study in France. Water Res 111:346-356

Pittam NJ, Foster IDL, Mighall TM (2009) An integrated lake-catchment approach for determining sediment source changes at Aqualate Mere, Central England. J Paleolimnol 42:215-232

Pizzuto J, Schenk ER, Hupp CR, Gellis A, Noe G, Williamson E, Karwan DL, O'Neal M, Marquard J, Aalto R, Newbold D (2014) Characteristic length scales and time-averaged transport velocities of suspended sediment in the mid-Atlantic Region, USA. Water Resour Res 50:790-805

Pola A, Crosta GB, Fusi N, Castellanza R (2014) General characterization of the mechanical behaviour of different volcanic rocks with respect to alteration. Eng Geol 169:1-13

Poulenard J, Perrette Y, Fanget B, Quetin P, Trevisan D, Dorioz JM (2009) Infrared spectroscopy tracing of sediment sources in a small rural watershed (French Alps). Sci Total Environ 407:2808-2819

Price JR, Velbel MA (2003) Chemical weathering indices applied to weathering profiles developed on heterogeneous felsic metamorphic parent rocks. Chem Geol 202:397-416

Pulley S, Collins AL (2018) Tracing catchment fine sediment sources using the new SIFT (SedIment Fingerprinting Tool) open source software. Sci Total Environ 635:838-858

Pulley S, Foster I, Antunes P (2015a) The uncertainties associated with sediment fingerprinting suspended and recently deposited fluvial sediment in the Nene river basin. Geomorphology 228:303-319

Pulley S, Foster I, Collins AL (2017a) The impact of catchment source group classification on the accuracy of sediment fingerprinting outputs. J Environ Manag 194:16-26

Pulley S, Rowntree K (2016) The use of an ordinary colour scanner to fingerprint sediment sources in the South African Karoo. J Environ Manag 165:253-262

Pulley S, Rowntree K, Foster I (2015b) Conservatism of mineral magnetic signatures in farm dam sediments in the South African Karoo: the potential effects of particle size and post-depositional diagenesis. J Soils Sediments 15:2387-2397

Pulley S, Van Der Waal B, Collins AL, Foster IDL, Rowntree K (2017b) Are source groups always appropriate when sediment fingerprinting? The direct comparison of source and sediment samples as a methodological step. River Res Appl 33:553-1563

Raedeke AH, Rikoon JS (1997) Temporal and spatial dimensions of knowledge: implications for sustainable agriculture. Agric Hum Values 14:145-158

Reiffarth DG, Petticrew EL, Owens PN, Lobb DA (2016) Sources of variability in fatty acid (FA) biomarkers in the application of 
compound-specific stable isotopes (CSSIs) to soil and sediment fingerprinting and tracing: a review. Sci Total Environ 565:8-27

Reiffarth DG, Petticrew EL, Owens PN, Lobb DA (2019) Spatial differentiation of cultivated soils using compound-specific stable isotopes (CSSIs) in a temperate agricultural watershed in Manitoba, Canada. J Soils Sediments 19:3411-3426

Reynolds RL, Rosenbaum JG, Rapp J, Kerwin MW, Bradbury JP, Colman S, Adam D (2004) Record of late Pleistocene glaciation and deglaciation in the southern Cascade Range. I. Petrological evidence from lacustrine sediment in Upper Klamath Lake, southern Oregon. J Paleolimnol 31:217-233

Ribolzi O, Evrard O, Huon S, Rochelle-Newall E, Henri-des-Tureaux T, Silvera N, Thammahacksac C, Sengtaheuanghoung O (2016) Use of fallout radionuclides $\left({ }^{7} \mathrm{Be},{ }^{210} \mathrm{~Pb}\right)$ to estimate resuspension of Escherichia coli from streambed sediments during floods in a tropical montane catchment. Environ Sci Pollut Res 23:3427-3435

Rode M, Wade AJ, Cohen MJ, Hensley RT, Bowes MJ, Kirchner JW, Arhonditsis GB, Jordan P, Kronvang B, Halliday SJ, Skeffington RA, Rozemeijer JC, Aubert AH, Rinke K, Jomaa S (2016) Sensors in the stream: the high-frequency wave of the present. Environ Sci Technol 50:10297-10307

Rose DC, Mukherjee N, Simmons BI, Tew ER, Robertson RJ, Vadrot ABM, Doubleday R, Sutherland WJ (2017) Policy windows for the environment: tips for improving the uptake of scientific knowledge. Environ Sci Policy

Rose N (2002) Fly-ash particles. In: Last WM, Smol JP (eds) Tracking environmental change using lake sediments, Physical and geochemical methods, vol 2. Springer, Berlin, pp 319-349

Rose NL, Appleby PG (2005) Regional applications of lake sediment dating by spheroidal carbonaceous particle analysis I: United Kingdom. J Paleolimnol 34:349-361

Ruhala SS, Zarnetske JP (2017) Using in-situ optical sensors to study dissolved organic carbon dynamics of streams and watersheds: a review. Sci Total Environ 575:713-723

Ruxton BP (1968) Measures of the degree of chemical weathering of rocks. J Geol 76:518-527

Sahu S, Ajmal P, Bhangare R, Tiwari M, Pandit G (2014) Natural radioactivity assessment of a phosphate fertilizer plant area. J Radiat Res Appl Sci 7:123-128

Saitoh Y, Tamura T, Kodama Y, Nakano T (2011) Strontium and neodymium isotopic signatures indicate the provenance and depositional process of loams intercalated in coastal dune sand, western Japan. Sediment Geol 236:272-278

Sawakuchi AO, Mendes VR, Pupim FN, Mineli TD, Ribeiro LMAL, Zular A, Guedes CCF, Giannini PCF, Nogueira L, Sallun Filho W (2016) Optically stimulated luminescence and isothermal thermoluminescence dating of high sensitivity and well bleached quartz from Brazilian sediments: from Late Holocene to beyond the Quaternary? Braz J Geol 46:209-226

Sayyed M (2014) Lithological control on the mobility of elements during chemical weathering. Comun Geol 101:63-69

Schillereff DN, Chiverrell RC, Macdonald N, Hooke JM (2014) Flood stratigraphies in lake sediments: a review. Earth-Sci Rev 135:17-37

Schottler SP, Engstrom DR (2006) A chronological assessment of Lake Okeechobee (Florida) sediments using multiple dating markers. J Paleolimnol 36:19-36

Sellier V, Navratil O, Laceby JP, Allenbach M, Lefèvre I, Evrard O (2020) Investigating the use of fallout and geogenic radionuclides as potential tracing properties to quantify the sources of suspended sediment in a mining catchment in New Caledonia, South Pacific. J Soils Sediments 20:1112-1128

Seymour M (2019) Rapid progression and future of environmental DNA research. Commun Biol 2:80

Shao J, Yang S, Li C (2012) Chemical indices (CIA and WIP) as proxies for integrated chemical weathering in China: inferences from analysis of fluvial sediments. Sediment Geol 265-266:110-120
Silins U, Stone M, Emelko MB, Bladon KD (2009) Sediment production following severe wildfire and post-fire salvage logging in the Rocky Mountain headwaters of the Oldman River Basin, Alberta. Catena 79:189-197

Silins U, Bladon KD, Kelly EN, Esch E, Spence JR, Stone M, Emelko MB, Boon S, Wagner MJ, Williams CHS, Tichkowsky I (2014) Five-year legacy of wildfire and salvage logging impacts on nutrient runoff and aquatic plant, invertebrate, and fish productivity. Ecohydrology 7:1508-1523

Singh B, Roy SK, Sharma KP, Goswami TK (1998) Role of acidity of pillared inter-layered clay (PILC) for the synthesis of pyridine bases. J Chem Technol Biotechnol 71:246-252

Skalak K, Pizzuto J (2010) The distribution and residence time of suspended sediment stored within the channel margins of a gravelbed bedrock river. Earth Surf Process Landf 35:435-446

Smith HG, Blake WH (2014) Sediment fingerprinting in agricultural catchments: a critical re-examination of source discrimination and data corrections. Geomorphology 204:177-191

Smith BJ, Srinivasan S, Gomez-Heras M, Basheer PAM, Viles HA (2011a) Near-surface temperature cycling of stone and its implications for scales of surface deterioration. Geomorphology 130:76-82

Smith HG, Sheridan GJ, Lane PNJ, Nyman P, Haydon S (2011b) Wildfire effects on water quality in forest catchments: a review with implications for water supply. J Hydrol 396:170-192

Smith HG, Blake WH, Owens PN (2012) Application of sediment tracers to discriminate sediment sources following wildfire. In: Stone M, Collins A, Thoms M (eds) Wildfire and water quality: processes, impacts and challenges. IAHS Publ 354, IAHS Press, Wallingford, pp 81-89

Smith HG, Blake WH, Owens PN (2013a) Discriminating fine sediment sources and the application of sediment tracers in burned catchments: a review. Hydrol Process 27:943-958

Smith JA, Mazumder D, Suthers IM, Taylor MD (2013b) To fit or not to fit: evaluating stable isotope mixing models using simulated mixing polygons. Methods Ecol Evol 4:612-618

Smith DB, Cannon WF, Woodruff LG, Federico S, Ellefsen KJ (2014) Geochemical and mineralogical maps for soils of the contiguous United States. USGS open-file report no 2014-1082. United States Geological Survey, Reston

Smith HG, Karam DS, Lennard AT (2018) Evaluating tracer selection for catchment sediment fingerprinting. J Soils Sediments 18:3005-3019

Sobczak WV, Raymond PA (2015) Watershed hydrology and dissolved organic matter export across time scales: minute to millennium. Freshw Sci 34:392-398

Stock BC, Jackson AL, Ward EJ, Parnell AC, Phillips DL, Semmens BX (2018) Analyzing mixing systems using a new generation of Bayesian tracer mixing models. PeerJ 6:e5096

Stone M, Emelko MB, Droppo IG, Silins U (2011) Biostabilization and erodibility of cohesive sediment deposits in wildfire-affected streams. Water Res 45:521-534

Stone M, Collins AL, Silins U, Emelko MB, Zhang YS (2014) The use of composite fingerprints to quantify sediment sources in a wildfire impacted landscape, Alberta, Canada. Sci Total Environ 473-474: $642-650$

Stromqvist J, Collins AL, Davison PS, Lord EI (2008) PSYCHIC - a process-based model of phosphorus and sediment transfers within agricultural catchments. Part 2. A preliminary evaluation. J Hydrol 350:303-316

Sueoka T, Lee I, Muramatsu M, Imamura S (1985) Geomechanical properties and engineering classification for decomposed granite soils in Kaduna district, Nigeria. Proceedings of the First International Conference on Geomechanics in Tropical Lateritic and Saprolitic Soils, Brasilia, pp 175-186

Svensson JM, Enrich-Prast A, Leonardson L (2001) Nitrification and denitrification in a eutrophic lake sediment bioturbated by oligochaetes. Aquat Microb Ecol 23:177-186 
Tang Q, Fu B, Wen A, Zhang X, He X, Collins AL (2019) Fingerprinting the sources of water-mobilized sediment threatening agricultural and water resource sustainability: progress, challenges and prospects in China. Sci China Earth Sci 62:2017-2030

Taylor SR, McLennan SM (1985) The continental crust: its composition and evolution. Blackwell Scientific Publications, Oxford 312 pp

Telfer MW, Gholami H, Hesse PP, Fisher A, Hartley R (2020) Testing models of linear dune formation by provenance analysis with composite sediment fingerprints. Geomorphology 364:107208

Thomas PJ, Juyal N, Kale VS, Singhvi AK (2007) Luminescence chronology of late Holocene extreme hydrological events in the upper Penner River basin, South India. J Quat Sci 22:747-753

Tiecher T, Ramon R, Laceby JP, Evrard O, Minella JPG (2019) Potential of phosphorus fractions to trace sediment sources in a rural catchment of Southern Brazil: comparison with the conventional approach based on elemental geochemistry. Geoderma 337:10671076

Tsouvalis J, Seymour S, Watkins C (2000) Exploring knowledge-cultures: precision farming, yield mapping, and the expert-farmer interface. Environ Plann A 32:909-924

Tůmová Š, Hrubešová D, Vorm P, Hošek M, Grygar TM (2019) Common flaws in the analysis of river sediments polluted by risk elements and how to avoid them: case study in the Ploučnice River system, Czech Republic. J Soils Sediments 19:2020-2033

Turner A, Taylor A (2018) On site determination of trace metals in estuarine sediments by field-portable-XRF. Talanta 190:498-506

Turner BL, Mahieu N, Condron LM (2003) The phosphorus composition of temperate pasture soils determined by $\mathrm{NaOH}-\mathrm{EDTA}$ extraction and solution P-31 NMR spectroscopy. Org Geochem 34:1199-1210

Uber M, Legout C, Nord G, Crouzet C, Demory F, Poulenard J (2019) Comparing alternative tracing measurements and mixing models to fingerprint suspended sediment sources in a mesoscale Mediterranean catchment. J Soils Sediments 19:3255-3273

Upadhayay HR, Bode S, Griepentrog M, Huygens D, Bajracharya RM, Blake WH, Dercon G, Mabit L, Gibbs M, Semmens BX, Stock BC, Cornelis W, Boeckx P (2017) Methodological perspectives on the application of compound-specific stable isotope fingerprinting for sediment source apportionment. J Soils Sediments 17:1537-1553

Upadhayay HR, Bode S, Griepentrog M, Bajracharya RM, Blake W, Cornelis W, Boeckx P (2018a) Isotope mixing models require individual isotopic tracer content for correct quantification of sediment source contributions. Hydrol Process 32:981-989

Upadhayay HR, Griepentrog M, Bodé S, Bajracharya RM, Cornelis W, Collins AL, Boeckx P (2020a) Catchment-wide variations and biogeochemical time lags in soil fatty acid carbon isotope composition for different land uses: implications for sediment source classification. Org Geochem 146:104048

Upadhayay HR, Lamichhane S, Bajracharya RM, Cornelis W, Collins AL, Boeckx P (2020b) Sensitivity of source apportionment predicted by a Bayesian tracer mixing model to the inclusion of a sediment connectivity index as an informative prior: illustration using the Kharka catchment (Nepal). Sci Total Environ 713:136703

Upadhayay HR, Smith HG, Griepentrog M, Bode S, Bajracharya RM, Blake W, Cornelis W, Boeckx P (2018b) Community managed forests dominate the catchment sediment cascade in the mid-hills of Nepal: a compound-specific stable isotope analysis. Sci Total Environ 637:306-317

Vale SS, Dymond JR (2020) Interpreting nested storm event suspended sediment-discharge hysteresis relationships at large catchment scales. Hydrol Process 34:420-440

Vale SS, Fuller IC, Procter JN, Basher LR, Smith IE (2016) Characterization and quantification of suspended sediment sources to the Manawatu River, New Zealand. Sci Total Environ 543:171-186

Van Exem A, Debret M, Copard Y, Vannière B, Sabatier P, Marcotte S, Laignel B, Reyss J-L, Desmet M (2018) Hyperspectral core logging for fire reconstruction studies. J Paleolimnol 59:297-308
Van Metre PC, Horowitz AJ (2013) An 80-year record of sediment quality in the lower Mississippi River. Hydrol Process 27:2438-2448

Viles HA, Goudie AS (2004) Biofilms and case hardening on sandstones from Al-Quwayra, Jordan. Earth Surf Process Landf 29:1473-1485

Vogel D (1975) Precambrian weathering in acid metavolcanic rocks from the Superior Province, Villebon Township, South-central Quebec. Can J Earth Sci 12:2080-2085

Wall G, Wilding L (1976) Mineralogy and related parameters of fluvial suspended sediments in Northwestern Ohio 1. J Environ Qual 5:168-173

Wallbrink P, Murray A (1993) Use of fallout radionuclides as indicators of erosion processes. Hydrol Process 7:297-304

Wallbrink PJ, Murray AS, Olley J, Olive LJ (1998) Determining sources and transit times of suspended sediment in the Murrumbidgee River, New South Wales, Australia, using fallout ${ }^{137} \mathrm{Cs}$ and ${ }^{210} \mathrm{~Pb}$. Water Resour Res 4:879-887

Wallbrink PJ, Murray AS, Olley JM (1999) Relating suspended sediment to its original soil depth using fallout radionuclides. Soil Sci Soc Am J 63:369-378

Walling D, Collins A (2000) Integrated assessment of catchment suspended sediment budgets: a technical manual. Unpublished University of Exeter report, Exeter, $168 \mathrm{pp}$

Walling D, Foster I (2016) Using environmental radionuclides, mineral magnetism and sediment geochemistry for tracing and dating fine fluvial sediments. In: Kondolf GM, Piégay H (eds) Tools in fluvial geomorphology. Wiley, Chichester, pp 181-209

Walling D, Peart M, Oldfield F, Thompson R (1979) Suspended sediment sources identified by magnetic measurements. Nature 281:110

Walling DE, Woodward JC (1992) Use of radiometric fingerprints to derive information on suspended sediment sources. In: Bogen J, Walling DE, Day T (eds) Erosion and sediment transport monitoring programmes in river basins, vol 210. IAHS Publ, pp 153-164

Walling DE (2005) Tracing suspended sediment sources in catchments and river systems. Sci Total Environ 344:159-184

Walling DE (2013a) Beryllium-7: the Cinderella of fallout radionuclide sediment tracers? Hydrol Process 27:830-844

Walling DE (2013b) The evolution of sediment source fingerprinting investigations in fluvial systems. J Soils Sediments 13:1658-1675

Walling DE, Collins AL, Sichingabula HM, Leeks GJL (2001) Integrated assessment of catchment suspended sediment budgets: a Zambian example. Land Degrad Dev 12:387-415

Walling DE, Collins AL, Jones PA, Leeks GJL, Old G (2006) Establishing fine-grained sediment budgets for the Pang and Lambourn LOCAR catchments, UK. J Hydrol 330:126-141

Walling DE, Collins AL, McMellin GK (2003) A reconnaissance survey of the source of interstitial fine sediment recovered from salmonid spawning gravels in England and Wales. Hydrobiologia 497:91-108

Walling DE, Woodward JC (1995) Tracing sources of suspended sediment in river basins - a case-study of the River Culm, Devon, UK. Mar Freshw Res 46:327-336

Walling DE, Woodward JC, Nicholas AP (1993) A multi-parameter approach to fingerprinting suspended-sediment sources. In: Peters NE, Hoehn E, Leibundgut C, Tase N, Walling DE (eds) Tracers in hydrology. IAHS Publication No. 215, IAHS Press, Wallingford, pp 329-338

Wang G, Li J, Ravi S, Van Pelt SR, Costa PJM, Dukes D (2017) Tracer techniques in aeolian research: approaches, applications, and challenges. Earth-Sci Rev 170:1-16

Weiss T, Siegesmund S, Kirchner D, Sippel J (2004) Insolation weathering and hygric dilatation: two competitive factors in stone degradation. Environ Geol 46:402-413

Wilkinson SN, Prosser IP, Rustomji P, Read AM (2009) Modelling and testing spatially distributed sediment budgets to relate erosion processes to sediment yields. Environ Model Software 24:489-501

Wilkinson SN, Hancock GJ, Bartley R, Hawdon AA, Keen RJ (2013) Using sediment tracing to assess processes and spatial patterns of erosion in grazed rangelands, Burdekin River basin, Australia. Agric Ecosyst Environ 180:90-102 
Wilkinson SN, Olley JM, Furuichi T, Buton J, Kinsey-Henderson AE (2015) Sediment source tracing with stratified sampling and weightings based on spatial gradients in soil erosion. J Soils Sediments 15:2038-2051

Writer JH, Hohner A, Oropeza J, Schmidt A, Cawley K, Rosario-Ortiz FL (2014) Water treatment implications after the High Park Wildfire in Colorado. J Am Water Works Assoc 106:E189-E199

Wu L, He Y, Ma XY (2020) Can soil conservation practices reshape the relationship between sediment yield and slope gradient? Ecol Eng 142:105630

Yang XP, Zhang F, Fu XD, Wang XM (2008) Oxygen isotopic compositions of quartz in the sand seas and sandy lands of northern China and their implications for understanding the provenances of aeolian sands. Geomorphology 102:278-285
Yu M, Eglinton TI, Haghipour N, Montlucon DB, Wacker L, Wang ZC, Jin GE, Zhao MX (2019) Molecular isotopic insights into hydrodynamic controls on fluvial suspended particulate organic matter transport. Geochim Cosmochim Acta 262:78-91

Zhao Y, Gao GL, Zhang Y, Ding GD, Zhou JX, Chen YX, Zhou QZ (2020) Aeolian sediment fingerprinting in the Cuona Lake Section along the Qinghai-Tibetan Railway. J Clean Prod 261:121233

Zou YH, Wang LX, Christensen ER (2015) Problems in the fingerprints based polycyclic aromatic hydrocarbons source apportionment analysis and a practical solution. Environ Pollut 205:394-402

Publisher's note Springer Nature remains neutral with regard to jurisdictional claims in published maps and institutional affiliations.

\section{Affiliations}

Adrian L. Collins ${ }^{1}$ (ID $\cdot$ Martin Blackwell ${ }^{1} \cdot$ Pascal Boeckx $^{2} \cdot$ Charlotte-Anne Chivers $^{1,3} \cdot$ Monica Emelko ${ }^{4}$. Olivier Evrard ${ }^{5} \cdot$ Ian Foster ${ }^{6}$. Allen Gellis ${ }^{7} \cdot$ Hamid Gholami $^{8}$. Steve Granger ${ }^{1}$ • Paul Harris ${ }^{1} \cdot$ Arthur J. Horowitz $^{9}$. J. Patrick Laceby ${ }^{10} \cdot$ Nuria Martinez-Carreras $^{11} \cdot$ Jean Minella ${ }^{12} \cdot$ Lisa Mol $^{13} \cdot$ Kazem Nosrati $^{14} \cdot$ Simon Pulley $^{1}$. Uldis Silins ${ }^{15} \cdot$ Yuri Jacques da Silva ${ }^{16} \cdot$ Micheal Stone $^{17} \cdot$ Tales Tiecher $^{18} \cdot$ Hari Ram Upadhayay $^{1} \cdot$ Yusheng Zhang $^{1}$

1 Sustainable Agriculture Sciences, Rothamsted Research, North Wyke, Okehampton, Devon EX20 2SB, UK

2 Isotope Bioscience Laboratory-ISOFYS, Ghent University, Coupure Links 653, 9000 Ghent, Belgium

3 Centre for Rural Policy Research, University of Exeter, Lazenby House, Pennsylvania Road, Exeter EX4 4PJ, UK

4 Department of Civil and Environmental Engineering, University of Waterloo, Waterloo, Ontario, Canada

5 Laboratoire des Sciences du Climat et de l'Environnement (LSCE/ IPSL), Unité Mixte de Recherche 8212 (CEA/CNRS/UVSQ), Université Paris-Saclay, 91191 Gif-sur-Yvette Cedex, France

6 Environmental \& Geographical Sciences, Learning Hub (Room 101), University of Northampton, University Drive, Northampton NN1 5PH, UK

7 U.S. Geological Survey, 5522 Research Park Drive, Baltimore, MD 21228, USA

8 Department of Natural Resources Engineering, University of Hormozgan, Bandar-Abbas, Hormozgan, Iran

9 South Atlantic Water Science Center, U.S. Geological Survey, Atlanta, GA, USA
10 Alberta Environment and Parks, 3535 Research Rd NW, Calgary, Alberta T2L 2K8, Canada

11 Luxembourg Institute of Science and Technology (LIST), Catchment and Eco-hydrology Research Group (CAT), L4422 Belvaux, Luxembourg

12 Department of Soil Science, Federal University of Santa Maria, Roraima Ave. 1000, Santa Maria, RS 97105-900, Brazil

13 Department of Geography and Environmental Management, University of the West of England, Bristol, UK

14 Department of Physical Geography, School of Earth Sciences, Shahid Beheshti University, Tehran 1983969411, Iran

15 Department of Renewable Resources, University of Alberta, Edmonton, Alberta T6G 2I7, Canada

16 Agronomy Department, Federal University of Piaui (UFPI), Planalto Horizonte, Bom Jesus, PI 64900-000, Brazil

17 Department of Geography and Environmental Management, Faculty of Environment, University of Waterloo, EV1 Room 112, Waterloo, Canada

18 Department of Soil Science, Federal University of Rio Grande do Sul, Bento Gonçalves Ave. 7712, Porto Alegre, RS 91540-000, Brazil 